UNIVERSIDADE DE BRASÍLIA

FACULDADE DE TECNOLOGIA DEPARTAMENTO DE ENGENHARIA CIVIL E AMBIENTAL

\title{
ANÁLISE DOS PREJUÍZOS FINANCEIROS DA INDÚSTRIA BRASILEIRA DE AVIAÇÃO CIVIL: A INFLUÊNCIA DAS FORÇAS COMPETITIVAS DE PORTER
} ROBERT RAMON DE CARVALHO SOUSA

ORIENTADOR: CARLOS HENRIQUE MARQUES DA ROCHA DISSERTAÇÃO DE MESTRADO EM TRANSPORTES PUBLICAÇÃO: T.DM - 005/2016 BRASÍLIA/DF: MARÇO - 2016 
UNIVERSIDADE DE BRASÍLIA

FACULDADE DE TECNOLOGIA

DEPARTAMENTO DE ENGENHARIA CIVIL E AMBIENTAL

ANÁLISE DOS PREJUÍZOS FINANCEIROS DA INDÚSTRIA BRASILEIRA DE AVIAÇÃO CIVIL: INFLUÊNCIA DAS FORÇAS

COMPETITIVAS DE PORTER

ROBERT RAMON DE CARVALHO SOUSA

DISSERTAÇÃO SUBMETIDA AO DEPARTAMENTO DE ENGENHARIA CIVIL E AMBIENTAL DA FACULDADE DE TECNOLOGIA DA UNIVERSIDADE DE BRASÍLIA COMO PARTE DOS REQUISÍTOS NECESSÁRIOS PARA A OBTENÇÃO DO GRAU DE MESTRE EM TRANSPORTES

APROVADA POR:

Prof. Carlos Henrique Marques da Rocha, PhD (ENC-UnB) (Orientador)

Prof. Sérgio Ronaldo Granemann, Dr. (ENC-UnB)

(Examinador Interno)

Prof. João Mello da Silva, PhD (FT-UnB)

(Examinador Externo)

BRASÍLIA/DF, 23 DE MARÇO DE 2016 


\section{FICHA CATALOGRÁFICA}

\section{SOUSA, ROBERT RAMON DE CARVALHO.}

Análise dos Prejuízos Financeiros da Indústria brasileira de Aviação Civil: Influência das Forças Competitivas de Porter [Distrito Federal] 2016.

99p., 210 x $297 \mathrm{~mm}$ (ENC/FT/UnB, Mestre, Transportes, 2016).

Dissertação de Mestrado - Universidade de Brasília. Faculdade de Tecnologia.

Departamento de Engenharia Civil e Ambiental.

1. Análise dos Infortúnios financeiros

2.Competição na Indústria

3. Recorrentes Prejuízos

4.Risco de rentabilidade

I. ENC/FT/UnB

II. Título (Mestre)

\section{REFERÊNCIA BIBLIOGRÁFICA}

SOUSA, R. R. de C. (2016). Análise dos Prejuízos Financeiros da Indústria brasileira de Aviação Civil: Influência das Forças Competitivas de Porter. Dissertação de Mestrado em Transportes, Publicação T. DM-005/2016, Departamento de Engenharia Civil e Ambiental, Universidade de Brasília, Brasília, DF, 99p.

\section{CESSÃO DE DIREITOS}

AUTOR: Robert Ramon de Carvalho Sousa.

TÍTULO: Análise dos Prejuízos Financeiros da Indústria brasileira de Aviação Civil: Influência das Forças Competitivas de Porter.

GRAU: Mestre

ANO: 2016

É concedida à Universidade de Brasília permissão para reproduzir cópias desta dissertação de mestrado e para emprestar ou vender tais cópias somente para propósitos acadêmicos e científicos. $\mathrm{O}$ autor reserva outros direitos de publicação e nenhuma parte dessa dissertação de mestrado pode ser reproduzida sem autorização por escrito do autor.

Robert Ramon de Carvalho Sousa Anexo SG-12, $1^{\circ}$ andar UnB - Asa Norte 70.910-900 Brasília - DF - Brasil. 


\section{RESUMO}

Recentemente, adotou-se o incentivo à competição como estratégia de regulação da indústria brasileira de transporte aéreo de passageiros. O ambiente de negócios, antes fortemente regulado pelo governo brasileiro passou a apresentar características de livre mercado. Os fatores positivos resultantes da competição foram a expansão da oferta do serviço e a redução das tarifas aeroportuárias. Com isso, uma maior parcela da população brasileira passou a ter acesso ao serviço. No entanto, as companhias aéreas incorreram em prejuízos financeiros anuais bilionários no período 2011-2013. Para investigar os fatores que impactam negativamente a rentabilidade das companhias aéreas brasileiras, recorreu-se à Teoria da Organização Industrial. A Teoria da Organização Industrial afirma que o potencial de atratividade de uma indústria é explicado por seus fatores estruturais. Entre os modelos existentes, Porter (1979) elaborou um arcabouço teórico que propicia diagnosticar a influência dos fatores estruturais de uma indústria na sua rentabilidade média, denominado "Cinco Forças Competitivas". O modelo é composto por cinco forças: ameaça de novos participantes, ameaça de substitutos, poder dos compradores, poder dos fornecedores e a concorrência interna da indústria. Quanto mais intensas forem estas cinco forças juntas, menor tende a ser a lucratividade industrial. Os resultados indicaram que a indústria brasileira de transporte aéreo de passageiros apresenta elevadas barreiras de entradas caracterizadas pelo alto capital exigido. O poder dos fornecedores é forte, devido ao pequeno o número de empresas ofertantes de aeronaves e combustível. O poder dos compradores é fraco, pois, eles são apenas tomadores de preços. A concorrência interna da indústria é forte porque as companhias aéreas têm intensificado a competição com vistas a reduzir os déficits. 


\begin{abstract}
Recently adopted the encouraging competition as regulatory strategy of the Brazilian industry of air transport passengers. The business environment before heavily regulated by the Brazilian government began to introduce free market characteristics. The positive factors resulting from competition were the expansion of the service offering and reducing airport fees. As a result, a greater portion of the population now has access to the service. However, the airlines incurred rude annual financial losses in the period 2011-2013. To investigate the factors that negatively affect the profitability of Brazilian airlines we resorted to the theory of industrial organization. Such theory among other things states that the potential attractiveness of an industry can be explained by its structural factors. We highlight Porter's model of five forces (Porter, 1979). The five forces are threat of new entrants, threat of substitutes, buyer power, power of suppliers and domestic competition in the industry. The more intense are these five joints, forces tend to be lower the industry profitability. Our results indicated that the Brazilian industry of air passengers has high barriers to entry characterized by high capital requirements. The power of suppliers is strong because the small number of suppliers companies of aircraft and fuel. The power of buyers is weak because they are just price takers. The industry's domestic competition is strong because airlines have intensified the competition in order to reduce their deficits.
\end{abstract}




\section{SUMÁRIO}

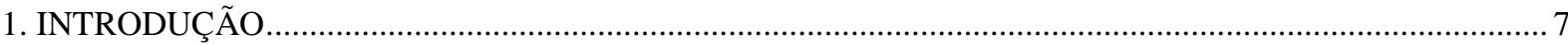

1.2 PROBLEMA

1.3 HIPÓTESE

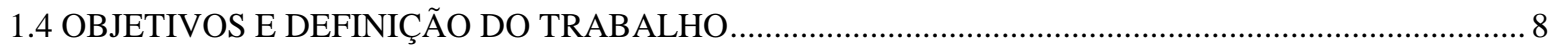

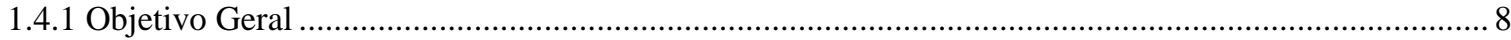

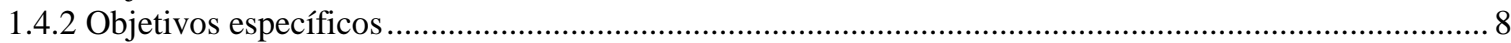

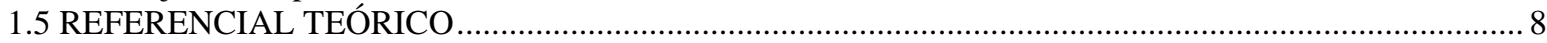

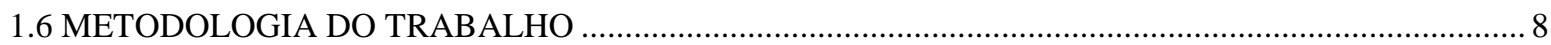

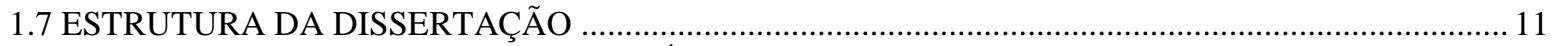

2. PANORAMA GERAL DO TRANSPORTE AÉREO INTERNACIONAL E NACIONAL DE

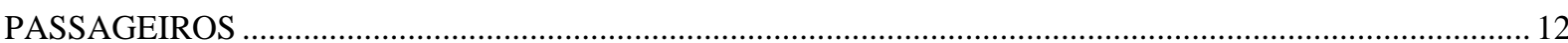

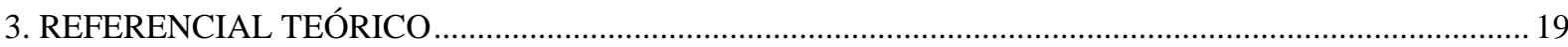

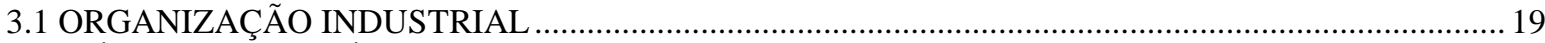

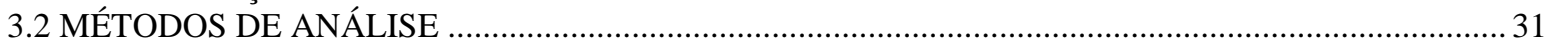

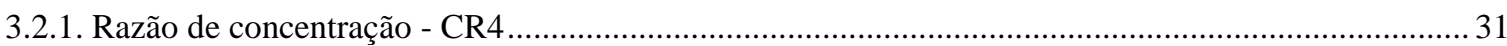

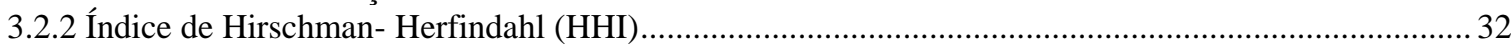

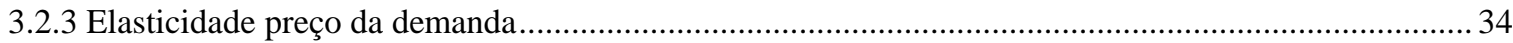

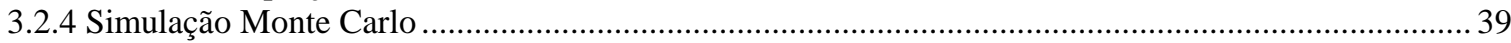

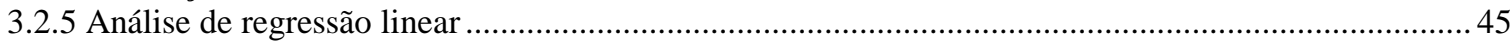

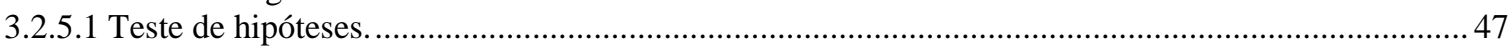

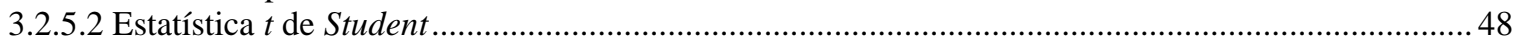

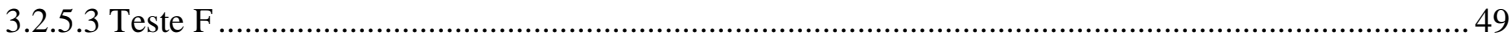

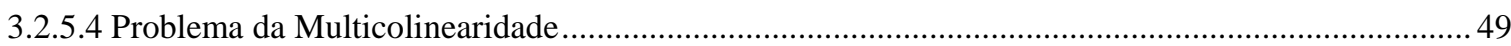

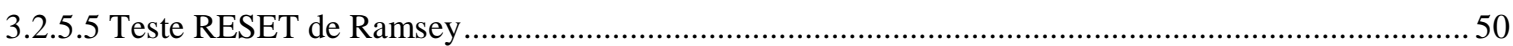

4. APLICAÇÃO DO MODELO DE PORTER (1979) NA ANÁLISE DOS INFORTÚNIOS FINANCEIROS

DA INDÚSTRIA BRASILEIRA DE TRANSPORTE AÉREO DE PASSAGEIROS …....................................53

4.1 Agentes da indústria brasileira de transporte aéreo doméstico de passageiros .............................................53

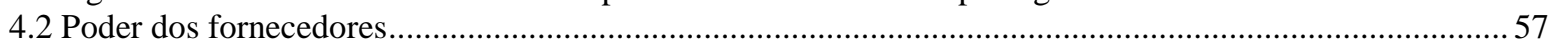

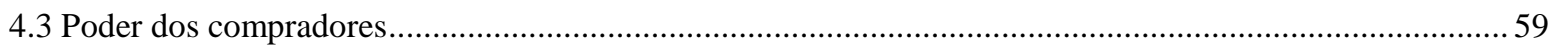

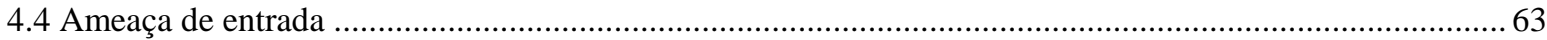

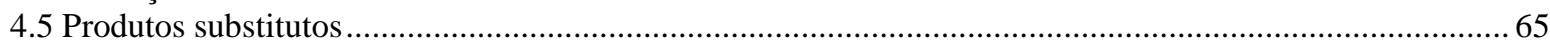

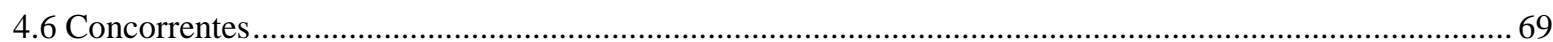

4.7 A construção dos cenários ................................................................................................................................... 77

5. CONCLUSÃO

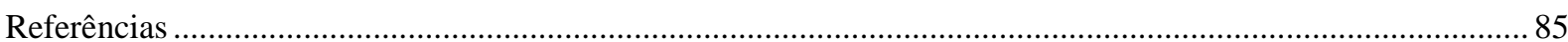




\section{INTRODUÇÃO}

O Brasil apresenta dimensões continentais com 8,51 milhões de km2. Os deslocamentos rápidos e seguros de pessoas interestados dependem fortemente do transporte aéreo. A taxa média anual de crescimento do número de passageiros pagos no mercado doméstico entre 2011 e 2013 foi de 4,7\%, bem acima da taxa de crescimento do PIB (Produto Interno Bruto) brasileiro neste período.

Recentemente, houve uma mudança na regulamentação do setor motivada pela busca de melhorias de acesso ao serviço por parte dos consumidores. O setor deixou de ser regulado e, atualmente, apresenta uma quase desregulamentação. Em face desta mudança emergiu uma característica que diferencia o transporte aéreo dos demais setores de transportes no Brasil, há uma tendência de concorrência entre as empresas que compõem a indústria. Tal dinâmica tem refletido nos resultados financeiros.

Visando analisar a influência da regulação do setor de transporte aéreo na competição, Busto, Turolla e Oliveira (2006) constataram que a política de flexibilização adotada foi uma medida considerada bem-sucedida, em decorrência desta política houve um aumento de $136 \%$ nos descontos das tarifas aéreas, uma redução de $44 \%$ no tempo entre voos e uma redução de $34 \%$ no índice de concentração (HHI) entre os períodos pré-liberalização (jan/97-dez/97) e pósliberalização (jan/98-out/01) na ponte aérea Rio de Janeiro-São Paulo.

No entanto, vem apresentando recorrentes problemas financeiros, uma hipótese a respeito das razões que causam este efeito é a ocorrência de guerras de preços. Nascimento, Vieira e Braga (2011) se propuseram a investigar possíveis padrões de guerras de preço e formação de conluio das companhias aéreas que operam no trecho Rio de Janeiro-São Paulo (GOL e TAM), visando estimar as condições que facilitariam os dois fenômenos com base em dados referentes ao período de 2002 a 2010. Os resultados mostraram que a GOL tem maior probabilidade de entrar em guerra de preços do que em conluio devido à sua estratégia de baixo custo no mercado, ao contrário da TAM.

Todos estes fatores estão impulsionando a indústria para uma situação de difícil sustentação, resultando em déficits expressivos nos anos de 2011 a 2013. O déficit apurado em 2011 foi de $\mathrm{R}$ \$ 1, 6 bilhão, o de 2012 foi de $\mathrm{R}$ \$ 3,5 bilhões e o de 2013 foi de $\mathrm{R}$ \$ 2,4 bilhões. Registre-se que o pior resultado financeiro em 2013 foi obtido pela TAM, R \$ 1,7 bilhão (ANAC, 2013: p. 161).

Para avaliar as relações existentes entre a estrutura de uma indústria e seu potencial de rentabilidade, Porter (1979) elaborou um modelo denominado "Cinco Forças Competitivas". Por meio deste modelo Porter (1979) explica que há indústrias que têm naturalmente um potencial de rentabilidade maior do que outras, isso ocorre devido à estrutura industrial ser influenciada pelo poder de negociação dos fornecedores, poder de negociação dos compradores, a ameaça de produtos substitutos, a ameaça de entrantes na indústria e a força competitiva central é a competição.

O modelo de Porter (1979) evoluiu com as contribuições posteriores de Guemawat (2001) e Slater e Olson (2002). Os principais fatores complementares foram a influência dos chamados complementadores, bem como a inclusão explícita do risco de rentabilidade. 
Este é o primeiro estudo brasileiro a analisar o desempenho financeiro da indústria brasileira doméstica de transporte aéreo de passageiros à luz do modelo de Porter (1979), relacionando as forças competitivas ao resultado financeiro da indústria por variáveis representativas.

\subsection{PROBLEMA}

Os recorrentes déficits financeiros da indústria brasileira de transporte aéreo de passageiros podem ser explicados por algum modelo teórico?

\subsection{HIPÓTESE}

O desempenho financeiro da indústria nacional de transporte aéreo de passageiros pode ser entendido por meio das forças competitivas de Porter.

\subsection{OBJETIVOS E DEFINIÇÃO DO TRABALHO}

\subsubsection{Objetivo Geral}

Verificar se o desempenho financeiro da indústria nacional de transporte aéreo de passageiros pode ser explicado pelo modelo teórico de forças competitivas de Porter.

\subsubsection{Objetivos específicos}

Os objetivos específicos são:

- Identificar os stakeholders da indústria e descrever a interação entre eles.

- Analisar as cinco forças competitivas da indústria brasileira de transporte aéreo de passageiros à luz da contribuição teórica elaborada por Porter (1979).

- Analisar a relação existente entre algumas variáveis que representam as forças competitivas de Porter e o desempenho financeiro da indústria nacional de transporte aéreo de passageiros.

\subsection{REFERENCIAL TEÓRICO}

Esta pesquisa está alicerçada na teoria da organização industrial, em particular, no modelo de cinco Forças Competitivas de Porter (1979).

\subsection{METODOLOGIA DO TRABALHO}

Esta pesquisa tem caráter exploratório, o método de pesquisa adotado é o hipotético-dedutivo, pois parte de constatações teóricas para observar fenômenos particulares. Foram realizados os seis passos descritos a seguir.

1- Revisão da bibliografia - foi estudada a bibliografia referente à organização industrial por meio dos trabalhos disponível no banco de teses e dissertações da Capes. Considerando a relevância da contribuição teórica dada, o método escolhido foi o de "Cinco Forças Competitivas de Porter", conforme a figura 1.

2 - Identificação do Stakeholders - foram identificados os stakeholders por meio de pesquisa bibliográfica. Utilizou-se como suporte: estudos acadêmicos, notícias na imprensa e normativos técnicos que comprovam a relação das companhias aéreas com outros participantes da indústria. 
3 - Eleição das variáveis - buscou-se escolher variáveis capazes de refletir a relação das forças competitivas da indústria brasileira de aviação civil com o seu resultado financeiro anual da indústria.

4 - Coleta de dados - os dados foram extraídos do Anuário do Transporte Aéreo disponíveis no site da Agência Nacional de Aviação Civil - ANAC desde o ano de 2002. As análises financeiras foram embasadas pela Demonstração de Resultado do Exercício - DRE do setor de transporte aéreo brasileiro.

5- Escolha dos métodos de análise quantitativa - os métodos quantitativos foram escolhidos com base em pesquisa bibliográfica, com isso foi possível selecionar àqueles com maior potencial de extração de informações.

6 - Análise dos resultados - análise dos resultados foi feita com base nos resultados obtidos após a aplicação dos métodos escolhidos aos dados extraídos no Anuário do Transporte Aéreo-ANAC. 
Figura 1: Metodologia da dissertação.

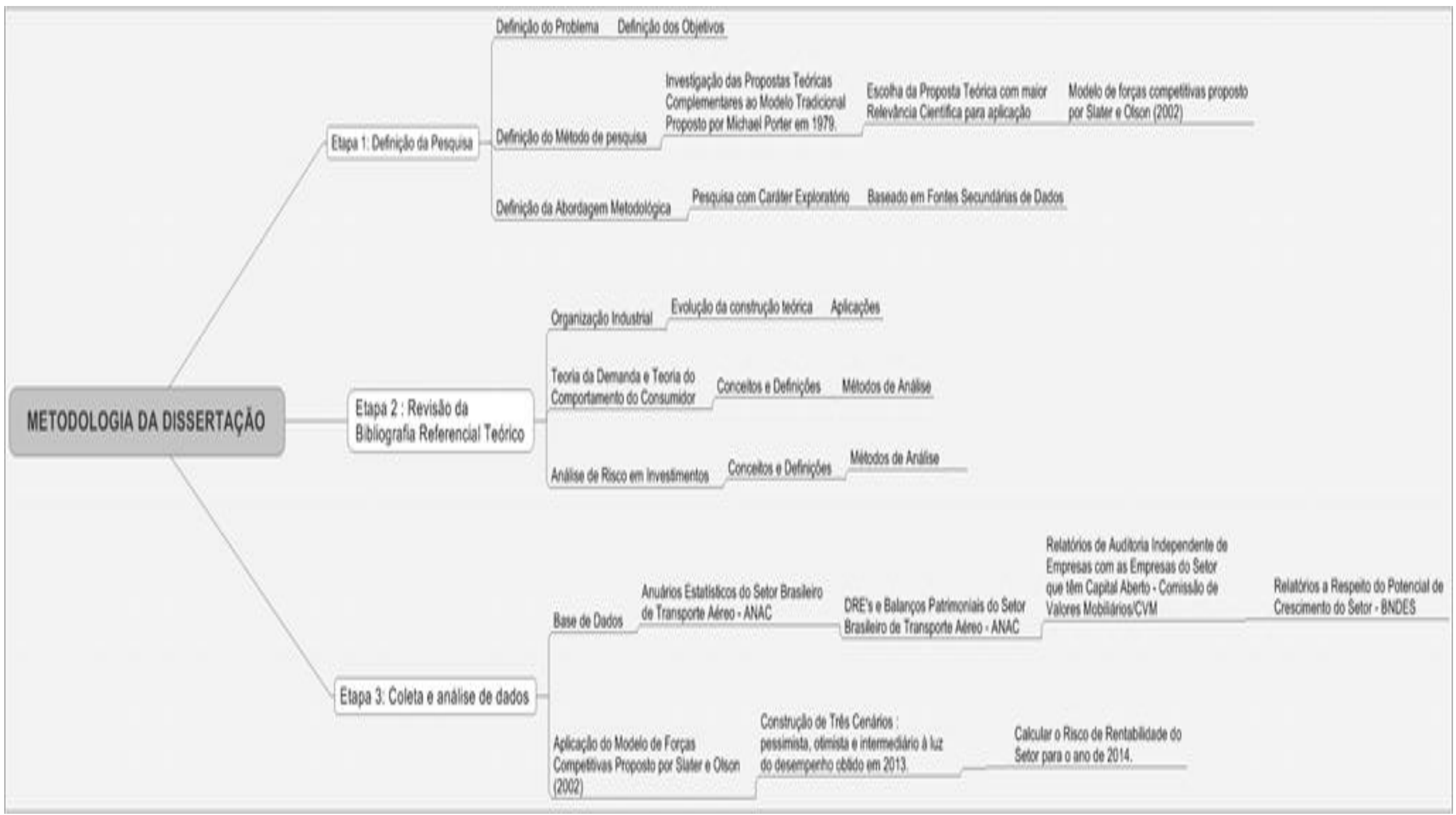




\subsection{ESTRUTURA DA DISSERTAÇÃO}

O capítulo 2 apresenta a base teórica da pesquisa. O capítulo 3 desta dissertação traz um panorama do transporte aéreo brasileiro. O capítulo 4 analisa a indústria de aviação civil brasileira à luz do modelo de Porter (1979). O capítulo 5 conclui a dissertação. 


\section{PANORAMA GERAL DO TRANSPORTE AÉREO INTERNACIONAL E NACIONAL DE PASSAGEIROS}

Scharpenseel (2001) afirma que a aviação, tanto em nível nacional quanto internacional, foi tradicionalmente regulada em todo o mundo. A regulamentação da viação internacional surgiu a partir da Convenção de Paris de 1919, nesta houve um aceite de que os Estados Unidos tivessem direito soberano sobre o espaço aéreo acima do seu território. Sete governos diretamente envolvidos foram procurados visando uniformizar ações direcionadas à supressão da concorrência na indústria com o intuito de estabilizar a indústria e proteger os interesses financeiros das transportadoras individuais. Em meio às consequências catastróficas da Grande "Depressão" as agências reguladoras em todo o mundo passaram a permitir a concorrência controlada, ou seja, regulando para evitar práticas competitivas "desleais ou destrutivas". Em 1938, os EUA (Estados Unidos da América) estabeleceram que a autorização de acesso às rotas deveriam ser condicionadas a : prévia especificação das tarifas, garantia de práticas de segurança nas operações. Sendo permitida apenas a operação quando houvesse interesse público caso a companhia tivesse a capacidade de servir a rota solicitada sem causar nenhum dano financeiro.

Entre as décadas de 1920 e 1960, a economia brasileira passou por diversas transformações. A segunda grande guerra mundial e a construção de Brasília contribuíram para um crescimento expressivo do setor de transporte aéreo nacional.

A criação de várias empresas de grande porte, como Varig (1927), Vasp (1933), Lóide Aéreo Nacional (1947) e Transbrasil (1955), buscavam suprir a demanda por transporte aéreo que crescia em níveis intensos (Bielschowsky e Custódio, 2011).

A presença maciça de capital estrangeiro, principalmente americano e europeu além da forte atuação do estado brasileiro, culminou no rápido crescimento do setor e na mudança da composição do sistema de transportes nacional.

Com todas essas transformações, houve também uma espécie de consolidação do setor, que através das décadas foi se modificando incessantemente. Empresas quebraram, saíram do mercado, outras cresceram absurdamente, incorporaram companhias menores e marcaram para sempre o panorama brasileiro dos transportes de passageiros.

Desde o início da aviação, vários fatos importantes impactaram diretamente no transporte aéreo nacional, fazendo assim com que o setor se transformasse em um dos mais complexos da economia. Para que este estudo fique mais organizado, far-se-á uma linha do tempo com alguns dos fatores imprescindíveis para a compreensão da história do transporte aéreo de passageiros no Brasil.

- Década de 1920

Durante este período o Brasil adotava um modelo de crescimento econômico baseado na agropecuária voltada para a exportação. Produtos de baixo valor agregado que não exigiam mão de obra qualificada dominavam o cenário interno, driblando assim a crise econômica mundial (quebra da bolsa de Nova York, 1929). 
Segundo Bielschowsky e Custódio (2011), o modelo de crescimento voltado para fora fez aumentar a visibilidade do Brasil consideravelmente, atraindo assim, investimentos estrangeiros em setores como o de transporte de passageiros em suas mais diversas vertentes e no surgimento das primeiras companhias aéreas brasileiras.

As principais empresas criadas foram: Compagnie Générale Aéropostale (1921) (início das operações no Brasil), Condor Syndikat (1924), Cruzeiro (1927), Flex Linhas Aéreas (1927) e Varig (1927).

- Década de 1930

A década de 1930 foi marcada pela transição entre o modelo de crescimento voltado para fora e o voltado para dentro. Nos anos 30, a indústria cafeeira paulista entrou em colapso e a entrada de capital estrangeiro cessou devido à crise de 1929, exigindo assim a atuação mais forte do estado na economia (Cano, 2012).

Medidas de proteção ao mercado interno, bem como o investimento estatal na industrialização mantiveram o setor de aviação aquecido, mantendo assim a criação de novas empresas e o aumento constante do número de viagens.

As principais empresas criadas foram: Panair (1930), Aerolloyd Iguassu (1933) e Vasp (1933), sendo que a Vasp era de propriedade do governo do estado de São Paulo.

- Década de 1940

Como o agravamento da segunda guerra mundial, a presença do estado na economia se intensificou. A aproximação do Brasil com os Estados Unidos trouxe uma série de benefícios para o Brasil, que também ganhou pelo encarecimento (aumento de preços) das commodities, dado pela intensidade da guerra (CPDOC-FGV, 2014).

Os Estados Unidos da América apresentaram na Convenção Internacional sobre Aviação em 1944 uma proposta de liberalização do espaço aéreo em nível mundial, não obteve êxito uma vez que o mundo vivia um cenário de guerra e quase todos os países que tinham a aviação como segurança nacional insistiu na manutenção do regime nacional de propriedade. Estas medidas protetivas aliadas ao forte crescimento da economia impulsionaram o setor americano que experimentou elevado crescimento no período pós-guerra.

No entanto, mudanças consideráveis ocorreram mudanças significativas na regulação econômica. Após desacreditar no potencial do modelo de regulação estrita devido às dificuldades relacionadas à redução da tarifa e de ganhos de primeiro país a impulsionar a competição no transporte aéreo foi os Estados Unidos da América em 1977.

As principais companhias criadas foram: LAP - Linhas Aéreas Paulistas (1943) e Lóide Aéreo Nacional (1947).

- Década de 1950

Os anos 50 foram marcados pela abertura do Brasil ao capital externo e pelo fim da era Vargas. Já com a guerra encerrada e com a maior facilidade de se realizarem transações comerciais com o resto do mundo, o setor brasileiro de aviação avançou, consolidando as empresas existentes no mercado. 
Um fato que também impulsionou o transporte aéreo de passageiros foi a construção de Brasília, iniciada pelo governo de Juscelino Kubitschek em 1956, fazendo assim com que a aviação tivesse papel de destaque no transporte de passageiros dos grandes centros, como Rio de Janeiro, então capital da república do Brasil, e São Paulo, para o centro do país.

As principais empresas criadas foram: Paraense (1952) e Sadia (1955), posteriormente chamada de Transbrasil.

- Década de 1960

A década de 1960 esteve envolta em um período de crise econômica, onde a inflação e a estagnação dominaram o cenário nacional. A crise perdurou até o ano de 1967, prejudicando severamente os mais diversos setores da economia, inclusive o de aviação civil. Nesta década houve o encerramento das atividades de uma grande empresa, a Panair em 1965.

Apesar da crise, a inauguração da nova capital federal, em 1960, foi responsável por boa parte da demanda por transporte aéreo no Brasil. O chamado período de intenso crescimento econômico batizado de milagre econômico (1967-1973) também contribuiu para o fortalecimento da aviação civil nacional.

A principal empresa criada foi: TAF - Taxi Aéreo Fortaleza (1961).

- Década de 1970

Segundo Smith e Cox (2008), o transporte aéreo norte americano era fortemente regulado pelo governo, este determinava todas as decisões relacionadas ao setor: entrada, fusões, prática de preços etc. Neste modelo, os preços eram muito elevados ao passo que o percentual de assentos ocupados era baixo. No início da década de 1970 a taxa de ocupação média era de cinquenta por cento. Após a desregulamentação que ocorreu no ano de 1977, o percentual de ocupação de assentos aumentou para setenta e cinco por cento. Estes números são justificados pelos ajustes para melhorar a eficiência e tornar o serviço mais acessível ao público em geral.

Segundo Morrison e Winston (1986), a desregulamentação nos Estados Unidos da América gerou um ganho de US\$ 6 bilhões (preços de 1977) no bem-estar dos viajantes bem como um aumento anual de US\$2,5 bilhões (preços de 1977) no lucro da indústria ao passo que algumas fusões que ocorridas no ano de 1980 reduziram os ganhos dos consumidores em \$ 423 milhões por ano devido à prática de tarifa mais alta em decorrência do maior poder de mercado.

Em outubro de 1978 foi promulgada a Lei de Desregulamentação Aérea nos EUA. Entre os principais benefícios ressalta-se: a redução de cerca de $40 \%$ da tarifa aérea, crescimento da demanda derivada das ações de marketing com a configuração hub-and-spoke.

No Brasil, os anos 70 figuraram como a década do "milagre econômico", onde a demanda por transporte aéreo cresceu e os investimentos aumentaram através, principalmente do endividamento das empresas, tornando-as, assim, empresas endividadas.

A política monetária expansionista e a facilitação do crédito, a abertura de novas empresas e os investimentos realizados foram uma espécie de catalisador da crise que se instauraria na década seguinte. 
As principais empresas criadas foram: Tavaj (1972), Votec (1976), Taba (1976), Rio Sul (1976) e Nordeste (1976).

\section{- Década de 1980}

Observando a experiência americana, as autoridades Europeias começaram a priorizar o incentivo à competição ao invés do monopólio no Reino Unido a partir do ano de 1987. Em 1991, a Autoridade de Aviação Civil (CAA) flexibilizou algumas regras, a principal foi a facilitação da entrada no mercado. Foram implementadas novas rotas na indústria, tal estratégia de implementação de novas rotas "hub-and-spoke" gerou uma concentração dos voos em regiões específicas. O principal objetivo era conseguir, assim como os EUA, adotar uma medida que gerasse mais eficiência de utilização das redes bem como a redução do valor das tarifas.

Para Scharpenseel (2001), o maior problema no transporte europeu era a falta de consolidação do mercado, este era dividido em três setores: viagem ao trabalho, viagem doméstica e viagem a serviço. Além disso, a viação era dividida por fatores geográficos, ou seja, havia diversos mercado distintos em todo o continente onde cada um aplicava a sua abordagem da política internacional de aviação para o seu respectivo mercado doméstico, este detinham total soberania sobre o seu espaço aéreo. Na Convenção de Chicago, alguns países chegaram a acordos bilaterais sobre o direito de sobrevoo e pouso em solo de outros Estados-membros. Tais acordos eram bastante rígidos inviabilizavam a realização de acordos multilaterais entre os países membros gerando um mercado altamente inflexível com acessos bastante restrito às linhas aéreas.

No Brasil, esta década foi marcada pela grande estagnação econômica, e foi denominada de "década perdida". Este período se deu pelo acerto das contas ocasionado pelos grandes investimentos e endividamentos do setor, realizados nos anos 70.

Dois outros fatores reforçaram o baixo crescimento da economia brasileira e a deterioração das contas públicas. O primeiro fato foi o segundo choque do petróleo no final dos 70 e segundo foi o aumento da taxa de juros nos Estados Unidos. Estes fatos que fizeram a crise perdurar por um longo período.

A política econômica recessiva que o Brasil foi obrigado a adotar por forças internacionais, fez com que a escassez de recursos para investimentos impedisse o crescimento do setor aéreo nacional, que já estava combalido pelo alto endividamento iniciado na década anterior.

Ao contextualizar as mudanças na regulamentação, Busto, Turolla e Oliveira (2006) afirmam que a visão da indústria de transporte aéreo como um bem público justificou-se devido à presença do governo como gestor, no decorrer do tempo, a gestão estatal se mostrou incapaz de assegurar a ampliação do acesso de maiores parcelas da população aos serviços de transporte aéreo. Nos anos 1970 houve uma grande expansão das operações no território nacional. Nos anos 1980 a trajetória construída com elevadas taxas de crescimento fora comprometida pela performance econômica do país, havendo nesse período o congelamento das tarifas abaixo do valor mínimo operacional que arrasou empresas do setor. Nesse período, empresas concessionárias eram obrigadas a continuar as suas operações mesmo no prejuízo, nos 1990 inicia a transição para o modelo mais competitivo no mercado doméstico brasileiro. 
Pode-se dizer que a década de 1980 foi o grande marco para a aviação brasileira, ocasionando a "quebra" de várias empresas e o fim do modelo de regulação estrita, iniciado nos anos 70 (Oliveira, 2007).

Mesmo com todos os fatos que impactaram negativamente o setor nos anos 80 , ainda houve a criação de empresas. Foram, então, criadas as empresas: Brasil Central (1986) e Presidente Transportes (1987).

- Década de 1990

Em 1993 foi aprovado o pacote de liberalização dos transportes aéreos europeus que substituiu os acordos bilaterais com um sistema multilateral no âmbito da União Europeia, com isso, todas as companhias aéreas dos Estados-membros passaram ser licenciadas sob condições semelhantes deixando o acesso irrestrito.

Os resultados positivos são parecidos aos ocorridos nos EUA, (redução de valor das passagens aéreas, aumento das linhas de operação e aumento da demanda decorrente das promoções de passagens aéreas).

A principal limitação da consolidação da abertura de mercado na União Europeia diz respeito à igualdade da competição, há a concessão de auxílios às companhias dos Estados- Membros que não são concedidos às outras companhias. Um dos auxílios é a alocação de faixas de horários nos aeroportos, nas companhias dos Estados-Membros têm prioridade, isso tornava a competição desigual. O resíduo desta prática é a ocorrência de congestionamento nos aeroportos.

Nos Estados Unidos, as consequências negativas neste período foram o elevado aumento da quantidade de companhias regionais (cerca de 100\%) e o aumento das fusões e aquisições com o intuito de obter um crescimento interno. Após a desregulamentação, houve cinquenta e uma fusões na aviação americana, em 1995 as seis maiores companhias aéreas detinham $82,7 \%$ do mercado. Várias companhias aéreas faliram neste período.

No Brasil, houve um início (tímido) da retomada do crescimento do setor de transporte aéreo no Brasil, em paralelo com várias medidas dos governos para estabilizar a economia.

Busto, Turolla e Oliveira (2006) definem que durante a década de 90 foram implementadas duas das três etapas de desregulamentação do setor de transporte aéreo brasileiro:

- A primeira etapa, iniciada em 1991, marcando o início da chamada Política de Flexibilização da Aviação Comercial, e que foi apresentada na $5^{\text {a }}$ Conferência Nacional de Aviação Comercial (CONAC) realizada naquele ano. As principais inovações foram a adoção do conceito de banda tarifária e a eliminação de barreiras à entrada de novas empresas no mercado interno. Essa política teve como resultado a implantação de um modelo mais competitivo em comparação ao vigente no período anterior, que era exercido sob maior controle da autoridade militar;

- A segunda fase foi marcada por um processo de intensificação da quase desregulamentação, ocorrido no final de 1997 e início de 1998. Naquele período foram expedidos dois importantes atos administrativos no sentido de acentuar a 
flexibilização e estimular a competição das operadoras: a Portaria 986/DGAC, de 18 de dezembro de 1997, que liberou as empresas para a prática de tarifas com descontos de até $65 \%$ sobre o valor de referência fixado, e a Portaria 05/GM5, de 9 de janeiro de 1998, que liberou "qualquer empresa aérea regular brasileira" para operar as chamadas "Linhas Aéreas Especiais", que são as linhas que ligam os aeroportos centrais (Ponte Aérea RJ-SP inclusa);

Durante o governo Collor foram privatizadas várias empresas estatais, extintos vários tipos de subsídios do governo, além da abertura da economia aos mercados mundiais.

Os fatos que mais chamam a atenção nesta década foram a constatação da situação financeira das três principais empresas aéreas brasileiras, Varig, Vasp e Transbrasil e o grande número de pequenas empresas criadas. O estado deplorável em que se encontravam as finanças dessas empresas fez com que a manutenção de suas atividades viesse a ficar insustentável.

As principais empresas criadas foram: Itapemirim Transporte Aéreo (1990), TNT/Sava (1991), Air Brasil (1991), TCB (1992), Jetsul (1993), Air Vias/Via Brasil (1994), Skyjet Brasil (1994), Helisul (1995), Penta (1995), Tropical (1995), Phoenix Brasil (1995), Interbrasil (1995), Rico (1996), Cruiser (1996), Transair Internacional (1997), Unex (1997), Avianca (1998), Amazônia (1999), BRA (1999).

- Década de 2000

Os anos 2000, contaram com a total liberalização do setor de aviação civil brasileiro, uma vez que houve a liberação das práticas tarifárias além do fato que ter ocorrido a retirada das barreiras de entrada. Desse modo, houve uma grande facilidade em entrar no setor. Com estas condições a empresa GOL entrou no mercado com uma proposta de preços menores e de baixo custo. Claro está que isto impactou diretamente a concorrência intrassetorial.

Segundo Busto, Turolla e Oliveira (2006), em 2001 ocorreu a terceira etapa do processo de desregulamentação. Ainda segundo os autores, essa fase também marca a redefinição tanto dos agentes no mercado (companhias aéreas e suas coalizões) como da própria autoridade reguladora (do DAC para a futura ANAC).

Segundo Guaranys (2010), houve uma retirada das barreiras de entrada do ponto de vista jurídico que potencializou a competição nos anos 2001-2002. Para Oliveira e Salgado (2006) todo o processo de flexibilização cumpriu o seu objetivo regulatório de liberalizar o mercado e promover um ambiente de incentivo a iniciativa privada e aos investimentos, ao passo que promoveu melhores condições de qualidade e preços adequados aos usuários.

No entanto, para Salgado (2008) essa estratégia de liberalização total foi interrompida fortemente motivada pela crise gerencial ocorrida na companhia Varig. O governo entendeu que os fatores que impulsionaram esse colapso foi o excesso de oferta e a nova dinâmica competitiva. Com isso, o governo federal estabeleceu diretrizes para o setor por meio das portarias do Departamento de Aviação Civil (DAC) 243/GC5, de 13 de março de 2003, dando início ao que vem sendo chamado de retomada da regulação no setor de transporte aéreo brasileiro.

Esta portaria estabeleceu que o DAC passasse a ter um papel moderador no objetivo de adequar a oferta do transporte aéreo e de impedir competições danosas e irracionais por meio de práticas predatórias. 
Salgado e Guimarães (2003) e Salgado e Oliveira (2006) afirmam que o DAC passou a responder a pedidos de importação de aeronaves, entrada de novas companhias e novas linhas aéreas de acordo coma sua avaliação subjetiva. Um dos instrumentos que passaram a dar subsídio às avaliações foram os estudos de viabilidade econômica prévia, processo semelhante ao período regulatório no que se refere ao controle da oferta.

Segundo Salgado (2008), em paralelo percorria o trâmite processual no Poder Legislativo projeto de lei visando à criação da Agência Nacional da Aviação Civil (ANAC), processo que se concluiu em 27 de setembro de 2005, com a promulgação da Lei. 11. 182. Seguindo os mesmos princípios das leis que criaram outras agências regulatórias, essa lei consagrou conceitos de mercado, como o regime de liberdade tarifária e livre mobilidade, prevendo ao mesmo tempo a atuação regulatória da agência para garantir a compatibilização entre a atuação das empresas e a adequada prestação de serviços aos usuários. 


\section{REFERENCIAL TEÓRICO}

\subsection{ORGANIZAÇÃO INDUSTRIAL}

Ghemawat (2007) afirma que a análise de cenários surgiu na idade média, as primeiras tentativas eram calcadas na análise oferta-demanda.

Cournot (1838) apresentou um estudo que apontou a ocorrência de equilíbrio de preços em condições de monopólio e duopólio (domínio do mercado por parte de duas empresas) nas quais ambas decidiam o nível de produção separadamente.

Contribuindo aos estudos relacionados ao tema, Chamberlim (1933) e Robinson (1933) nas quais adotaram a premissa de homogeneidade ao analisar situações de concorrência monopolística.

Com as limitações da análise oferta-demanda surge uma ideia nova sobre o tema. Mason (1939) afirma que a estrutura da indústria é um fator que influencia diretamente tanto a rentabilidade quanto a conduta dos compradores e dos vendedores.

Visando observar esse fenômeno na prática, Bain elaborou dois estudos focados na relação entre a estrutura e o desempenho. No primeiro estudo, Bain (1951) ao comparar a concentração e a lucratividade de duas indústrias concluiu que, as maiores empresas da indústria mais concentrada conseguiram praticar preços acima do mercado sem que sofrer com a diminuição das suas parcelas de mercado, fato que não pôde ser observado na indústria menos concentrada.

No segundo estudo, Bain (1956) concluiu que em alguns setores as empresas persistiam no aumento dos seus preços de venda em patamares acima do nível competitivo, no entanto, sem atrair novos participantes. Com isso, identificou três fatores básicos que constituíam verdadeiras barreiras à entrada de novos participantes, sendo elas: ocorrência de vantagem absoluta de custo para uma empresa já estabelecida (exploração de patente), nível relevante de diferenciação dos produtos e ocorrência de economias de escala.

O autor Joe Bain, foi precursor da área de pesquisa denominada OI (Organização Industrial) uma vez que vários estudos empíricos intersetoriais foram desenvolvidos, no entanto, seus estudos tiveram contribuição limitada na estratégia de negócios porque eram focados nas políticas públicas e utilizavam poucas variáveis para explicar o desempenho dos outros setores da economia.

Porter (1975) apresentou um documento que fazia uma crítica à análise estrutural de setores proposto por Bain (1951), tal documento apresentou uma proposta que consiste em deixar de enfocar a análise nos objetivos da política pública e direcionar a análise para a política de negócios com o foco na maximização dos lucros.

Para isso, Porter (1979) elaborou um arcabouço teórico voltado para a análise estrutural da indústria denominado "cinco forças competitivas". Este modelo tenta relacionar a rentabilidade média dos participantes de um determinado seguimento às cinco forças de mercado.

Porter (1979) defendeu que o retorno sobre o investimento numa indústria é tanto maior em relação ao custo do capital investido quanto mais fracas forem coletivamente as seguintes cinco forças básicas: (a) ameaça de novos participantes, (b) poder de barganha dos Página 19 
fornecedores, (c) poder de barganha dos compradores, (d) ameaça de substitutos e (e) competição entre os participantes. As cinco forças estão diagramadas na Figura 2.

Figura 2: Cinco forças de Porter

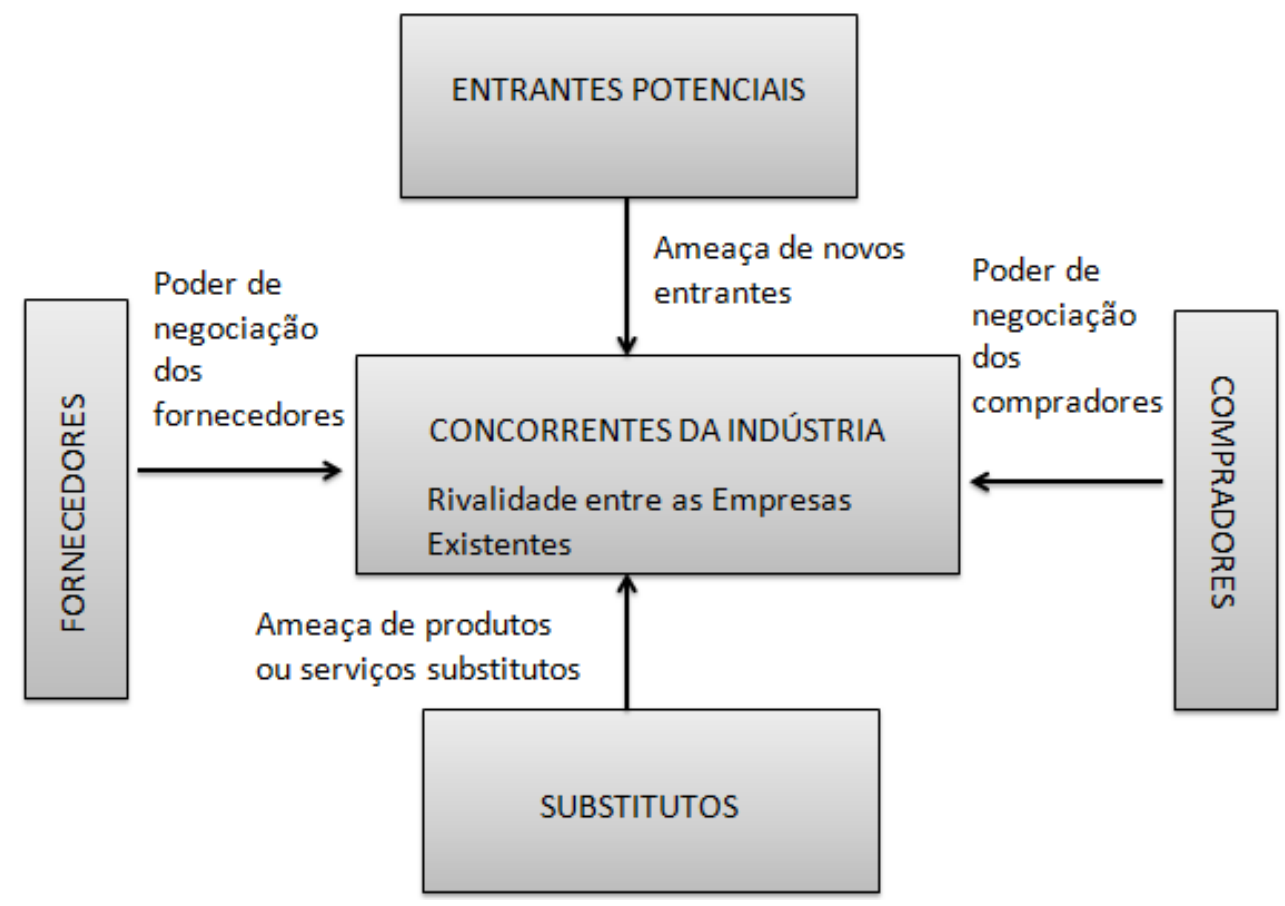

Fonte: Porter (1979).

Se uma indústria estiver entrincheirada ou for protegida da entrada de novos participantes, a força novos participantes é fraca. Se os fornecedores de uma indústria apresentam poder de negociação, a força fornecedores é forte. Se os compradores de uma indústria não têm poder de negociação, a força compradores é fraca. Se os produtos de uma indústria se deparam com bens alternativos mais atraentes em termos de preço, a força substitutos é forte. Se numa indústria houver baixa intensidade de rivalidade, a força concorrentes é fraca.

A seguir, discute-se detidamente as cinco forças do modelo de Porter e as suas principais características.

\section{Ameaça de entrada}

A entrada de uma nova empresa na indústria pode alterar a dinâmica competitiva bem como o nível de rentabilidade das empresas estabelecidas. A ameaça de entrada em uma indústria, depende das barreiras de entrada existentes, quanto maiores forem as barreiras menor a ameaça de entrada.

As principais barreiras de entrada são as economias de escala, necessidades de capital, acesso aos canais de distribuição e políticas governamentais.

A ocorrência de economias de escala força a empresa entrante a ingressar em larga escala arriscando sofrer forte reação das empresas existentes ou operar em pequena escala sujeitando-se a desvantagens de custo. Uma alternativa para as entrantes obterem vantagens 
nos custos é a realização de custos conjuntos, isso ocorre quando a empresa fabricando o produto A consegue produzir o produto B em paralelo.

Um grande fator que limita a entrada de novas empresas é a necessidade de capital que as empresas têm para ingressar em uma determinada indústria, principalmente quando o capital é requerido para atividades arriscadas e irrecuperáveis, um exemplo é a publicidade. Caso o capital esteja disponível nos mercados de capitais, a entrante faz um investimento com maiores riscos que refletirão nas margens cobradas, em situações como esta as empresas já estabelecidas detêm vantagem competitiva sobre as entrantes.

Toda empresa entrante precisa assegurar a distribuição de seus produtos para conquistar parcelas de mercado, no entanto, a entrante encontra dificuldades para ter acesso aos canais de distribuição uma vez que já estão sendo utilizados pelas empresas estabelecidas.

Uma empresa entrante pode conseguir acesso aos canais de distribuição por meio de persuasão exercida por descontos, verbas para campanhas publicitárias. Algumas barreiras são tão fortes que obrigam a entrante a criar um novo canal de distribuição porque os concorrentes existentes podem ter ligações com os canais calcados em relacionamentos duradouros no qual o canal se identifica com um determinado fabricante.

As políticas governamentais influenciam as indústrias como um todo, o governo pode assumir o papel tanto de comprador quanto de fornecedor. O governo pode afetar a posição de uma indústria com substitutos a partir de regulamentações, subsídios, ou outros meios. A rivalidade também pode ser afetada por meio de regulamentações ou até mesmo por desregulamentações. A análise da influencia do governo na indústria deve ser feita com base na atuação das políticas atuais e seus reflexos, pois, tanto a regulação efetiva quanto a ausência regulação são fatores que impactam nas indústrias.

\section{Fornecedores}

Os fornecedores podem exercer poder de negociação sobre os participantes de uma indústria podendo elevar os preços ou reduzir a qualidade dos bens e serviços fornecidos. Os fornecedores tornam-se poderosos quando a indústria de fornecimento é mais concentrada do que a indústria de consumo, isso ocorre porque a fragmentação de uma indústria é um fator de a torna mais frágil.

Quando uma determinada indústria não representa uma parcela significativa das vendas ou o produto dos fornecedores é importante para o negócio do consumidor, há o aumento do poder do fornecedor que tende a exercê-lo com mais intensidade.

\section{Compradores}

Os compradores competem com a indústria forçando os preços para baixo, barganhando por melhor qualidade ou maior nível de serviços, jogando os concorrentes uns contra os outrosesse efeito impacta negativamente na rentabilidade da indústria.

O poder de cada comprador da indústria depende de várias características do mercado, entre elas destaca-se: (a) a predominância de produtos padronizados e não diferenciados, (b) presença de poucos custos de mudança por parte do comprador, (c) aquisição de produtos na indústria que representem uma fração significativa de seus próprios custos ou compras e (d) acesso à informação total por parte do comprador. 
A predominância de produtos padronizados e não diferenciados dá ao comprador a escolha de optar por fornecedores alternativos, esse efeito leva as companhias aéreas a concorrerem para manter ou expandir as suas parcelas de mercado.

A presença de poucos custos de mudança por parte do comprador prendem os compradores a determinados vendedores diminuindo o seu poder de negociação, isso ocorre porque os compradores deixam de buscar novos clientes em decorrência da impossibilidade de encontrar custos menores.

A significância dos produtos adquiridos na indústria em termos de custos para o comprador é um fator que influencia o poder dos compradores, isso ocorre porque os compradores tendem a comprar de maneira seletiva a um preço favorável. Quando o preço dos produtos vendidos em determinada indústria significa uma fração pequena dos custos do comprador, em geral torna-se menos sensível ao preço.

O acesso à informação total por parte do comprador dá mais poder de negociação, principalmente quando as informações são estratégicas para as empresas, tais como: demanda preços reais e custos. Com isso, o comprador detém vantagem ao assegurar o recebimento de preços mais favoráveis que os oferecidos por outros fornecedores.

\section{Produtos substitutos}

A identificação de produtos substitutos é realizada pesquisando outros produtos que possam desempenhar a mesma função que outro em uma indústria. Os substitutos são aqueles que (a) estão sujeitos a tendências de melhoramento do seu trade-off de preço-desempenho em relação aos produtos da indústria ou (b) os que são produzidos por indústrias com altos lucros.

A ocorrência de produtos substitutos limita os lucros e reduz as fontes de riqueza de uma indústria, isso porque os substitutos reduzem potenciais e coloca um teto nos preços que as empresas podem fixar.

Quanto maior o nível de atratividade do preço-desempenho de um substituto, maior será a pressão sobre os lucros de uma determinada indústria.

\section{Concorrentes existentes}

A rivalidade em uma indústria ocorre quando as empresas se sentem pressionadas a melhorar a sua posição, para isso são usadas várias táticas como a concorrência de preços, batalhas de publicidade, introdução de produtos e aumento dos serviços ou das garantias ao cliente.

Contudo, a rivalidade é a consequência da interação de vários fatores estruturais de uma indústria, entre eles destaca-se: (a) concorrentes numerosos ou bem equilibrados, (b) concorrentes divergentes, (c) grandes interesses estratégicos e (d) barreiras de saída elevadas.

No entanto, a ocorrência de concorrentes numerosos ou bem equilibrados, algumas empresas podem acreditar que podem fazer movimentos sem ser notadas.

Quando uma indústria é altamente concentrada ou dominada por uma ou poucas empresas, há a ocorrência de uma ação coordenador da indústria, normalmente isso se dá por meios como liderança de custo. No entanto, é possível haver instabilidades na indústria mesmo sendo composta por poucas empresas caso sejam do mesmo tamanho, isso ocorre porque ambas podem estar dispostas a competir promovendo de fortes retaliações. 
Os concorrentes divergentes dão origem a objetivos e estratégias diferentes em uma mesma indústria. Em uma indústria menos concentrada, pode haver grandes dificuldades para entrar em acordos sobre a "regra do jogo".

Nesse contexto, algumas estratégias corretas para algumas empresas poderão ser estratégias erradas para outras. A concorrência pode se tornar tão latente que concorrentes altamente diversificados podem admitir retornos abaixo da média apenas para manter a independência de sua propriedade. Em mercados como este, a conduta adotada por pequenas empresas podem impactar na rentabilidade das maiores.

Os grandes interesses estratégicos estão diretamente relacionados aos objetivos de cada empresa em obter sucesso na indústria, uma das estratégias recorrentes em várias indústrias é o expansionismo. As empresas que adotam estratégias expansionistas normalmente visam práticas desestabilizadoras que geram necessários sacrifícios da própria rentabilidade para o prejuízo dos concorrentes.

As barreiras de saída elevadas são fatores capazes que manter as companhias competindo em atividades mesmo que estejam obtendo resultados financeiros negativos sobre seus investimentos. As principais barreiras de saída de uma indústria são: (a) ativos especializados, (b) custos fixos de saída, (c) inter-relações estratégicas, (d) barreiras emocionais e (e) restrições de ordem governamental e social.

Quando as barreiras de saída são altas, as empresas com prejuízos financeiros continuam operando até chegar a um nível que a única alternativa é recorrer a táticas extremas.

Após vários estudos setoriais aplicados com base em Porter (1979), Ghemawat (2001) faz uma contribuição à análise dos fatores estruturais. Para Ghemawat (2007), a análise das cinco forças competitivas deve ser realizada juntamente com a rede de valor proposta por Brandenburguer e Nalebuff (1996).

Figura 3: Rede de Valor.

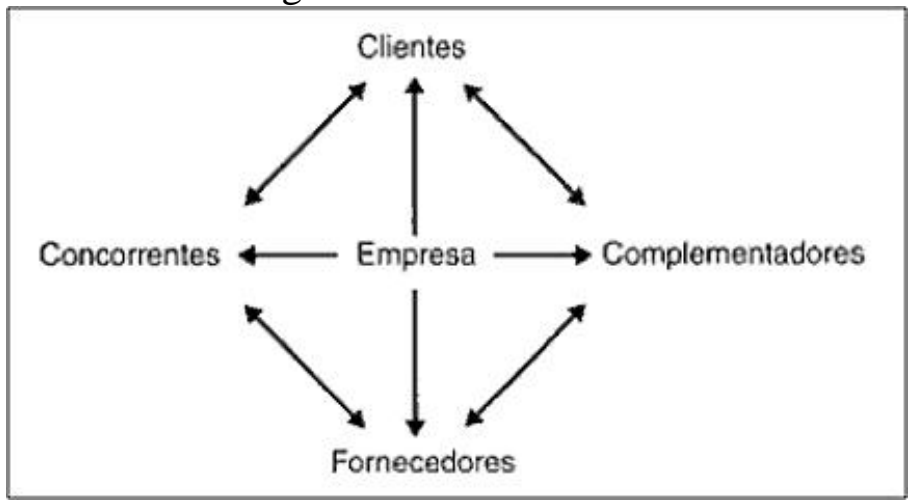

Fonte: Brandenburguer e Nalebuff (1996).

Brandenburguer e Nalebuff (1996) destacam a atuação de dos atores complementadores. Esta ocorre quando clientes compram produtos ou serviços complementares devido ao empenho do fornecedor em oferecê-los gerando um benefício para outra indústria.

Com isso, os complementadores adotam condutas de mercado inversas às adotadas pelos concorrentes. 
Ao analisar os cenários de negócios, Ghemawat (2001) percebeu que algumas variáveis precisavam ser incluídas na análise das cinco forças de Porter (1979), sendo algumas delas: associações de comércio, contato multimercado e instituições colaborativas. Ou seja, propõe a aplicação da análise das cinco forças competitivas com juntamente com a rede de valor conforme a Figura 4.

Figura 4: Proposta teórica de forças competitivas Ghemawat.

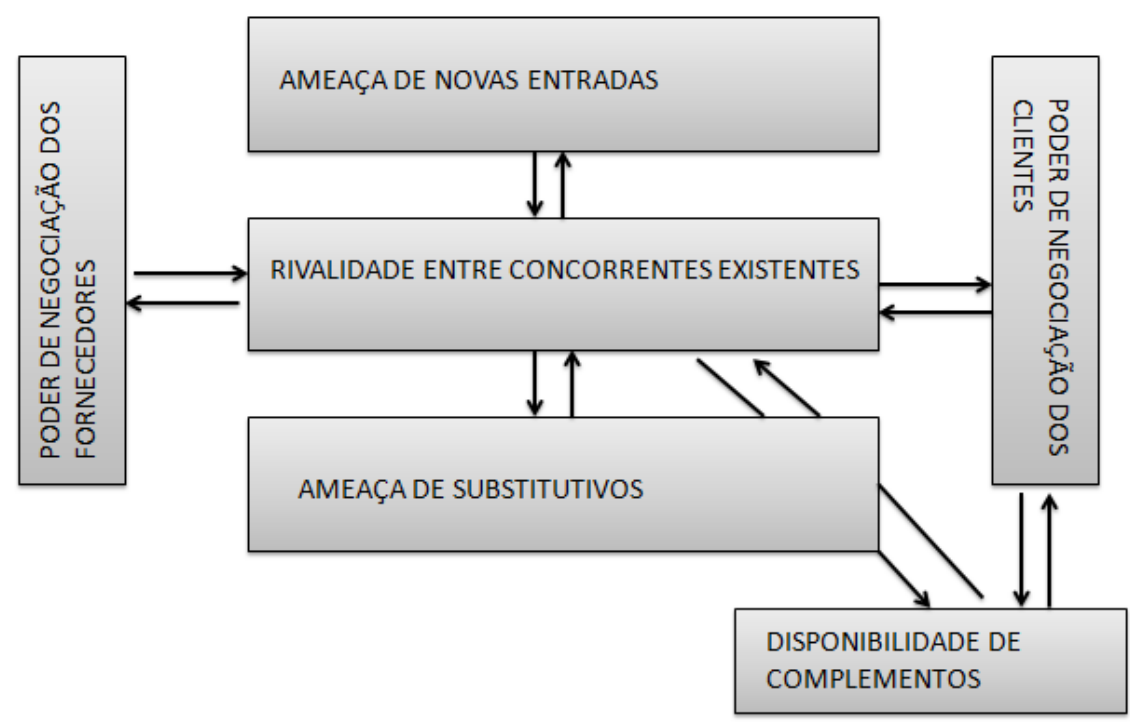

Fonte: Ghemawat (2001).

Com isso, Ghemawat (2007) propõe algo que pode ser considerado uma sexta forças, a ocorrência de agentes que desempenham atividades complementadoras influencia o desempenho da indústria tanto quanto as cinco forças competitivas de Porter.

Goldsmith (1991), afirma que ao longo as pesquisas em tecnologia da informação foram desconsiderando as abordagens tradicionais de Porter, a lógica das estratégias de negócios não vem sendo realizadas em paralelo às estratégias de avanço do planejamento estratégico da informação. Nesse contexto é possível perceber que as empresas que não desenvolvem uma boa estratégia de negócios consequentemente não têm uma boa estratégia de TI (Tecnologia da Informação). Visando propor uma metodologia mais apropriada para empresas GROUP (Operações Simon Limited), Goldsmith (1991) elaborou uma aplicação de questionários direcionados a altos executivos, as perguntas elaboradas foram baseadas nas cinco forças de competitivas juntamente com a rede de valor constituída e utilizaram-se as respostas para ponderar o nível de cada força na primeira etapa. Ao final, o autor conseguiu desenvolver um novo sistema de planejamento que incluiu o refinamento da maneira com que as empresas GROUP (Operações Simon Limited) realizavam o seu planejamento estratégico.

Slater e Olson (2002) ressaltam que ao longo do tempo alguns fatores presentes no ambiente de negócios como as táticas competitivas agressivas foram sendo percebidos, com isso buscam em seu trabalho apresentar um complemento ao modelo de cinco forças competitivas de modo que o resultado reflita as práticas competitivas que não abordadas por Porter, segundo eles trata-se de um modelo incompleto de análise. Os autores afirmam que a análise de mercado deve considerar a imprevisibilidade das mudanças, sendo que estes irão 
influenciar a rentabilidade média. Com isso, chegaram a uma reformulação do modelo de cinco forças competitivas sem excluir nenhuma delas conforma a Figura 5.

Figura 5: Proposta teórica de forças competitivas de Slater e Olson.

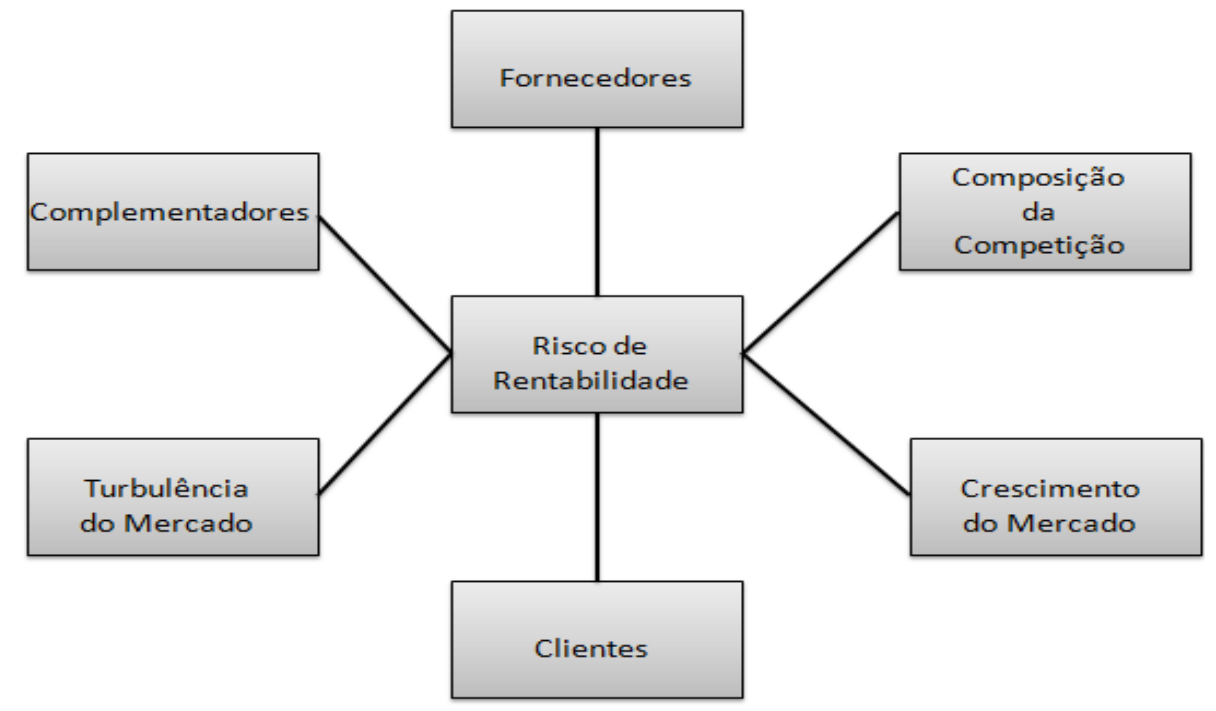

Fonte: SLATER e OLSON (2002).

O modelo é resultado de uma nova organização do modelo de Porter (1979), onde:

- A composição da competição é o resultado da junção entre: ameaça de produtos substitutos, ameaça de novos participantes e concorrentes.

- Complementadores é a presença de empresas parceiras.

- A turbulência de mercado são as possíveis mudanças capazes de impactar o cenário dos negócios.

- Risco de mercado está relacionado à variabilidade dos retornos de um mercado, de modo que se possam prever movimentos futuros e apresentar as tendências aos acionistas.

- Tanto a análise do poder de barganha dos fornecedores quanto dos compradores segue as mesmas premissas propostas por Porter (1979).

Song, Calantone e Benedetto (2002) usaram um desenho experimental para examinar o processo de tomada de decisões estratégicas em empresas localizadas nos Estados Unidos da América e do Japão. Para isso, desenvolveram várias proposições em relação à seleção gerencial de estratégias competitivas frente às forças competitivas (poder de barganha dos compradores, poder de barganha dos fornecedores, ameaça de produtos substitutos, ameaça de novos entrantes e concorrência entre as empresas). Os autores apresentaram dezesseis cenários, em cada cenário havia informações sobre proposições feitas a respeito das cinco forças competitivas. Consideraram que o poder de barganha dos fornecedores não é um fator interessante para comparar os EUA com o Japão. Com isso, mantiveram o poder dos fornecedores como constante, projetando um fatorial completo preservando a ortogonalidade dos critérios ( 1 X 2 X 2 X 2 X 2), desse modo gerando um total de 16 cenários. Foram elaboradas perguntas para saber qual estratégia competitiva os respondentes adotariam para se Página 25 
tornar mais competitivo em cada uma das proposições. $\mathrm{O}$ teste foi aplicado para uma amostra de 1.000 executivos seniores americanos e de companhias japonesas (500 de cada país), a mostra de questionários úteis para a pesquisa foi de 316 questionários de empresas norteamericanas e 459 de empresas japonesas.

Em seguida, buscou-se testar as proposições a respeito dos efeitos das forças competitivas sobre a seleção de uma das três estratégias genéricas (liderança no custo, diferenciação e enfoque) calculando as probabilidades de ocorrência.

O método de estimação foi o de máxima verossimilhança marginal (MML), as estatísticas mostraram uma capacidade explicativa muito boa, os valores de $\mathrm{R}^{2}$ variaram entre $0,589 \mathrm{e}$ 0,641, representando um razoável nível de ajuste.

Os resultados mostraram que os executivos dos dois países consideram os efeitos competitivos de forma diferente. Os gestores dos EUA são mais propensos do que os gerentes japoneses uma estratégia de liderança no custo ou estratégia de enfoque, se a ameaça de uma nova entrada é alta. Este achado pode ser um resultado indireto das ações de MITI (Ministry of International Trade and Industry). Este ministério protege os operadores históricos japoneses em muitas indústrias da ameaça de novos entrantes.

Douglas e Ryman (2003) analisaram a vantagem competitiva da indústria hospitalar nos Estados Unidos da América sob a ótica dos efeitos diretos e conjuntos da estrutura de mercado sobre o desempenho organizacional. A metodologia consistiu em uma análise de dados secundários referentes a 824 hospitais e aplicação de questionários a alguns especialistas da área, o questionário continha perguntas relacionadas à percepção dos mesmos em relação a influencia dos fatores estruturais no desempenho do setor. Os resultados mostraram que os gestores conseguiam realizar ações estratégicas, dessa maneira, mitigavam os efeitos negativos da estrutura de mercado.

Birkinshaw, Hood e Young (2004) buscaram entender a relação existente entre a performance das vinte e quatro subsidiárias multinacionais Escocesas estudadas com a denominada arena competitiva. Porter (1991), conceitua a arena competitiva como o ambiente onde ocorre à busca de uma posição competitiva favorável em uma indústria, ou seja, onde surge concorrência. A pesquisa tem caráter qualitativo, onde foram aplicados questionários nas representações da população de empresas subsidiárias na Escócia. O estudo concluiu que o ambiente concorrencial afeta o comportamento do empreendedor e o desempenho das empresas subsidiárias na Escócia.

Karagiannopoulos, Georgopoulos e Nikopoulos (2005) analisaram o impacto da internet sobre as regras de mercado e na forma como a empresa deve formular sua estratégia de negócios. Em paralelo à análise, foi realizada uma revisão do Modelo das Cinco Forças Competitivas visando propor algum ajuste. $\mathrm{O}$ estudo foi embasado em pesquisas bibliográficas, os resultados apontam para uma grande influência da internet para as estratégias das empresas. Desse modo, os autores concluem propondo a inclusão de uma sexta força competitiva, "Poder de Inovação".

Grundy (2006) propôs uma reorganização das cinco forças competitivas, esta propõe as denominadas microforças. As microforças são forças competitivas presentes na indústria que caracterizam cada uma das cinco forças competitivas propostas por Porter (1979). 
Figura 6: Modelo de micro forças competitivas

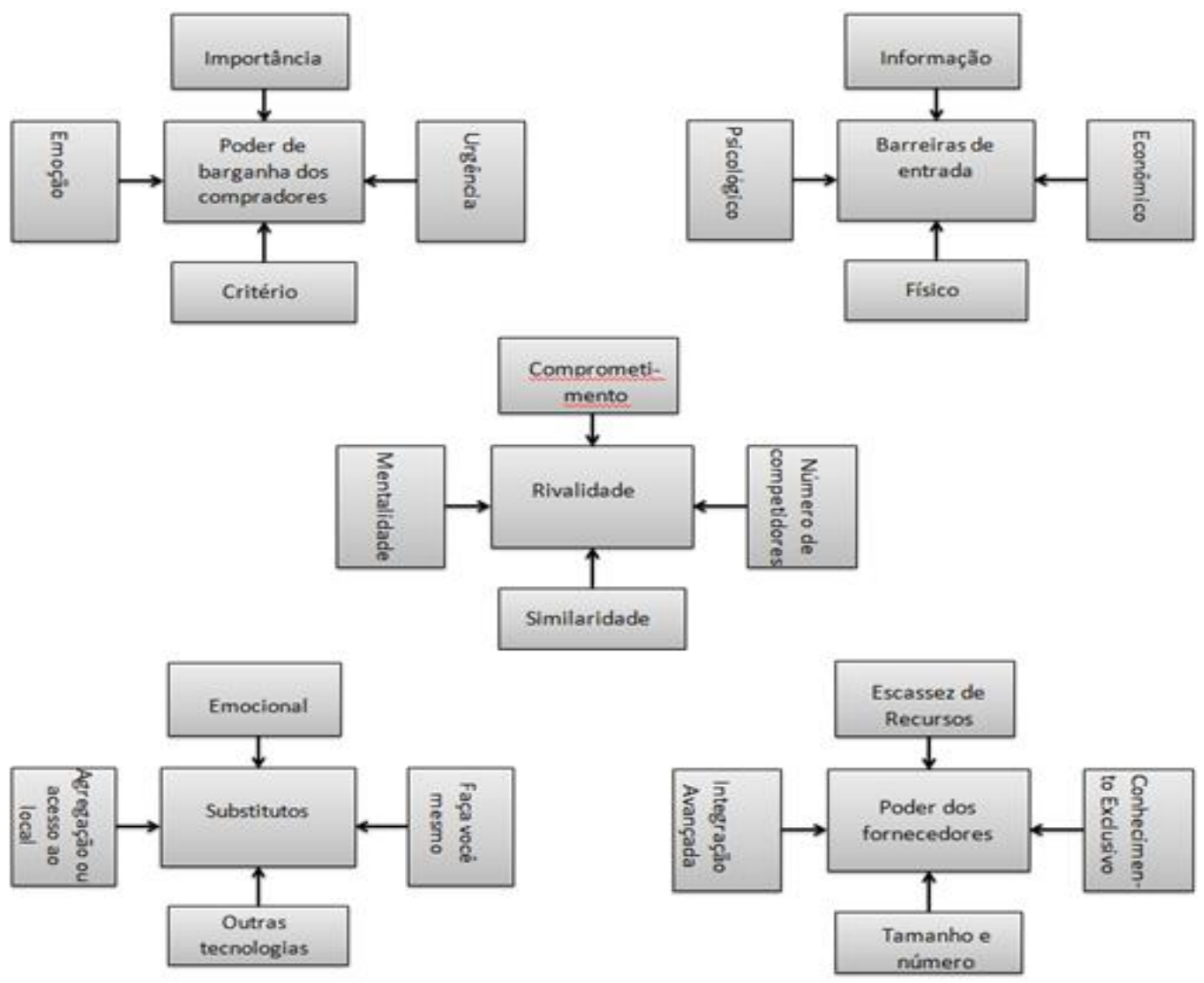

Fonte: Grundy (2006).

O poder de barganha dos compradores é influenciado por fatores motivacionais, tais como a importância do produto que caracteriza certo critério de escolha, fatores emocionais que capazes de induzir a vontade de adquirir o produto e a urgência. Dependendo do contexto estas microforças induzirão o indivíduo a adotar medidas que possam aumentar ou diminuir o seu poder de barganha.

As barreiras de entrada podem ser analisadas sob os seguintes aspectos:

- Físico: é possível obter acesso aos clientes ou recursos?

- Informações: até que ponto é possível adquirir conhecimentos sobre o mercado?

- Econômico: o que irá custar para entrar no mercado?

- Psicológico: esse mercado apresenta relevante nível de conforto para os que se propõem a explorá-lo?

A rivalidade é diretamente influenciada pelo número de jogadores e o nível de similaridade entre eles. Quanto mais comprometido forem maior será a rivalidade entre eles. Por fim, a mentalidade dos competidores irá influenciar a adoção de estratégias competitivas.

As microforças que norteiam os substitutos são diretamente relacionadas à conduta da própria empresa. A adoção de novas tecnologias ou a presença de patentes pode inviabilizar a 
presença de substitutos. Faça você mesmo refere-se ao intuito da empresa em desenvolver internamente as soluções que até o momento necessitavam de auxílio de outras instituições, esta microforça desencadeia a agregação de novos produtos ou serviços complementares ao negócio principal, esta pode fazer com que um produto seja considerado único perante os clientes. E a microforça "Emocional" refere-se aos motivos reais que influenciam as decisões.

O poder de barganha dos fornecedores do ponto de vista das microforças pode ser resumido por: conhecimento exclusivo, tamanho e número, escassez de recursos e integração avançada.

- Conhecimento único: se o fornecedor tem alguma capacidade única, esta aumenta o seu poder de barganha.

- Tamanho e número: onde há um número muito pequeno de grandes fornecedores, os fornecedores têm maior poder de barganha.

- Escassez de recursos: caso se trate de produtos escassos no mercado, os fornecedores terão maior poder de barganha.

- Integração avançada: caso haja integração para frente haverá uma melhora no seu poder competitivo.

Tavitiyaman, Qu e Zhang (2010) realizaram um estudo que tem por finalidade avaliar o desempenho do setor hoteleiro nos EUA baseado nas cinco forças competitivas de Porter utilizando aplicação de questionários elaborados em escala likert aos profissionais de alto escalão do setor. Os resultados mostraram que os hotéis com vantagem no custo apresentam baixo poder de barganha em relação aos clientes e baixa ameaça de novos entrantes. Os concorrentes que apresentam vantagem sobre os concorrentes não apresentam vantagem em relação à imagem da marca, recursos humanos e estratégias de TI. Em suma, os recursos humanos e de tecnologia da informação influenciam positivamente na rentabilidade dos hotéis de um modo geral, porém não impulsionam a vantagem competitiva entre eles.

O'Connor, Vera-Muñoz e Chan (2011) investigaram a relação entre as forças competitivas e a percepção das empresas chinesas listadas em bolsa a respeito da importância de implantar sistemas de controle de gestão. Para isso, foi feito um levantamento de dados: relatórios anuais das empresas chinesas na bolsa de valores, dados financeiros e anuários estatísticos da China. A segunda parte da pesquisa consiste em uma aplicação de questionários por telefone à executivos de empresas chinesas de fabricação e de empresas internacionais que operam na China.Os resultados mostraram que há uma associação positiva entre ameaça de concorrentes estrangeiros e a importância de que as empresas implantem sistemas de controle gerencial., esta associação é maior para as empresas que competem predominantemente no mercado doméstico do que para aqueles que competem predominantemente nos mercados internacionais. O impacto do poder de barganha dos compradores é maior para as empresas que competem no mercado internacional. As demais forças indicam também uma forte necessidade das empresas adotarem sistemas de controle gerencial para concorrer no mercado.

Hoque e Chia (2012) analisaram como a mudança no ambiente de negócios influencia na decisão de aquisição de sistemas de medição de desempenho. Este estudo utilizou uma abordagem qualitativa de estudo de caso, ao todo foram aplicados nove questionários a diretores de finanças, contadores, gerentes de produção e gerentes de marketing de diversos Página 28 
segmentos da indústria. As entrevistas variaram de uma a três horas cada uma, as respostas foram gravadas e posteriormente transcritas. Os resultados mostraram que as mudanças nas forças competitivas resultaram em alterações em nas estratégias das empresas para que estas pudessem obter vantagem competitiva resultando na aquisição de sistemas de medida de desempenho.

Ghazavi e Cherachali (2013) analisaram a influência da internet nas forças competitivas da indústria de seguros do Irã. A pesquisa tem caráter qualitativo, esta foi desenvolvida com base em questionários aplicados a alguns especialistas da indústria de seguros iraniana. Os resultados mostraram que internet influencia as cinco forças competitivas da indústria de seguros no Irã. Esta gera impactos significativos sobre como iniciar um negócio, na ameaça de substitutos, na satisfação do cliente, na imagem percebida bem como na qualidade percebida.

Zoharabi (2013) buscou aplicar uma metodologia que criasse um elo entre a gestão estratégica e a gestão de qualidade. A pesquisa dotou um método quantitativo de tomada de decisão multicritério denominado TOPSIS (Technique for Order Preference by Similarity to Ideal Solution) utilizado para classificação das estratégias. Segundo Amiri et al (2010), o TOPSIS (Technique for Order Preference by Similarity to Ideal Solution) é um método de análise multicritério que trabalha com o conceito de distâncias ao ponto ideal e anti-ideal conseguido superar técnicas anteriores. Este construiu uma tabela que ponderava aspectos relacionados às cinco forças competitivas aos sistemas de gestão estratégicos e de gestão da qualidade. $\mathrm{O}$ resultado atesta que este método é capaz de dar subsídio à formulação de estratégias qualitativas na organização diretamente relacionadas às áreas de gestão estratégica e gestão da qualidade.

No Brasil, há vários estudos voltados para análise de diversas indústrias baseados nas forças competitivas.

Antoni (1995) analisou a indústria ervateira do Rio Grande do Sul à luz das cinco forças competitivas de Porter. O método utilizado foi o estudo de caso, foram aplicadas entrevistas a executivos ligados à indústria que ocupavam cargos de direção ou gerência e especialistas do setor. Os resultados mostraram que no setor não existe fortes barreiras de entrada, as empresas rivais apresentam baixo poder de retaliação, não há produtos substitutos ao chimarrão por se tratar de um produto tradicional, o poder de negociação dos compradores é forte porque a maior parte da demanda advém de grandes redes de supermercados e o poder de barganha dos fornecedores é forte porque não há oferta abundante da matéria prima.

Binder (2003) se propôs a analisar a aplicabilidade dos modelos desenvolvidos por Porter (1979) em um estudo aplicado à companhia aérea GOL. Os resultados mostraram que a necessidade de revisão do conceito de cadeia de valor uma vez que a atividade de transporte aéreo não possui uma criação de valor e pode ser definida através de um sistema de atividades.

Domingos (2005) analisou o ambiente antes da desregulamentação do setor e concluiu que o grau de rivalidade era baixo uma vez que as empresas VARIG, VASP E TRANSBRASIL dominavam o mercado e mediante a baixa ameaça de novos participantes seguiam confortáveis havendo uma mudança no cenário com a entrada da TAM com sua política de encantamento dos passageiros. O setor sempre teve como substituto o transporte rodoviário de passageiros que por sinal ficou limitado em relação ao aumento das tarifas, no entanto, 
considera-se uma força forte porte as tarifas de transporte aéreo eram bastante elevadas. $\mathrm{O}$ poder de barganha dos compradores era baixo devido às bandas tarifárias e o poder de barganha dos compradores é elevado uma vez que as indústrias que fornecem os combustíveis e as aeronaves eram bastante concentradas.

Ao analisar a evolução do transporte aéreo no Brasil, Miotto (2008) conluio que as companhias GOL e TAM durante o período 2001-2005 obtiveram o melhor posicionamento estratégico na indústria, na qual adaptaram os seus produtos e serviços deixando de lado a ideia do voo ser um artigo de luxo e adequaram a sua frota e preços para a classe popular, desse modo conseguiu obter vantagem competitiva.

Melo (2009) aplicou a proposta teórica de Ghemawat (2001) para analisar o setor calçadista do Ceará. Esta consiste em analisar as cinco forças competitivas de Porter (1979) juntamente com a rede de valor proposta por Barry Nalebuff e Adam Brandenburger (1996). A pesquisa tem caráter exploratório, esta foi desenvolvida com base em pesquisa documental, realização de entrevistas e aplicação de questionários junto a profissionais do setor. Os resultados da análise da rede de valor identificaram a interdependência dos agentes de sua cadeia produtiva, chamados de jogadores e as relações de cooperação e competição que devem ser alteradas e preservadas a seu favor. Em relação às forças competitivas, conclui-se que o poder de negociação dos seus fornecedores é baixo, os compradores detêm nível médio de poder de negociação, a rivalidade na indústria é alta e a ameaça de produtos substitutos é alta.

Nogueira (2011) aplicou a análise das forças competitivas de Porter para analisar a influência da estrutura da indústria de telefonia da cidade de São Paulo no seu respectivo desempenho financeiro no período de 2007 a 2010. Este consistiu em um estudo exploratório baseado em dados secundários juntamente com a aplicação de questionários visando captar a opinião de especialistas do setor. O estudo concluiu que o setor de telefonia da cidade de São Paulo apresenta forças competitivas com baixa intensidade, este é o fator que melhor explica a rentabilidade positiva nos últimos três anos.

Gonçalves (2011) desenvolveu um processo de avaliação de aspecto internos, do ambiente externo e elaboração de cenários como base para a definição das estratégias de Planejamento Estratégico. A proposta elaborada pelo estudo é sustentada pela revisão da literatura. Os resultados finais propõem uma metodologia analítica composta por três fases:

- Aspectos Internos: Recursos Humanos, Produção, Financeiro, Marketing, Pesquisa e Desenvolvido e Comparação com os concorrentes e verificar se há vantagem competitiva;

- Ambiente Externo: Variáveis Políticas, Variáveis Econômicas, Variáveis Tecnologias, Variáveis Demográficas, Variáveis Sociais, Cinco Forças de Porter e Análise da atratividade do setor em relação às variáveis.

- Análise de Cenários: 1) Identificação dos objetivos estratégicos, 2) Análise das variáveis ambientais, 3) Seleção das principais variáveis, 4) Prospecção de cenários, 5) Relação das variáveis com os cenários, 6) Criação dos cenários, 7) Escolha dos cenários prováveis, 8) Definição das estratégias e 9) Monitoramento dos cenários e dos resultados através de indicadores. 
Giacchetta (2011) realizou um estudo sobre a Fazenda Ponto Alegre localizada no estado de Minas Gerais, esta atua no setor de produção de cafés especiais. Este estudo avaliou como a fazenda conseguiu obter vantagem competitiva no mercado de cafés especiais mediante as forças competitivas presentes na indústria. O estudo utilizou o método da entrevista semiestrurada, onde os entrevistados foram orientados por dois questionários. Um para avaliar como eram os métodos de trabalho e gestão da empresa e outro a respeito das cinco forças competitivas. Os resultados mostraram que tanto o mercado consumidor quanto o mercado fornecedor são muito concentrados, isso faz com que ambos tenham elevado poder de mercado, o mercado tem como possíveis produtos substitutos os refrigerantes, chás, achocolatados e sucos. Os novos entrantes têm acesso fácil aos canais de distribuição não existindo barreiras específicas que possam impedi-los, o grau de concentração é baixo e com uma tendência de continuar assim, isso devido o aumento das divisões das terras entre nas fazendas existentes. Com isso, a Fazenda Porto Alegre adotou a diferenciação como estratégia para se destacar dos seus concorrentes.

Ferreira, Santos e Reis (2011) analisaram a estrutura industrial da aviação civil em nível mundial com base em análise de dados secundários e concluiu que: de um modo geral a indústria não apresenta forte competição porque as maiores companhias do mundo buscam alianças estratégicas para evitar as perdas na competição, este tem como principal substituto o transporte marítimo em viagens intercontinentais e o rodoviário quando se trata de curtas distâncias. A entrada de novas empresas no setor é dificultada pelas elevadas barreiras de entrada como: elevado investimento inicial, a obtenção de licenças, os requisitos de mão de obra especializada e o espaço nos aeroportos, um fator relevante é que a entrada de uma nova companhia gera aumento na competição. No mundo, o poder de negociação dos fornecedores é relativamente alto uma vez que há poucos fornecedores de aeronaves, isso faz com que as companhias tenham poucas opções de troca de fornecedor e o combustível é uma commodity tendo, portanto, o seu preço de venda determinado pelas forças do mercado. O poder de negociação do comprador é relativamente baixo, uma vez que o preço é estipulado pelas companhias cabendo ao comprador comparar os valores entre as diferentes ofertas.

\subsection{MÉTODOS DE ANÁLISE}

\subsubsection{Razão de concentração - CR4}

Carvalho e Aguiar (2015) afirmam que o CR4 é um método utilizado para verificar o grau de concentração em uma indústria, este é parcialmente calculado a partir das parcelas de mercado das empresas líderes, demonstrando assim as respectivas participações no mercado sem especificar o número de empresas na indústria em análise.

Dessa maneira, é possível verificar o domínio de mercado das quatro maiores empresas juntas, o índice CR4 pode ser representado pela expressão:

$\mathrm{CRk}=\Sigma \mathrm{Si}$

Onde Si é a parcela de mercado da i-ésima firma, e k é igual a 4. Normalmente, os índices de concentração econômica são calculados com base na participação de cada firma no mercado.

Este índice foi amplamente utilizado em análise de indústrias, como em Feijo, Carvalho e Rodriguez (2003), Rocha (2010) e Costa e Garcias (2009). 
Neto, Araújo e Ponce (2008) analisaram a relação entre a estrutura de mercado e o grau de competitividade da indústria bancária brasileira. Os resultados indicaram um aumento da concentração entre os dez maiores grupos bancários e uma redução em todas as medidas de concentração para operações de crédito. No setor bancário, a maior concentração implica em menor grau de competição.

Machado et al (2010) avaliaram a concentração de mercado após a desregulamentação da indústria de laticínios. Após o cálculo de indicadores de desempenhos operacionais e financeiros calculados com base no modelo Fleuriet e a análise da estrutura de mercado por meio do indicador de estimação d razão - CR (k) do setor constatou-se que o aumento da concentração de mercado nesta indústria não se confirmou após a desregulamentação.

Aguiar e Fiqueiredo (2012) examinaram o impacto da concentração de mercado sobre o uso de poder de mercado para produtos agrícolas específicos. Os resultados apontaram que os varejistas tendem a retardar a transmissão de decréscimos de preços, transmitindo mais rapidamente os acréscimos.

Costa e Santana (2014) utilizaram este índice para mensuraram a concentração de mercado ao longo da cadeia produtiva da soja. Os resultados indicaram que o produtor rural de soja se encontra em uma situação de fragilidade econômica por dois motivos: a) adquire insumos em mercado oligopolizado e vende a produção em mercado oligopsonizado e, b) as empresas dominantes estão protegidas por barreiras à entrada.

\subsection{2 Índice de Hirschman- Herfindahl (HHI)}

De acordo com Martin (1993) pesquisadores preocupados com o exercício privado de poder de mercado desenvolveram o que veio a ser conhecida como a abordagem estrutura-condutadesempenho dentro da análise industrial. Considerando a visão mais básica dessa abordagem, a estrutura de mercado determina o comportamento das empresas, e o comportamento dessas empresas determina os fatores que caracterizam o desempenho de mercado. Conhecer, a estrutura dos mercados industriais é crucial para o entendimento de toda sua dinâmica.

Geralmente, o poder de influenciar o mercado é exercido em mercados oligopolistas, segundo Labini (1980), são mercados formados por um pequeno número de empresas que concorrem entre si através de aumentos de participação no mercado onde há presença de economias de escala. Uma das principais barreiras de entrada nesse mercado é o elevado aporte de capital para montar a estrutura e investir em aparatos tecnológicos.

Segundo Barrionuevo e Lucionda (2004) há no setor de aviação civil situações de monopólio e oligopólio, devido o número de concorrentes, os agentes podem influenciar ou até mesmo definir o preço de mercado.

Silva Leite (1998) indica que a concentração de mercado pode ser analisada através de duas óticas: uma estática, em que as concentrações industriais são analisadas em um ponto fixo no tempo, e uma dinâmica, onde a análise é feita a partir de comparações intertemporais, nas quais são possíveis as avaliações da variação da concentração industrial.

Kupfer e Hasenclever (2002) afirma que o nível de concorrência pode ser verificado pelo índice de concentração industrial, quanto maior for o índice menor será a concorrência. 
Kupfer e Hasenclever (2002) definem a estrutura de pesos implícita no índice HH como $\Sigma \mathrm{si}^{2}$. Ao elevar cada parcela de mercado ao quadrado atribui-se maior peso às empresas maiores, quanto maior o $\mathrm{HH}$ menor será a competição entre as firmas.

O índice HH varia entre 1/n e 1 . O limite superior do índice está associado ao monopólio, ou seja, apenas uma empresa opera no mercado. No limite inferior, o índice assume o valor mínimo $\mathrm{HH}=1 / n$, isto é, quando todas as empresas têm o mesmo tamanho (si $=1 / n)$. Temse $1 / n \leq \mathrm{HH} \leq 1$.

O limite inferior de $\mathrm{HH}$ decresce na medida que o número de empresas aumenta, no entanto, há situações que isso não ocorre. Pode ser que a entrada de uma empresa na indústria seja compatível tanto com o crescimento quanto com a redução na concentração medida por $\mathrm{HH}$, isto pode ser visualizado em termos do coeficiente de variação das parcelas de mercado. Onde a média destas é $1 / n$, a variância é $\mathrm{V}(\mathrm{s})=1 / n \mathrm{HH}-(1 / n)^{2}$.

O coeficiente de variação empírico $\mathrm{CV}$ é a razão entre seu desvio padrão e a sua média, $\left(\mathrm{CV}_{\mathrm{s}}\right)^{2}=\mathrm{V}(\mathrm{s}) /(1 / n)^{2}=n \mathrm{HH}-1$, ou ainda,

$\mathrm{HH}=1 / \mathrm{n}\left[\mathrm{CV}_{\mathrm{s}}^{2}+1\right]$

Para George \& Joll (1983), as características estruturais de uma indústria influenciam no comportamento das firmas, bem como preços, lucros e atividades inovadoras resultantes do mercado. Essas características podem proporcionar maior poder de mercado para uma ou mais empresas em um mercado. Segundo Martin (1993), o poder de mercado refere-se à habilidade das empresas em influenciar os preços dos produtos que vendem, podendo optar por reduzir o bem-estar econômico ao sustentar preços de venda mais baixos mantendo a mesma parcela de mercado.

As dificuldades financeiras são características do setor de transporte aéreo de passageiros, Oliveira, Scarpel e Oliveira (2008) ressaltam que são frequentes nas companhias aéreas "situações de crise e fragilidade financeira", que, em última instância, acarreta na sua saída do mercado, gerando problemas para credores, funcionários e também a consumidores que sofrerão uma descontinuidade do serviço através de uma restrição da oferta.

O desempenho das companhias aéreas é influenciado por múltiplos fatores endógenos e exógenos à firma, Domingos (2005) aponta os principais fatores que impulsionaram as companhias VASP e VARIG ao colapso financeiro. Segundo o autor, a saúde financeira das companhias VASP e VARIG foi fortemente afetada pela concorrência direta das companhias GOL e TAM respectivamente, os reflexos foram percebidos internamente por meio do encolhimento da redução do patrimônio líquido, redução da quantidade voos, redução da frota e aumento do endividamento.

É possível notar que a estrutura do mercado é um fator crucial em qualquer mercado, Hollanda (1983) utiliza o modelo estrutura-conduta-desempenho para relacionar variáveis que meçam aspectos da estrutura de mercado (concentração, diferenciação, barreiras à entrada, etc.) com o comportamento das empresas (política de preços, pesquisas e inovações, propaganda, etc.), e este com variáveis de desempenho (tais variáveis procuram refletir a eficiência na adoção de novas técnicas, progresso econômico, etc.). 
Conforme Resende e Boff (2002) as medidas de concentração têm o intuito de analisar o meio em que os agentes econômicos utilizam para apresentar um comportamento dominante em um mercado específico, o que condicionam os diferentes indicadores, como a parcela de mercado da empresa em determinado mercado. Uma medida importante é o índice de concentração, este fornece uma síntese da concorrência existente em determinado mercado.

Silva Leite (1998) afirma que a avaliação intertemporal do índice de concentração possibilita verificar o número de firmas envolvidas na indústria e a evolução da desigualdade de tamanho entre essas empresas. Tais fatores são determinantes para o estabelecimento de preços e quantidades, assim como os incentivos e capacidade de inovação e barreiras à entrada de novas empresas.

Salgado, Vassalo e Oliveira (2009) defendem que a política de preços tarifários do setor de aviação civil impacta na economia brasileira, entre os anos 1998-2002 houve uma guerra de preços entre as operadoras de transporte aéreo de passageiros gerando uma contribuição indireta para a queda da inflação.

A experiência americana mostra que o setor de transporte aéreo americano passou por um processo de desregulamentação que deixou o mercado mais competitivo, as companhias aéreas buscaram aumentar a sua quota de mercado e passaram a oferecer tarifas menores.

Windle e Dresner (1995) ao analisar os efeitos da entrada de uma companhia aérea de baixa tarifa no mercado por meio de uma simulação, concluíram que a concentração não foi um fator contribuinte significativo para o estabelecimento dos preços da tarifa de transporte aéreo de passageiros nos mercados nacionais. Uma questão importante apontada pelos autores é que as suas participações foram significativas e a concentração não foi estatisticamente significativa.

Bauer e Zlatoper (1989) realizaram uma análise dos fatores determinantes no estabelecimento do valor tarifário em Cleveland, a conclusão foi de que a ocorrência de aumento no número de transportadoras gerava diminuição do valor médio da tarifa de transporte.

Evans e Kessides (1993) realizaram pesquisas com o intuito de estudar empiricamente o comportamento dos preços das companhias aéreas, os resultados mostraram que existem duas categorias de estudos capazes de fazer uma boa leitura dos elementos fundamentais. A primeira denominada "inter-rota" analisa as passagens aéreas em comparação a dados desagregados ao nível de rota, tais como: distância de voo, número de companhias presentes, etc. A segunda denominada "intra-rota" é difundida pelos trabalhos realizados por Borenstein (1989), Evans e Kessides (1993) e Oliveira e Huse (2005), esta realiza a análise introduzindo características específicas das companhias, tais como: quantidades de assentos, quilômetros percorridos por passageiros pagantes, etc.

\subsubsection{Elasticidade preço da demanda}

Segundo Silva e Lima (2004), a teoria do consumidor postula que os indivíduos são racionais e se comportam para atingir o maior nível possível de satisfação. Logo, se as preferências são ordenadas, elas podem ser representadas pela função de utilidade direta (FUD), da seguinte forma:

$\mathrm{U}=\mathrm{U}(\mathrm{X}, \mathrm{Q}, \mathrm{T})$ 
em que, $\mathrm{X}$ é um vetor de quantidade dos bens de mercado; Q, vetor de bens públicos (recursos e serviços ambientais), em que as quantidades são fixadas pelo indivíduo; e T, vetor de tempo utilizado em várias atividades que produzem a utilidade do indivíduo.

Considerando-se que as escolhas dos indivíduos objetivam maximizar sua utilidade, dados os preços e dada a existência de uma restrição orçamentária, sendo a renda fixa, o problema de maximização de utilidade do consumidor pode ser expresso da seguinte forma:

$\operatorname{Max} \mathrm{U}=\mathrm{U}(\mathrm{X})$

s.a $=\sum_{i=1}^{n} P i * X=M$,

em que, $\mathrm{X}$ é um vetor de quantidades $(\mathrm{X}=\mathrm{X} 1, \mathrm{X} 2, \mathrm{X} 3 \ldots, \mathrm{Xn}) ; \mathrm{P}$, vetor de preços $(\mathrm{P}=\mathrm{P} 1, \mathrm{P} 2$, P3, ..., Pn); e M, renda.

A solução desse problema fornece a função de demanda ordinária (função de demanda marshalliana), dada por:

$\mathrm{Xi}=\mathrm{Xi}(\mathrm{P}, \mathrm{M})$.

A equação (6) relaciona a quantidade ótima de determinado bem com os preços e com a renda monetária constante. Ao determinar as quantidades ótimas de cada bem $\mathrm{Xi}$, o consumidor estará atingindo o maior nível possível de utilidade. A partir da determinação das demandas marshallianas é possível quantificar o excedente do consumidor.

Segundo Tavares e Gimenes (2012), o consumidor apresenta vários comportamentos e objetivos, sendo os principais:

- O consumidor dispõe de determinada renda;

- O objetivo do consumidor é maximizar a diferença entre benefícios e custos, ao escolher o conjunto de produtos que a sua renda lhe permite comprar;

- De posse de sua renda, o consumidor vai ao mercado para comprar determinada quantidade de um conjunto de bens, formando uma cesta de consumo;

- Esta cesta de consumo depende das preferências (gosto), da utilidade dos bens (grau de satisfação) e da renda do consumidor;

- Ele conhece1 as informações sobre os bens e serviços disponíveis no mercado (os preços, a oferta de bens alternativos e o grau de satisfação que cada bem proporciona);

- Os gastos do consumidor estão limitados à sua renda (restrição orçamentária). A restrição orçamentária significa que o consumidor pode gastar um total igual ou menor que sua renda - o salário.

A Teoria da Demanda é derivada da hipótese sobre a escolha do consumidor entre diversos bens que seu orçamento permite adquirir. Essa procura individual seria determinada pelo preço do bem ou serviço, o preço dos outros bens, a renda do consumidor e o gosto ou preferência do consumidor.

Segundo Vasconcellos (2004), há uma relação inversamente proporcional entre a quantidade procurada e o preço do bem, ceteris paribus. É a chamada lei geral da demanda. Essa relação 
quantidade procurada/preço do bem pode ser representada por uma escala de procura, curva de procura ou "função demanda".

Figura 7: curva de quantidade procurada/preço do bem.

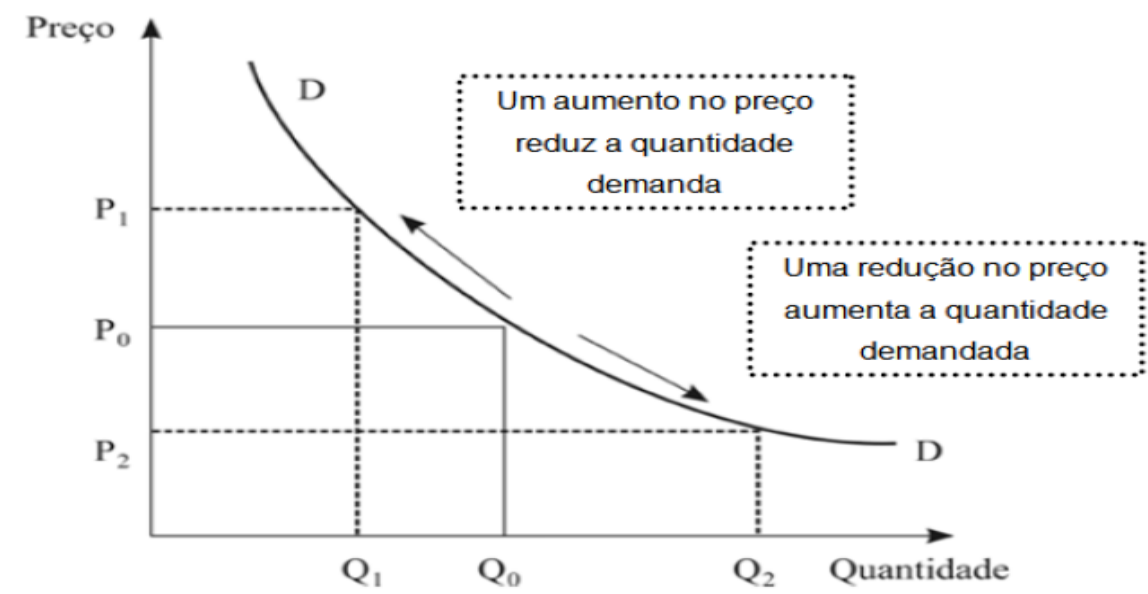

Fonte: Denise (2007).

De maneira resumida, pode-se afirmar que a procura por um determinado bem ou serviço aumenta ou diminui de maneira inversamente proporcional ao preço praticado quando todas as demais variáveis se mantêm constantes (ceteris paribus). Estabelecida esta condição, a procura aumenta quando o preço de venda diminuir e vice versa.

Mello (2010) descreve os fatores capazes de provocar um deslocamento da curva de demanda para cima ou para baixo, conforme Quadro 1.

Quadro 1: fatores que influenciam os deslocamentos da curva de demanda.

\begin{tabular}{|c|c|}
\hline $\begin{array}{r}\text { Fatores que causam aumento da } \\
\text { demanda e deslocamento da curva para } \\
\text { cima (direita) }\end{array}$ & $\begin{array}{r}\text { Fatores que causam queda na } \\
\text { demanda e deslocamento da curva para } \\
\text { baixo (esquerda) }\end{array}$ \\
\hline $\begin{array}{r}\text { - aumento na renda do consumidor } \\
\text { aumento no preço dos bens } \\
\text { substitutos } \\
\text { - queda no preço dos bens } \\
\text { complementares } \\
\text { - melhora nos hábitos do consumidor }\end{array}$ & $\begin{array}{r}\text { - queda na renda do consumidor } \\
\text { - queda no preço dos bens substitutos } \\
\text { - aumento no preço dos bens } \\
\text { complementares } \\
\text { - deterioração nos hábitos do } \\
\text { consumidor }\end{array}$ \\
\hline
\end{tabular}

Fonte: Mello (2010).

Denise (2007) ilustra os fatores capazes provocar um deslocamento da curva de demanda para cima na Figura 8. 
Figura 8: Deslocamento da curva de demanda

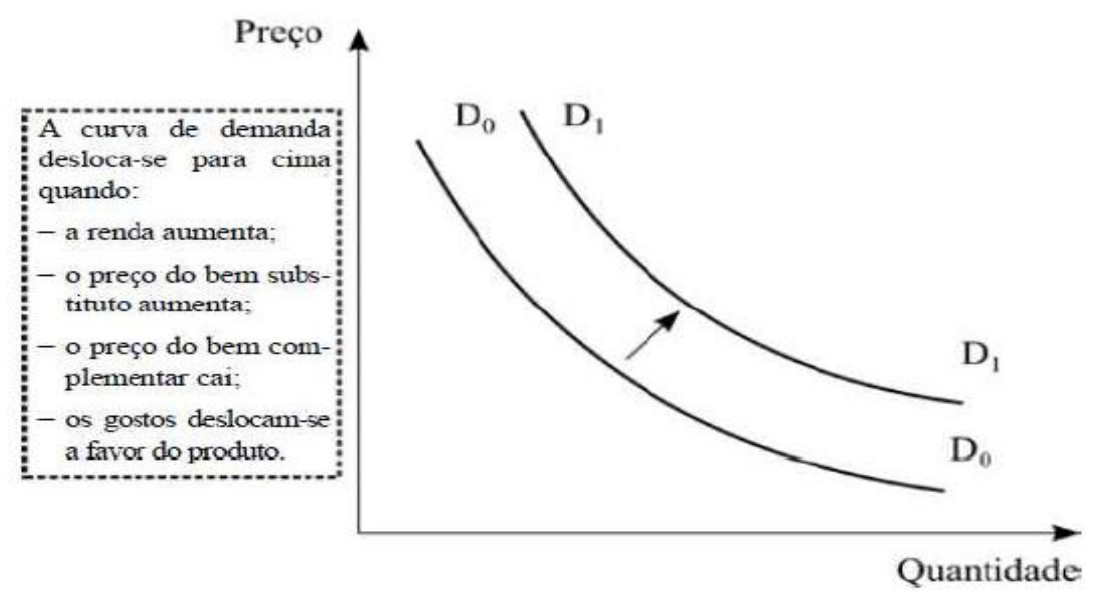

Fonte: Denise (2007).

Tavares e Gimenes (2012) descrevem as variáveis capazes de influenciar a escolha do consumidor, na maioria dos mercados de bens e serviços:

- $\mathrm{Pi}=$ Preço do bem

- $\quad$ ps = preço dos bens substitutos ou concorrentes

- $\mathrm{pc}=$ preço dos bens complementares

- $r$ = renda do consumidor

- $\mathrm{g}=$ gostos, hábitos e preferências do consumidor

Nem todos os bens são iguais, quando a renda do consumidor cai e a demanda aumenta significa que o bem questão é inferior. Bens substitutos são aqueles que têm um aumento da procura em decorrência do aumento do preço de outro bem que o substitui. Os gostos também influenciam, quando o consumidor gosta de um produto tende a comprar mais.

Quando o preço do bem ou serviço aumenta, os ofertantes tendem a aumentar o nível de oferta, quando o preço cai diminuem a oferta. Esta relação é inversa em relação aos preços dos insumos, quando os preços dos insumos aumentam a oferta tende a ser menor em decorrência do maior custo unitário de produção e vice versa.

Quando há excesso de oferta, o ofertando tende a oferecer um preço menor com o intuito de atrair uma maior demanda com o propósito de negociar o seu excedente. O contrário também ocorre, quando há excesso de demanda os consumidores ficam mais dispostos a pagar um preço mais elevado uma vez que o produto está relativamente escasso.

É comum ver o ofertante expandindo o seu nível de produção em decorrência do aumento de preços gerado pela demanda excessiva e em seguida haver uma redução no preço em decorrência desta expansão.

A elasticidade preço da demanda aponta o quanto que uma variação percentual no preço de um determinado bem ou serviço influencia a demanda do mesmo bem ou serviço. Esta é expressa pela equação (7): 
nj = variação percentual na quantidade demandada de $\mathrm{j} /$ variação percentual no preço de $\mathrm{j}$, ou símbolos,

$\mathrm{nj}=\Delta \% \mathrm{q} / \Delta \% \mathrm{pj}$

onde:

$\Delta \% \mathrm{qj}=\Delta \mathrm{qj} / \mathrm{qi}=($ quantidade demandada final - quantidade inicial $) /$ quantidade inicial

e a variação percentual no preço é dado por :

$\Delta \% \mathrm{pj}=\Delta \mathrm{p} / \mathrm{pj}=($ preço final - preço inicial $) /$ preço inicial, a expressão $(\mathrm{x})$ pode ser reescrita como:

$\mathrm{Nj}=(\Delta \mathrm{qj} / \mathrm{qi}) /(\Delta \mathrm{pj} / \mathrm{pj})$

Uma demanda é elástica quando o resultado é maior do que 1, inelástica quando é menor do 1 e elástica unitária quando é igual a 1.

O aumento na renda dos indivíduos aumenta a demanda por bens normais e diminui a procura por bens inferiores, o efeito renda da demanda é dado por:

$\mathrm{ERd}=\Delta \% \mathrm{Qd} / \Delta \% \mathrm{R}$

Onde:

$\Delta \% \mathrm{Qd}=\Delta \mathrm{Qd} / \mathrm{Qdi}=($ demanda no período final - demanda no período inicial $) /$ demanda no período inicial

E variação de R é:

$\Delta \% \mathrm{R}=\Delta \mathrm{Rj} / \mathrm{Ri}=($ demanda no período final - demanda no período inicial $) /$ demanda no período inicial

Levi (2009) estudou a logística de produção na indústria sucroenergética no Brasil, seguida pela estimação da demanda de cana-de-açúcar, açúcar e etanol. Os resultados indicaram que entre os produtos derivados da cana-de-açúcar, o açúcar não é um bem inferior uma vez que a sua demanda não diminui com o aumento da renda do brasileiro, esta apresenta valor de elasticidade-renda da demanda maior do que uma unidade. Já na demanda de álcool, observase que esta não reage aos preços.

Martins e Martinelli (2010) utilizaram a elasticidade preço da demanda para desenvolver uma ferramenta para prever o comportamento dos ciclos de crescimento e retração de uma commodity especificamente o açúcar. Com a proposta, o estudo conclui que é possível montar um instrumento informativo para sinalizar o comportamento futuro do preço do açúcar com base em indicadores antecedentes desta commodity. 
Santos el al (2011) estimaram as elasticidades preço e renda das exportações e importações, para os estados do Brasil, no período de 1992 - 2007. Os resultados mostraram que há relação elástica entre PIB e importações e inelástica negativa entre taxa de câmbio real e importações.

Ultremare (2012) avaliou os impactos do avanço do agronegócio brasileiro e da evolução de seus preços relativos no consumo de camadas diferentes da população rural e urbana no período 1995 a 2010. Os resultados apontaram que as variações de preço de produtos do agronegócio tende a afetar e sentido contrário o consumo da população rural especialmente a faixa de baixa renda (que obtém parte importante de sua renda no agronegócio) e no mesmo sentido o consumo da população urbana.

Bezerra, Silva e Lima (2013) investigaram a operacionalidade do canal de crédito bancário no Brasil e no Nordeste. Os resultados obtidos para a economia brasileira revelam que a oferta de empréstimos exerce importantes efeitos sobre as flutuações do produto e do voluma real de crédito, a principal de choques na oferta de crédito é a política monetária, expondo indícios da existência do canal de crédito bancário.

Mendonça e Sachsida (2013) estimaram um sistema de oferta e demanda de crédito bancário no Brasil a partir de dados agregados entre junho de 2000 e agosto de 2012, para os seguimentos de crédito de pessoa física (PF) e pessoa jurídica (PJ). Entre as conclusões encontradas, ressalta-se que a elasticidade-preço da demanda por crédito para PJ é maior do que a obtida para PF, corroborando o fato de que as empresas possuem outras fontes de financiamento.

\subsubsection{Simulação Monte Carlo}

Toda vez que a incerteza associada à verificação de determinado evento possa ser quantificada por meio de uma distribuição de probabilidade dos diversos resultados previstos, diz-se que a decisão está sendo tomada sob uma situação de risco. Desta maneira, o risco pode ser entendido pela capacidade de se mensurar o estado de incerteza de uma decisão mediante o conhecimento das probabilidades associadas à ocorrência de determinados resultados ou valores. (ASSAF, 2003).

O campo de pesquisa que lida com o risco evoluiu bastante, atualmente as pesquisas estão a considerando a influência do ambiente externo na quantificação. A construção de cenários é uma técnica importante para a estimativa de risco uma vez que incorpora as perspectivas reais à análise.

Tratando de operações no mercado financeiro, há quatro grandes grupos de risco: risco de mercado, risco de liquidez, risco de crédito e risco legal.

Segundo Goulart (2003), o risco de mercado pode ser entendido como a chance de haver perdas em função de oscilações de indicadores econômicos, como taxa de juros e de câmbio e preços de ações.

Há várias modalidades de classificação de riscos, tais como: risco de taxa de juros, risco cambial, risco de preço de ações e risco de commodities. Segundo Francis (1991), ocorrem perdas decorrentes de oscilações na questão em cada uma das modalidades.

Segundo BCBS (1988), o risco de juros é a exposição financeira do banco a movimentos adversos na taxa de juros, de maneira análoga o risco de taxa de juros e risco de câmbio é a 
probabilidade de perdas em virtude de variações adversas na taxa de câmbio, Capelleto e Corrar (2008). Ainda segundo Capelleto e Corrar (2008), a taxa de juros é administrada internamente e consiste em uma decisão até certo ponto autônoma da autoridade monetária e taxa de câmbio é determinada por fatores externos não controláveis pelos países.

Para Duarte (1996) é possível mensurar o risco de mercado de forma relativa, caso em que se mede o grau de deslocamento em relação a um determinado índice de referência (benchmark), ou de forma absoluta (sem qualquer vinculação a índices). Nesse último caso, diferentes medidas podem ser utilizadas, dentre as quais: desvio padrão dos retornos passados; downside risk dos retornos passados; raiz quadrada da semivariância dos retornos passados; e valor em risco.

O denominado VAR (value at risk) "mede a pior esperada ao longo de determinado intervalo de tempo, sob condições normais de mercado e dentro de determinado nível de confiança" (JORION, 1998).

O VAR, não considera desvios decorrentes de mudanças inesperadas nas variáveis analisadas, em face disso torna-se imprescindível realizá-lo juntamente com a elaboração de cenários extremos visando captar um espaço maior de probabilidades.

Entre as metodologias utilizadas para o cálculo do VAR, destaca-se a Simulação Monte Carlo. A Simulação Monte Carlo é o resultado do trabalho de VON NEUMAN e ULAN desenvolvido em 1940 objetivando solucionar problemas de blindagem de reatores nucleares. (NAYLOR at alii, 1966).

Morse (1986) define a Simulação Monte Carlo como um tipo especial de simulação utilizada em modelos envolvendo eventos probabilísticos. O nome Monte Carlo se dá porque utiliza um processo aleatório, tal como um lançamento de dados ou girar uma roleta, para selecionar cada uma das variáveis.

Pulido et al. (1992) descreve a Simulação Monte Carlo como um método artificial utilizado na solução de experimentos aleatórios onde se tem conhecimento das distribuições de probabilidade das variáveis envolvidas, podendo desse modo determinar o nível de confiabilidade de sistemas estruturais.

A Simulação Monte Carlo é um método bastante usado para quantificar volatilidades em áreas como finanças, química, engenharia elétrica entre outras.

Novo e Lauro (2011) e Winnischofer et al. (2010) utilizaram a SMC para as curvas de decaimento dos estados excitados das moléculas luminescentes na presença de moléculas supressoras, de acordo com o mecanismo de supressão de energia eletrônica de Perrin.

Um dos primeiros estudos a utilizar a Simulação Monte Carlo em análise de investimentos foi o artigo Risk Analysis in Capital Investiment do autor David b. Hertz.

Segundo Jané (2003), o processo de simulação por si só não realiza a avaliação de probabilidades para a variável de saída desejada, baseada em relações matemáticas préestabelecidas. Por isso, sempre deverá estar agregado à técnica de simulação um método responsável por analisar as distribuições de probabilidades geradas e quantificar os riscos. 
Tratando de análise de investimentos, destaca-se o VPL como método mais utilizado, sendo este determinístico. A sua fórmula comumente conhecida encontra o valor correspondente à soma dos resultados anuais descontados a uma taxa mínima de atratividade menos o valor do investimento inicial. Securato (1996) apresenta a fórmula do VPL como sendo:

$\mathrm{VPL}=\Sigma \mathrm{Fj} /(1+\mathrm{i}) \mathrm{j}$

Onde:

Fj: é o fluxo de caixa no período j.

i: é a taxa de desconto correspondente à taxa mínima de atratividade do empreendimento.

Por se tratar de um método determinístico, ou seja, que parte de que todos os valores das variáveis de influência são conhecidos, acaba apresentando uma grande incerteza em relação à exatidão dos resultados. Isso se dá porque o fluxo de caixa é composto por variáveis altamente influenciáveis por fatores externos, tais como a situação econômica do país, mudança no perfil de consumo da população, equilíbrio entre oferta e demanda de um produto no mercado entre outros. Um bom exemplo é a variável receita, há uma grande dificuldade em determinar um valor projetado exato devendo sempre levar com consideração um desvio.

O autor Fulano Jané (2003) descreve de maneira simplificada os passos do método conforme a Figura 9.

Figura 9: Processo da Simulação Monte Carlo

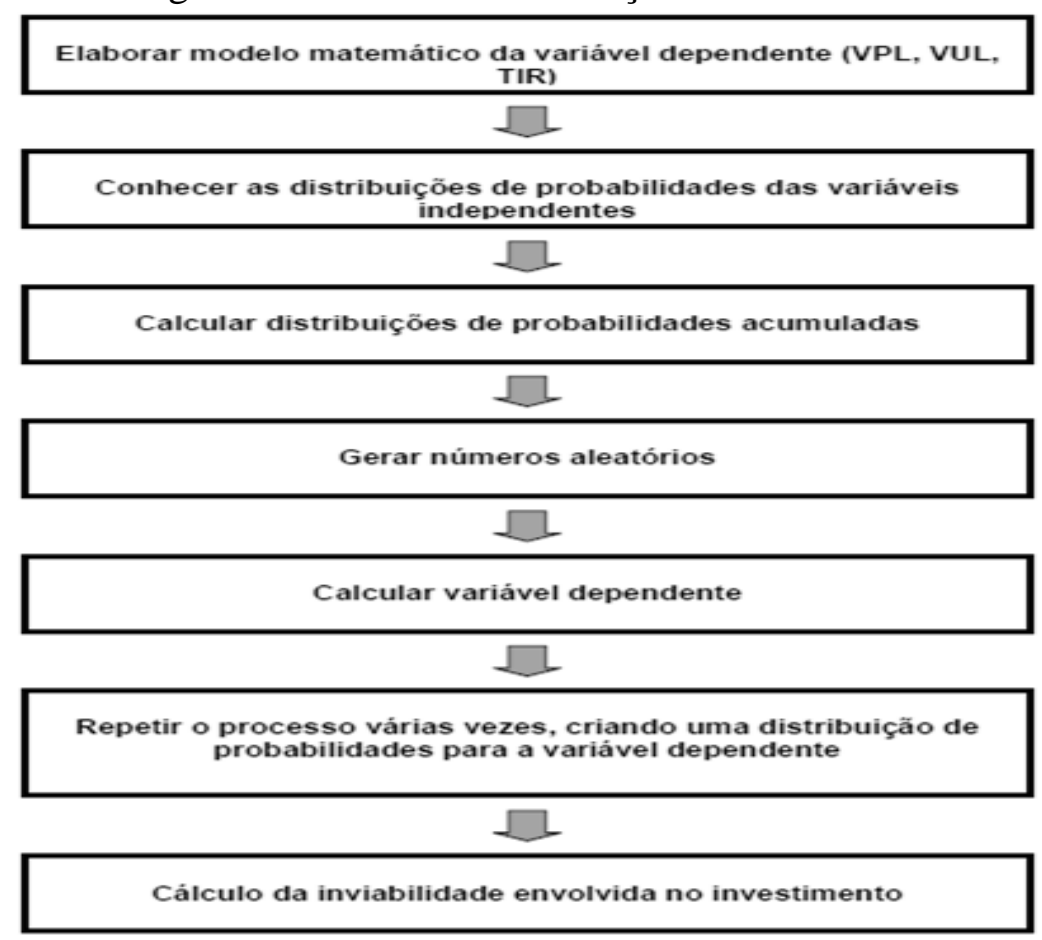

Fonte: Jané (2003).

Os passos requerem detalhes específicos a serem detalhados. Na primeira etapa da aplicação da Simulação Monte Carlo é preciso montar um fluxo de caixa ou uma DRE (Demonstração 
do Resultado do Exercício), onde o VPL é uma variável dependente das demais: receitas, custos, impostos etc.

No segundo passo é preciso avaliar o comportamento de cada uma das variáveis para identificar quais apresentam relevante nível de incerteza quanto aos seus resultados, para isso, é possível testar a sua distribuição baseada em resultados históricos. Há variáveis mais incertas que podem ser observadas mediante três cenários de ocorrência e outras menos voláteis que podem ser avaliadas com apenas dois cenários, conforme Quadro 2.

Quadro 2: Premissas da simulação

\begin{tabular}{|l|l|l|l|l|}
\hline \multicolumn{3}{|c|}{ Variável mais incerta } & \multicolumn{2}{l|}{ Variável menos incerta } \\
\hline Pessimista & Realista & Otimista & $\begin{array}{l}\text { Cenário Pessimista } \\
\text { ou Provável }\end{array}$ & Cenário Otimista \\
\hline $\begin{array}{l}\text { Valor } \\
\text { Mínimo }\end{array}$ & $\begin{array}{l}\text { Valor } \\
\text { Intermediário }\end{array}$ & $\begin{array}{l}\text { Valor } \\
\text { Máximo }\end{array}$ & Valor Mínimo & Valor Máximo \\
\hline Distribuição Triangular & \multicolumn{2}{|l|}{ Distribuição Uniforme } \\
\hline
\end{tabular}

Ao chegar às possibilidades de ocorrência das rubricas de risco é possível observar que as mesmas deixaram de ser um valor determinístico e passaram a ser uma variável estocástica, ou seja, segue uma distribuição de probabilidades de ocorrência. De modo mais simples, assume-se que é possível ocorrer qualquer valor que esteja dentro dos intervalos que caracterizam os cenários construídos.

Essa alteração nas rubricas de risco gerará um reflexo no resultado do VPL, quando se trabalha com números determinísticos obtém-se um valor determinístico de VPL. No caso da Simulação Monte Carlo, haverá rubricas de risco aleatórias que gerarão um VPL probabilístico.

No processo de simulação os números que estão dentro dos intervalos criados pelos cenários serão selecionados aleatoriamente mediante " $n$ " repetições, cada valor selecionado irá gerar um valor de VPL diferente que será captado e armazenado na amostra.

Para Pulido et al. (1992) a sua utilização exige a geração de $N$ amostras independentes no vetor das variáveis aleatórias $X$ obtidas a partir da função densidade de probabilidade conjunta $\mathrm{f}_{\mathrm{x}}(\mathrm{X})$. A probabilidade de falha pode ser expressa, utilizando o método a partir da integral definida em (14):

$P f=\int G x(X) \leq 0 \quad \int \ldots \int f x(X) d X$

Ou em (5):

$P_{f}=\int_{\forall X} \int \ldots \int I[G X(X) \leq 0] f x(X) d X$

Onde $\mathrm{G}_{\mathrm{x}}(\mathrm{X})$ é a função de falha, que relaciona as variáveis envolvidas na análise, e a função I [.] é um indicador que corresponde aos valores apresentados em (16):

$$
\begin{aligned}
I[.]= & 1 \text { se } G x(X)>0 \\
& 0 \text { se } G x(X)<0
\end{aligned}
$$


Desse modo pode-se reescrever a expressão (15) como em (17):

$\mathrm{P}_{\mathrm{f}}=\sum_{\mathrm{i}=1}^{\mathrm{n}} \mathrm{I}\left[\mathrm{Gx}\left(\mathrm{x}^{\mathrm{i}}\right) \leq 0\right] \cdot \frac{1}{\mathrm{~N}} \sum \mathrm{I}[\mathrm{Gx}(\mathrm{xi}) \leq 0] \cdot(1 / \mathrm{n})$

Onde $\left(\mathrm{x}^{\wedge} \mathrm{i}\right)$ representa a i-ésima amostra do vetor das variáveis $\mathrm{X}$ geradas a partir da função densidade de probabilidade $\mathrm{f}_{\mathrm{x}}(\mathrm{X})$. $\mathrm{O}$ valor de $\mathrm{P}_{\mathrm{f}}$ passa ser determinado pela expressão :

Pf $=\left(n^{o}\right.$ de simulações em que $\left.G_{x}(X) \leq 0\right) / n$

Com base na amostra dos valores de VPL resultantes das simulações será possível calcular as probabilidades de resultados para o indicador VPL.

A variância para os valores de probabilidade falha é expressa em (19):

$\operatorname{VAR}(\mathrm{Pf})=\mathrm{Pf} \cdot \frac{(1-\mathrm{Pf})}{\mathrm{N}} \cong \frac{\mathrm{Pf}}{\mathrm{N}}$

Para as estruturas usuais, a probabilidade de falha $\mathrm{P}_{\mathrm{f}}$ é pequena, geralmente da ordem de $10^{-3}$ a $10^{-5}$, e , como a sua variância é expressa de forma inversamente proporcional ao número total de simulações, o valor de $\mathrm{N}$ deve ser elevado para que se possa obter aproximações aceitáveis de $\mathrm{P}_{\mathrm{f}}$. Por esse motivo, o método de Monte Carlo é frequentemente utilizado para checar outras técnicas de aproximação.

O erro total é dado por $\epsilon=(3 \sigma) / \sqrt{ } \mathrm{N}$, onde $\sigma$ é o desvio padrão da variável aleatória e $\mathrm{N}$ é o número de iterações. Sendo assim, é possível obervar que quanto maior o número de iterações, menor será o erro.

Bruni, Famá e Siqueira (1998) realizaram um estudo demonstrando a aplicabilidade da SMC na análise de projetos de investimentos, desse modo demonstrou que em relação aos métodos de análise determinística usados atualmente para avaliar fluxos de caixa a SMC é mais robusta do que o VPL tradicional uma vez que consegue medir o risco. Para Securato (1996), o risco de um fluxo de caixa é dado por:

$\sqrt{ } \operatorname{VAR}[\operatorname{VPL}]=\sqrt{ } \Sigma[\operatorname{VAR}(\mathrm{Fj}) /(1+\mathrm{i}) 2 \mathrm{j}]$

O resultado gerado é um gráfico de distribuição de frequências no qual podem ser observadas também as respectivas probabilidades de ocorrência. 
Figura 10: Gráfico de distribuição de probabilidades

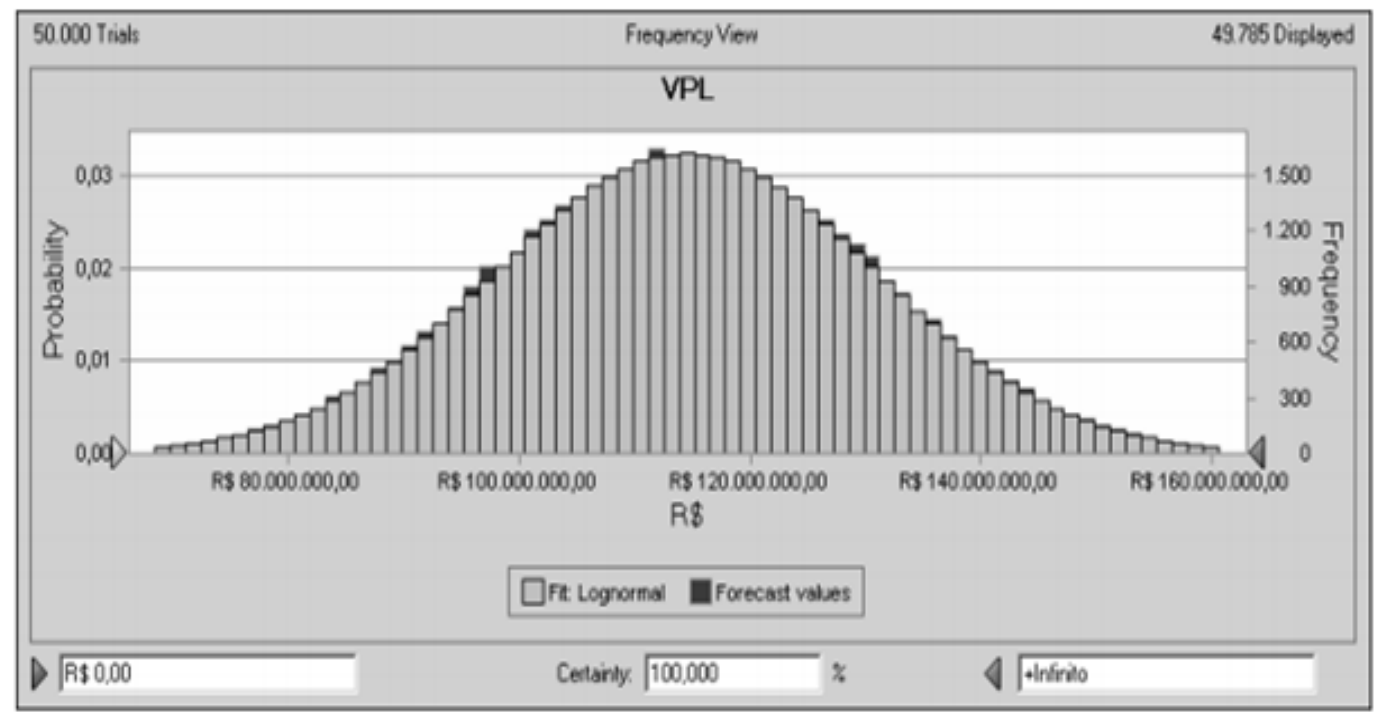

Fonte: Souza et al. (2015).

Spiegel (1993) afirma que se o número de elementos analisados for menor do que trinta, a aplicação do Teorema do Limite Central não resulta numa boa aproximação, portanto, o momento em que uma análise apresentar pelo menos 30 observações poderá ser considerado minimamente representativo.

Na Simulação Monte Carlo se emprega o princípio do Teorema do Limite Central, segundo Tabachnick \& Fidell (1996), quanto maior a amostra, maior será a chance de que as distribuições das médias das variáveis envolvidas estejam normalmente distribuídas. Logo, os efeitos da não normalidade das variáveis são reduzidos aumentando a robustez da análise.

Segundo Bruni, Famá e Siqueira (1998), o Teorema do Limite Central revela que para " $n$ " grande, a média e o desvio padrão amostrais convergem para a média e desvio padrão populacionais. Sendo assim, construindo um gráfico da média e do desvio padrão obtido versus número de simulações encontra-se que ocorre uma estabilização dos valores da média e do risco de um projeto.

Cantelmo e Ferreira (2007) avaliaram a performance do teste multivariado de normalidade de Shapiro-Wilk implementado no software "R" comparando o seu desempenho com os testes de assimetria e curtose de Mardia, utilizando a simulação Monte Carlo multivariado. Foram mensuradas e comparadas as taxas de erro tipo I e poderes dos testes. Os resultados concluíram que o teste de Shapiro-Wilk multivariado do programa $\mathrm{R}$, função mshapir.test do pacote mvnormtest, tem fraco desempenho (liberal) e não é recomendado para uso rotineiro.

Dias e Borges (2009) apresentaram um modelo computacional flexível orientado a objetos para avaliação da confiabilidade composta por sistemas de potência por Simulação Monte Carlo Sequencial e Não- Sequencial em sistemas eólicos. Os resultados comprovam a aplicabilidade do modelo desenvolvido e permite levantar várias conclusões sobre a importância da geração eólica nos índices de confiabilidade do sistema.

Reis (2010) utilizou a simulação Monte Carlo para desenvolver uma metodologia acurada de baixo custo para a determinação dos espectros primários dos campos de radiação utilizados em radioterapia a partir de medidas de transmissão em atenuadores de alumínio, cobre 
chumbo e acrílico, utilizando o método da transformada inversa de Laplace. A Simulação Monte Carlo apresentou-se como ferramenta indispensável na avaliação dos resultados para os diferentes materiais que caracterizam os feixes.

Silva e Cirillo (2010) buscaram determinar qual a melhor constante de afinidade (c1) que proporcione o melhor desempenho em um estimador pertencente à classe dos estimadores -E. Com esse objetivo, utilizou-se a Simulação Monte Carlo para determinar o valor mais apropriado para a constante de afinidade.

Saraiva, Tabosa e Costa (2011) utilizaram a Simulação Monte Carlo para elaborar uma metodologia de auxílio à tomada de decisões gerenciais. Este consiste em um modelo de cinco etapas construído a partir da integração de técnicas provindas da contabilidade gerencial e da pesquisa operacional aliada à Simulação Monte Carlo.

Oliveira, Cirillo e Borges (2011) utilizaram a Simulação Monte Carlo na estimação de curvas de isotermas de adsorção com o intuito que obter resultados que não sejam necessariamente lineares como apresentam os modelos tradicionalmente utilizados para esta finalidade, modelos de regressão Oswin e Halsey. Os resultados apontaram que a Simulação Monte Carlo apresenta resultados mais adequados.

Sánchez (2012) utilizou a simulação Monte Carlo com o código de simulação PENELOPE avaliar a ajustar a dosimetria de radiações em radiocirurgia estereotáxica e ressonância magnética nuclear.

\subsubsection{Análise de regressão linear}

Segundo Fávero et al. (2009) , a regressão linear tem como objetivo estudar a relação entre duas ou mais variáveis explicativas, que se apresentam na forma linear, e uma variável dependente métrica. Assim, um modelo geral de regressão linear pode ser escrito da seguinte forma:

$\mathrm{Y}=\alpha+\beta 1 * \mathrm{X} 1+\beta 2 * \mathrm{X} 2+\ldots+\beta \mathrm{n} * \mathrm{Xn}+\mathrm{u}$

Em que Y é o fenômeno (variável dependente métrica), $\alpha$ representa o intercepto (constante), $\beta \mathrm{k}(\mathrm{k}=1,2, \ldots, \mathrm{n})$ são os coeficientes de cada variável (coeficientes angulares), Xk são as variáveis explicativas (métricas ou dummies) e u é o termo do erro (diferença entre o valor real Y e o valor previsto de Y por meio do modelo para cada observação). O erro u, também conhecido por resíduo, representa possíveis variáveis $\mathrm{X}$ que não foram inseridas no modelo e que seriam boas candidatas as explicativas da variável Y.

Enquanto a regressão simples refere-se à existência de apenas uma variável explicativa $\mathrm{X}$, a regressão múltipla permite a inclusão de diversas variáveis para a explicação de determinado fenômeno.

Os parâmetros $\alpha$ e $\beta$ são desconhecidos, por isso é necessário estimá-los.O cálculo dos parâmetros $\alpha$ e $\beta$ é feito por meio das seguintes expressões:

$$
\mathrm{a}=\overline{\mathrm{Y}_{1}}-\overline{\mathrm{X}_{1}}
$$

em que a e b1 são os estimadores dos parâmetros $\alpha$ e $\beta 1$, 
$\bar{X}=\frac{1}{n} \sum_{\mathrm{i}=1}^{\mathrm{n}} \mathrm{Xi} \quad$ e $\quad \overline{\mathrm{Y}}=\frac{1}{\mathrm{n}} \sum_{\mathrm{i}=1}^{\mathrm{n}} \mathrm{Yi}$

Onde:

$\mathrm{b} 1=\frac{\sum_{\mathrm{i}=1}^{\mathrm{n}}(\mathrm{Xi}-\overline{\mathrm{X}})(\mathrm{Yi}-\overline{\mathrm{Y}})}{\sum_{\mathrm{i}=1}^{\mathrm{n}}(\mathrm{Xi}-\overline{\mathrm{X}})^{\wedge} 2}=\frac{\frac{1}{\mathrm{n}} \sum_{\mathrm{i}=1}^{\mathrm{n}}(\mathrm{Xi}-\overline{\mathrm{X}})(\mathrm{Yi}-\overline{\mathrm{Y}})}{\frac{1}{\mathrm{~N}} \sum_{\mathrm{i}=1}^{\mathrm{n}}(\mathrm{Xi}-\overline{\mathrm{X}})^{\wedge} 2}=\frac{\operatorname{cov}(\mathrm{X}, \mathrm{Y})}{\operatorname{Var}(\mathrm{X})}$

No caso da regressão linear múltipla, de forma análoga à regressão simples, o parâmetro $\alpha$ é calculado por meio de seu estimador a, da seguinte forma:

$$
\mathrm{a}=\overline{\mathrm{Y}}-\mathrm{b} 1 . \overline{\mathrm{X}} 1-\ldots-\mathrm{bn} \cdot \overline{\mathrm{X}} \mathrm{ni}
$$

Em que $b_{k}(K=1,2, \ldots, n)$ representa os estimadores dos betas para as $n$ variáveis $\mathrm{X}$ utilizadas no modelo. Já a estimação dos betas para a regressão múltipla segue o mesmo procedimento da regressão linear simples, mas é feito por etapa e por variáveis. Para a ilustração, apresentamos a estimação de $\beta 1$ (b1) para regressão múltipla, de acordo como segue:

$\mathrm{b} 1=\operatorname{cov}(\mathrm{X} 1, \mathrm{Y}) \cdot(\operatorname{Var}(\mathrm{X} 2)-\operatorname{cov}(\mathrm{X} 2, \mathrm{Y}) \cdot \operatorname{cov}(\mathrm{X} 1, \mathrm{X} 2) / \operatorname{Var}(\mathrm{X} 1) \cdot \operatorname{Var}(\mathrm{X} 2)-[\operatorname{cov}(\mathrm{X} 1, \mathrm{X} 2)] 2$

Para mais de duas variáveis basta repetir o procedimento, obtendo ao final uma equação de estimativa.

$\hat{Y}=a+b 1^{*} x 1+b 2^{*} X 2+\ldots .+b n^{*} x n+u$

No entanto, é preciso medir o poder explicativo do modelo, ou seja, o quanto as variáveis $\mathrm{X}$ explicam a variável Y. Para isso é preciso entender os principais conceitos.

A soma total dos quadrados (STQ) mostra a variação de $\mathrm{Y}$ em torno da própria média. A soma dos quadrados da regressão ( $\mathrm{SQR}$ ) oferece a variação de $\mathrm{Y}$ considerando as variáveis utilizadas no modelo e, por fim, a soma dos quadrados dos resíduos (SQU) apresenta a variação de Y que não é explicada pelo modelo elaborado. Então:

$\mathrm{STQ}=\mathrm{SQR}+\mathrm{SQU}$

De modo que:

$Y-\bar{Y}=(\hat{y} i-\bar{Y})+(Y i-\hat{y} i)$

Em que Yi equivale ao valor de cada observação de $\mathrm{Y}, \overline{\mathrm{Y}}$ é a média de $\mathrm{Y}$ e ŷi representa o valor ajustado da reta de regressão para cada observação. Logo, temos que:

$(Y \mathrm{i}-\bar{Y})=$ desvio dos valores de cada observação total em relação à média;

$(\hat{y}-\bar{Y})=$ desvio dos valores da reta de regressão para cada observação em relação à média;

$(Y i-\hat{y} i)=$ desvio dos valores de cada observação em relação à reta de regressão. 
De onde vem que:

$\sum_{\mathrm{i}=1}^{\mathrm{n}}(\mathrm{Yi}-\overline{\mathrm{Y}})^{2}=\sum_{\mathrm{i}=1}^{\mathrm{n}}(\hat{\mathrm{y} i}-\overline{\mathrm{Y}})^{2}+\sum_{\mathrm{i}=1}^{\mathrm{n}}(\mathrm{Yi}-\hat{\mathrm{y} i})^{2}$

$\sum_{\mathrm{i}=1}^{\mathrm{n}}(\mathrm{Yi}-\overline{\mathrm{Y}})^{2}=\sum_{\mathrm{i}=1}^{\mathrm{n}}(\hat{\mathrm{y} i}-\overline{\mathrm{Y}})^{2}+\sum_{\mathrm{i}=1}^{\mathrm{n}}(\mathrm{u})^{2}$

Stock e Watson definem o $\mathrm{R}^{2}$ como "a fração da variância da amostra de Yi explicada (ou prevista) pelos regressores". Este mede o percentual de dados analisados que podem ser explicados pelo modelo. Ou seja, Fávero et al. (2009) mostra o quanto o comportamento das variáveis $\mathrm{X}$ explicam a variação de $\mathrm{Y}$, esta é dada por:

$\mathrm{R}^{2}=\frac{\mathrm{SQR}}{\mathrm{SQT}}=\frac{\operatorname{Var}(\hat{\mathrm{y}})}{\operatorname{Var}(\mathrm{Y})}=1-\frac{\operatorname{Var}(\mathrm{u})}{\operatorname{Var}(\mathrm{Y})}$

E, portanto:

$\mathrm{R}^{2}=\left(\frac{\sum_{\mathrm{i}=1}^{\mathrm{n}}(\mathrm{Xi}-\bar{X}) \cdot(\mathrm{Yi}-\bar{Y})}{\sqrt{\sum_{\mathrm{i}=1}^{\mathrm{n}}(\mathrm{Xi}-\bar{X})^{2} \cdot \sum_{\mathrm{i}=1}^{\mathrm{n}}(\mathrm{Yi}-\overline{\mathrm{Y}})^{2}}}\right)^{2}$

O $\mathrm{R}^{2}$ pode variar entre 0 e 1 ( 0 a $\left.100 \%\right)$, porém é praticamente impossível a obtenção de um $\mathrm{R}^{2}$ igual a 1 , em outras palavras, se $\mathrm{o} \mathrm{R}^{2}$ for igual a 1 não haverá resíduos para cada uma das observações da amostra em estudo.

Quando há o intuito de comparar o coeficiente de ajuste $\left(\mathrm{R}^{2}\right)$ entre dois modelos ou entre um mesmo modelo com tamanhos de amostra diferentes, faz-se necessário o uso do $\mathrm{R}^{2}$ ajustado (Adjusted $\mathrm{R}^{2}$ ), que é uma medida do $\mathrm{R}^{2}$ da regressão MQO ajustada pelo número de graus de liberdade, uma vez que a estimativa amostral de $\mathrm{R}^{2}$ tende a superestimar o parâmetro populacional. A expressão do $\mathrm{R}^{2}$ ajustado é:

$\mathrm{R}^{2}$ ajust $\left.=1-[(\mathrm{N}-1) / \mathrm{N}-\mathrm{K})\right] \cdot(1-\mathrm{R} 2)$

Em que $n$ é o tamanho da amostra e $K$ o número de parâmetros de regressão (número de variáveis explicativas mais o intercepto). Quando o número de observações é muito grande, o ajuste pelos graus de liberdade torna-se desprezível, porém quando há um número significativamente diferente de variáveis $\mathrm{X}$ para duas amostras também diferentes, deve-se utilizar o $\mathrm{R}^{2}$ ajustado para a elaboração de comparações entre os modelos.

\subsubsection{Teste de hipóteses.}

Os testes de hipóteses são uma forma de fazer constatações acerca de parâmetros populacionais, podendo ser aceitas ou não.

Os principais fatores que devem ser feitos em um teste de hipóteses são:

1- Formulas as hipóteses a serem testadas

2- Definir o intervalo de confiança

3- Aceitar ou rejeitar a hipótese formulada com base no $p$-value

A hipótese nula (H0) é a hipótese a ser testada podendo rejeitá-la ou rejeitá-la. Em análise de regressão linear simples ou multivariada verificasse a seguinte hipótese. 
$\mathrm{H} 0: \mathrm{b}=0$

$\mathrm{H} 1: \mathrm{b} \neq 0$

Caso o b seja estatisticamente diferente de zero, rejeitasse a hipótese nula (H0) e admite-se a hipótese alternativa (H1).

Com é possível incorrer em dois tipos de erro, erro do tipo I e erro do tipo II. O Quadro 3 sintetiza os dois tipos de erro.

Quadro 3 : Tipos de erro.

\begin{tabular}{|l|l|l|}
\hline Decisão & H0 verdadeira & H0 falsa \\
\hline Aceito H0 & OK & Erro tipo II \\
\hline Rejeito H0 & Erro tipo I & Ok \\
\hline
\end{tabular}

Costuma-se utilizar um intervalo de confiança de $90 \%, 95 \%$ ou $99 \%$, ou seja, valores $\alpha$ de $10 \%, 5 \%$ e $1 \%$ respectivamente. O teste do $p$-value deve indicar um número menor do que o $\alpha$ referente ao intervalor de confiança escolhido, $p$-value $<\alpha$.

\subsubsection{Estatística $t$ de Student}

Segundo Fávero et al (2009), o deste $t$ de student para uma amostra é aplicado quando não se conhece a variância populacional $\left(\sigma^{2}\right)$ e se tem como objetivo testar se uma média populacional assume ou não determinado valor. $\mathrm{O}$ teste exige que determinada variável $\mathrm{T}$ em estudo tenha distribuição normal padrão $\mathrm{T} \sim \mathrm{N}(0,1)$.

O procedimento adotado para este está detalhado a seguir:

1- Fixar a hipótese nula $\mathrm{H} 0$ e a hipótese alternativa H1. Para um teste bilateral, a hipótese nula H0 afirma que uma amostra provém de uma população com uma média $(\mathrm{M} \neq \mu 0)$.

2- Fixar o nível de significância $\alpha$ do teste.

3- A distribuição amostral depende do tamanho de N:

a) $\mathrm{Se} \mathrm{N} \leq 30$, a variável teste escolhida será $\mathrm{T}$ (distribuição $t$ de student) com $v=\mathrm{n}-1$ graus de liberdade.

4- Para $\mathrm{N} \leq 30$, fixar a região crítica com o auxílio da tabela de distribuição $t$ de student (Tabela B dos anexos).

5- O valor real da variável T depende do tamanho de $\mathrm{N}$ :

a) Quando $\mathrm{N} \leq 30$ o valor da estatística é:

Tcal $=(\bar{X}-\mathrm{M} 0) /\left(\sqrt{\mathrm{S}^{\prime}} 2 / n\right)$

Em que:

$\bar{X}=$ valor da hipótese nula;

м0 = valor da hipótese nula;

$n=$ tamanho da amostra;

Página 48 
$\mathrm{S}^{, 2}=$ variância corrigida, sendo que;

$\mathrm{S}^{, 2}=(\mathrm{n} / \mathrm{n}-1) * \mathrm{~S}^{2}$

b) Quando N > 30, o valor da estatística é:

Tcal $=(\bar{X}-\mu 0) /(\sqrt{S} 2 / n)$

Em que:

$S^{2}=$ variância da amostra .

Conclusão: se o valor da estatística pertencer à região crítica, isto é, se $T_{\text {cal }}<-t_{c}$ ou $T_{c a l}>t_{c}, o$ teste oferece condições à rejeição da hipótese nula. $\mathrm{Se}-\mathrm{t}_{\mathrm{c}} \leq \mathrm{T}_{\mathrm{cal}} \leq \mathrm{t}_{\mathrm{c}}$, não se rejeita $\mathrm{H} 0$.

\subsubsection{Teste $\mathbf{F}$}

Conforme Fávero (2009), o teste F propicia a verificação da significância do modelo, uma vez que a hipótese nula e alternativa são:

$\mathrm{H} 0: \beta 1=\beta 2=\ldots=\beta \mathrm{k}=0$

H1: existe pelo menos um $\beta \mathrm{i} \neq 0$

Este teste propicia ao pesquisador uma verificação inicial sobre a existência do modelo que está sendo proposto, uma vez que, se todos os betas forem estatisticamente iguais a 0 , o comportamento de alteração de cada uma das variáveis explicativas não influenciará em absolutamente nada o comportamento da variável dependente. A estatística $F$ é a seguinte expressão:

$\mathrm{F}=[\mathrm{SQR} /(\mathrm{K}-1)] /[\mathrm{SQU} /(n-k)]$

Em que SQR é a soma dos quadrados da regressão, $k$ é o número de parâmetros da regressão, SQU á soma do quadrado dos resíduos, $n$ é o tamanho da amostra e $(k-1)$ variáveis $(n-\mathrm{k})$ observações são os ajustes dos graus de liberdade da distribuição F. Desta forma, pode-se obter a estatística $\mathrm{F}$ por meio do $\mathrm{R}^{2}$, da seguinte forma:

$\mathrm{F}=[\mathrm{SQR} /(\mathrm{K}-1)] /[\mathrm{SQU} /(n-k)]=\left[\mathrm{R}^{2} /(k-1)\right] /\left[\left(1-\mathrm{R}^{2}\right) /(n-k)\right.$

Desse modo o teste $\mathrm{F}$ avalia a significância conjunta das variáveis explicativas, porém não define qual ou quais das variáveis explicativas consideradas são estatisticamente significativas ou não para influenciar o comportamento da variável Y.

\subsubsection{Problema da Multicolinearidade}

Segundo Hair (2005), existem diversos fatores que podem influenciar na busca do melhor modelo de regressão, que inclui a seleção de variáveis dependentes e independentes. As suposições referentes à análise de regressão (normalidade, linearidade, homocedasticidade e independência dos termos de erro) devem ser testadas para as variáveis individuais e se todas forem atendidas, o modelo deverá ser estimado. Após a obtenção dos resultados, faz-se análises diagnósticas no sentido de verificar se o modelo geral atende às suposições de regressão e que nenhuma observação tenha influência excessiva sobre os dados. Ao final, os resultados são validados para garantir generalização para a população. 
Hair (2005) afirma que, além dos efeitos na explicação, a multicolinearidade pode ter sérios efeitos nas estimativas dos coeficientes de regressão e na aplicabilidade geral do modelo estimado.

Algumas indicações da presença de multicolinearidade são:

1- Valores altos do coeficiente de correlação;

2- Grandes alterações nas estimativas dos coeficientes de regressão, quando uma variável independente for adicionada ou retirada do modelo, ou quando uma observação for alterada ou eliminada;

3- A rejeição da hipótese $\mathrm{H} 0: \mathrm{b} 1=\mathrm{b} 2=\ldots=\mathrm{bk}=0$, mas nenhuma rejeição das hipóteses H0: $b i=0, i=1,2, \ldots, k$, sobre os coeficientes individuais de regressão;

4- Obtenção de estimativas para os coeficientes de regressão com sinais algébricos contrários àqueles que seriam esperados a partir de conhecimentos teóricos disponíveis ou de experiências anteriores sobre o fenômeno estudado e

5- Obtenção de intervalos de confiança com elevados amplitudes para os coeficientes de regressão, associados a variáveis independentes importantes.

As duas formas de detecção de multicolinearidade mais conhecidas são o fator de Inflação de Variância (VIF) definido pela equação $F(\beta$ estimado $)=i / 1-R_{j}^{2}$. Esta é uma medida do grau em que cada variável independente é explicada pelas demais variáveis independentes. Quanto maior for o fator de inflação da variância, mas severa será a multicolinearidade. Johson e Wichern (1988) e Hair (2005) sugerem que se qualquer fator de inflação da variância exceder 10, então a multicolinearidade causará efeitos nos coeficientes de regressão.

Hair (2005) destaca as seguintes recomendações:

- Excluir uma ou mais variáveis independentes altamente correlacionadas e identificar outras variáveis independentes para ajudar na previsão. Esse procedimento deve ser feito com cautela, pois, neste caso, há o descarte de informações, contidas nas variáveis removidas;

- Usar o modelo com variáveis independentes altamente correlacionadas apenas para previsão, ou seja, não interpretar os coeficientes de regressão;

- Usar as correlações simples entre cada variável independente e dependente

- Usar um método ais sofisticado de análise como a regressão Bayesiana (ou um caso especial - regressão ridge) ou a regressão sobre componentes principais para obter um modelo que reflita mais claramente os efeitos das variáveis independentes.

\subsubsection{Teste RESET de Ramsey}

O teste RESET de Ramsey (1969) consiste em verificar se a inclusão de uma função não linear no modelo estimado exerce impacto significativo na estimativa da variável dependente. $\mathrm{O}$ teste mais usual é o que quadrado e cubo. Este teste insere-se Y estimado ao quadrado e Y estimado ao cubo. 
O teste RESET de Ramsey consiste em verificar se a inclusão de uma função não linear no modelo estimado exerce impacto significativo na estimativa da variável dependente. $\mathrm{O}$ primeiro passo do teste é estimar o modelo de explicação.

$\mathrm{Yi}=\beta 0+\beta 1 . \mathrm{X} 1+\beta 2 . \mathrm{X} 2+\ldots+\beta \mathrm{k} \cdot \mathrm{Xk}+\mathrm{u}$

O teste mais usual é o de quadrado e cubo. Este teste insere-se $\hat{Y} 2$ e $\hat{Y} 3$ na equação originalmente estimada. (GUJARATI,2000).

$$
\mathrm{Yi}=\beta 0+\beta 1 . \mathrm{Xi1}+\beta 2 . \mathrm{Xi} 2+\beta 3 . \hat{Y}^{2}+\beta 4 . \hat{Y}^{3}+\mathrm{u}
$$

A partir da inserção dos termos quadrático e cúbico é realizado o teste $\mathrm{t}$ de student e o teste $\mathrm{F}$ para verificar se a nova equação é estatisticamente significante. Para tais efeitos, assume-se que $\mathrm{H} 0: \beta 3 \mathrm{e} / \mathrm{ou} \beta 4=0$ e $\mathrm{H} 1=\beta 3$ e $/$ ou $\beta 4 \neq 0$.

É admitido um outro deste $\mathrm{R}^{2}$ com base em uma relação com o $\mathrm{R}^{2}$ antigo. Desse modo calcula-se o teste $\mathrm{F}$, conforme a equação 46.

$\mathrm{F}=\left[\mathrm{R}^{2}\right.$ novo $-\mathrm{R}^{2}$ velho) / (número de novos regressores) $] /\left[\left(1-\mathrm{R}^{2}\right.\right.$ novo $) /(\mathrm{n}-$ número de parâmetros no novo modelo)

A rejeição da hipótese nula indica que a equação originalmente estimada está corretamente especificada, caso a hipótese nula aceitada é preciso testar a inclusão outras variáveis no modelo estimado ou verificar a significância estatística de outras combinações de variáveis.

Signor (1999) buscou equacionar o consumo de energia de edifícios de escritórios climatizados artificialmente para climas de 14 capitais brasileiras. Foram utilizadas regressões lineares múltiplas para cada cidade estudada, correlacionando o seu gasto energético anual a diversas variáveis arquitetônicas, construtivas e climáticas. Os resultados indicaram forte grau de correlação entre estes dois tipos de variáveis com um intervalo de confiança de $99 \%$.

A análise de regressão linear vem sendo utilizada em vários estudos acadêmicos, Latorre e Cardoso (2001) apresentaram o modelo de regressão linear como um dos principais métodos de análise de séries temporais.

Back (2001) utilizou a regressão linear para identificar tendências anuais da temperatura e precipitação pluvial com base em uma série histórica de 1924 a 1998. Os resultados indicaram que houve tendência significativa no aumento da precipitação pluvial total anual, e da precipitação pluvial total no quarto trimestre.

Nakamura et al (2007) utilizaram a regressão linear para fazer uma investigação sobre os fatores determinantes da estrutura de capital das companhias abertas que atuam no mercado brasileiro. Embasado na teoria do Trade-off , conclui-se que existe uma estrutura ótima de capital, perseguida pelos administradores, ao decidir entre benefícios da dívida (fiscais e disciplinares) e seus custos ( de falência, de agência e de flexibilidade).

Canciam (2013) estimou a energia de ativação de fluxo dos ácidos oleico e palmítico entre 70 e $100^{\circ} \mathrm{C}$, os valores da energia de fluxo foram determinados a partir da análise de regressão linear dos dados da viscosidade em função da temperatura. Em todos os casos estudados, os 
coeficientes de correlação foram próximos da unidade, classificando a correlação linear como muito forte.

Souza et al (2015) utilizaram a regressão linear para medir a relação entre o PIB da construção civil e o PIB nacional. Os resultados apontaram que o setor de construção civil está muito atrelado às oscilações do PIB, as representações numéricas denunciam que os investimentos em infraestrutura proporcionam e alavancam o crescimento dos outros setores e consequentemente o PIB. 
4. APLICAÇÃo DO MODELO DE PORTER (1979) NA ANÁLISE dOS INFORTÚNIOS FINANCEIROS DA INDÚSTRIA BRASILEIRA DE TRANSPORTE AÉREO DE PASSAGEIROS

4.1 Agentes da indústria brasileira de transporte aéreo doméstico de passageiros

O primeiro ponto que deve ser avaliado em uma indústria é a relação existente entre os atores que a compõem.

A indústria brasileira de transporte aéreo de passageiros é composta por várias instituições públicas, privadas e de capital misto que desempenham um relevante papel.

Partindo das companhias aéreas como ponto inicial de análise existem atores que desempenham papéis em três esferas: suprimento, complementar e regulatória conforme a Figura 11. 
Figura 11: Indústria brasileira de transporte aéreo de passageiros

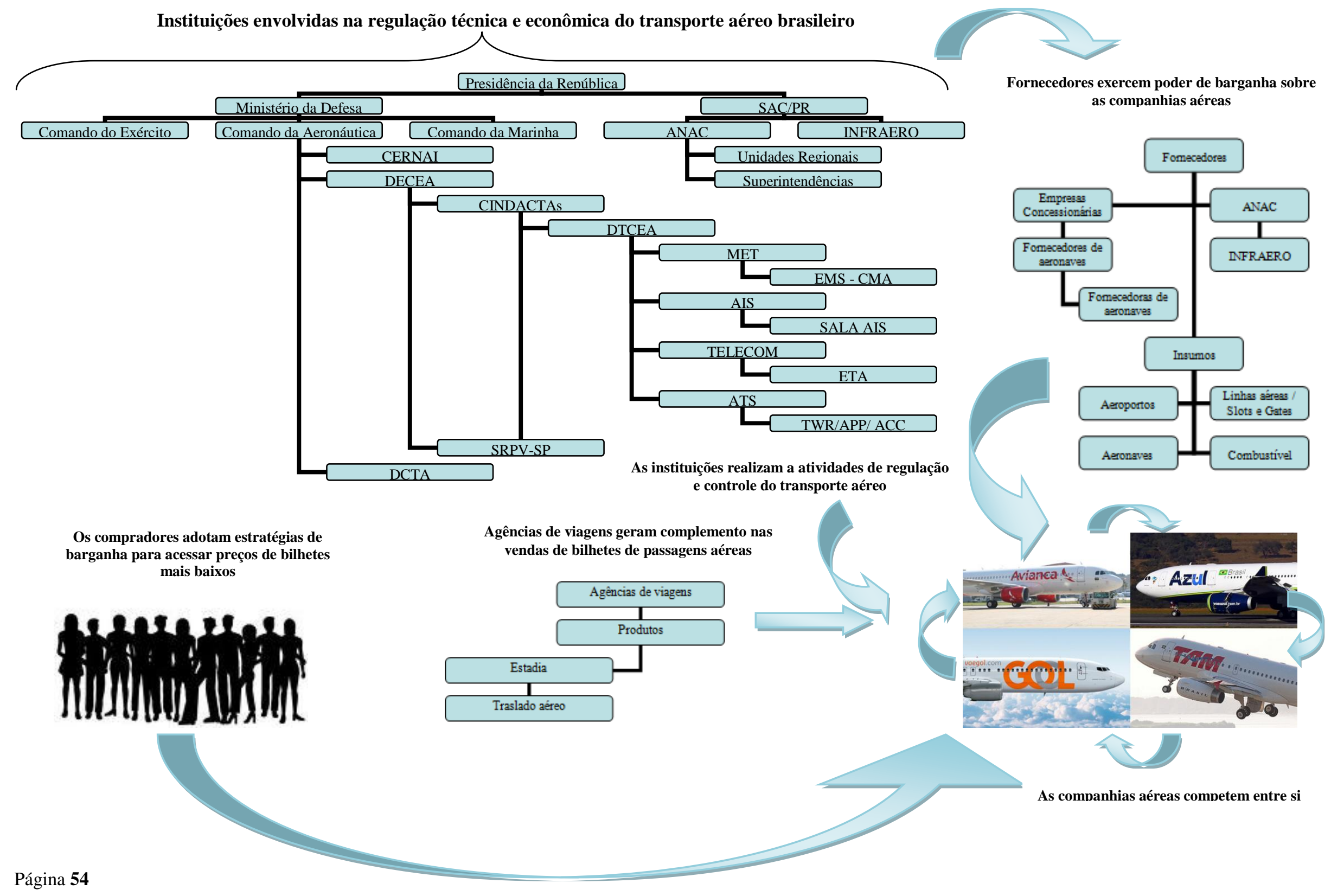


Fonte: Elabora pelo autor a partir de fotos de Runway News (2016) e Can Stock Photo (2016).

A figura 11 mostra as relações existentes entre os atores que se relacionam direta ou indiretamente com as companhias aéreas brasileiras.

O primeiro ponto a ser observado é que os principais insumos das companhias aéreas são: os aeroportos, linhas aéreas, aeronaves e combustível. Os atores responsáveis pelo fornecimento de cada um deles estão elencados abaixo:

- Aeroportos - a manutenção da infraestrutura aeroportuária é de responsabilidade da INFRAERO sendo esta a detentora dos principais aeroportos brasileiros. No entanto, há alguns aeroportos que foram concedidos e o investimento em infraestrutura passou a ser realizado por empresas privadas. Nesse contexto, a Agência Nacional de Aviação Civil (ANAC) passou a ter uma importante atuação por ser o agente regulador dos processos de concessão.

Segundo a SAC (2015), o programa de concessões aeroportuárias teve início em 2011. Até o momento, seis já foram concedidos para a iniciativa privada: Aeroporto Internacional Aluízio Alves - São Gonçalo do Amarante/RN, Aeroporto Internacional Presidente Juscelino Kubitschek - Brasília/DF, Aeroporto Internacional Tancredo Neves- Confins/MG, Aeroporto Internacional Antônio Carlos Jobim/ Galeão - Rio de Janeiro/RJ, Aeroporto Internacional Governador André Franco Montoro - Guarulhos/ SP e Aeroporto Internacional Viracopos Campinas/SP. Ainda está prevista a realização de mais três concessões de aeroportos: Aeroporto Internacional Salgado Filho - Porto Alegre/RS, Aeroporto Internacional Hercílio Luz - Florianópolis/SC e Aeroporto Internacional Deputado Luís Eduardo Magalhães Salvador/BA e Aeroporto Internacional Pinto Martins - Fortaleza/ CE.

- Linhas aéreas - cabe também à ANAC regular as concessões e autorizações para operar nas linhas aéreas. A agência realiza a análise dos pedidos e julga de forma discricionária visando tomar decisões que evitem competições ruinosas para o setor.

- Aeronaves - as aeronaves são fornecidas por empresas privadas, atualmente no Brasil operam aeronaves de apenas sete fornecedores. Isso se dá porque as companhias deixaram de operar com aeronaves McDonnel Douglas.

- Combustível - o combustível das aeronaves é o querosene, há apenas três empresas fornecedoras na indústria: Petrobrás, Raízen e Air BP. Atualmente, as participações de mercado das empresas Shell/Sabba e Cosan passaram a ser representadas pela Raízen, joint venture criada por ambas as empresas. (ANP, 2013).

A jusante das companhias aéreas observa-se o papel complementador das agências de viagem. Pode-se afirmar que agências de turismo são complementadoras das companhias aéreas.

As agências de turismo se beneficiam das vendas de passagens aéreas, isso porque oferecem pacotes de viagem (estadia + traslado), o que dá certa comodidade ao consumidor.

Por outro lado, as companhias aéreas se beneficiam em função das vendas realizadas pelas agências de viagem.

Em relação ao organograma apresentado pela Figura 11. O setor tem como instituição máxima a Presidência da República que detém dois assessores diretos, a Secretaria de Aviação Civil (SAC) e o Ministério da Defesa. 
A Secretaria de Aviação Civil (SAC), é uma secretaria com status de ministério criada por meio da lei $\mathrm{n}^{\mathrm{o}}$ 1246/2011 com o propósito de coordenar e supervisionar ações voltadas para o desenvolvimento estratégico do setor da aviação civil e da infraestrutura aeroportuária e aeronáutica no Brasil. Antes desenvolvido pelo Ministério da Defesa (SAC, 2015). Esta detém duas instituições públicas diretamente vinculadas, Agência Nacional de Aviação Civil (SAC) e Empresa Brasileira de Infraestrutura Aeroportuária (INFRAERO).

A Agência Nacional de Aviação Civil (ANAC) é uma autarquia especial com independência administrativa, personalidade jurídica própria, patrimônio e receitas próprias para executar atividades típicas da Administração Pública, que requerem, para seu melhor funcionamento, gestão administrativa e financeira descentralizada. Assim sendo "pode diversificar-se das repartições públicas para adaptar-se às exigências específicas dos serviços que lhe são cometidos" (ANAC, 2015). Entre seus poderes, destacam-se:

- Outorgar concessões de serviços e de infraestrutura aeronáutica e aeroportuária;

- Regular essas concessões;

- Aprovar planos diretores dos aeroportos;

- Regular as atividades de administração e exploração de aeródromos, inclusive as exercidas pela Empresa Brasileira de Infraestrutura Aeroportuária (INFRAERO).

Os seus atos administrativos visam: manter a continuidade da prestação do serviço público em nível nacional, zelar pelo interesse dos usuários, cumprir a legislação pertinente por ela regulado, considerados, em especial, o Código Brasileiro de Aeronáutica, a Lei das Concessões, a Lei Geral das Agências Reguladoras e a Lei de Criação da ANAC (ANAC, 2015).

Também vinculada à Secretaria de Aviação Civil (SAC), a Empresa Brasileira de Infraestrutura Aeroportuária (INFRAERO) é uma empresa pública nacional fundada em 1973 sua função é administrar desde grandes até alguns aeroportos pequenos que ainda não recebem voos comerciais regulares. A empresa administra e investe em infraestrutura aeroportuária, com obras e melhorias em todos os estados brasileiros. Esta detém participação de 49\% nas Sociedades de Propósito Específico (SPE's) que administram os aeroportos de Guarulhos e Viracopos (SP), Brasília (DF), Confins (MG) e Galeão (RJ) além de ser a única empresa pública brasileira autorizada pela Agência Nacional de Aviação Civil (ANAC) a oferecer treinamentos especializados. (INFRAERO, 2015).

O outro órgão assessor direto da Presidência da República é o Ministério da Defesa e tem a função de coordenar as ações do Exército Marinha e Aeronáutica, no qual é assessorado pelo Comando da Aeronáutica.

Entre as várias funções do Comando da Aeronáutica destacam-se: formular o planejamento estratégico e executar ações relativas à defesa do país no campo aeroespacial, formular e conduzir a política aeronáutica nacional (civil e militar) e orientar, coordenar e controlar as atividades de aviação civil. (Decreto 3080, 1999).

Este tem como subordinado o DECEA que realiza as atividades de gerenciamento de tráfego, medições, ajuste e manutenção de pequenas infraestruturas. 


\subsection{Poder dos fornecedores}

Os principais insumos para indústria brasileira de transporte aéreo de passageiros são o querosene e as aeronaves. Pode-se considerar que os fornecedores de aeronaves e de querosene têm poder de negociação na indústria nacional de aviação civil porque são os principais produtos necessários para a realização das operações. A Petrobrás por meio da sua empresa distribuidora BR é a líder na distribuição de querosene de aviação no Brasil havendo apenas os grupos Raízen e AIR BP como concorrentes, estas detiveram parcelas de mercado em 2013 equivalentes a 59,57\%,33,79\% e 6,64\% respectivamente.

Essa estrutura oligopolista favorece as empresas fornecedoras de querosene no Brasil que detêm forte poder de negociação uma vez que a quantidade de ofertantes é pequena, é possível observar na Figura 12 que, o impacto do poder dos ofertantes de combustível de aviação se traduz em custos elevados.

Figura 12- Estrutura de custos da indústria brasileira de transporte aéreo de passageiros.

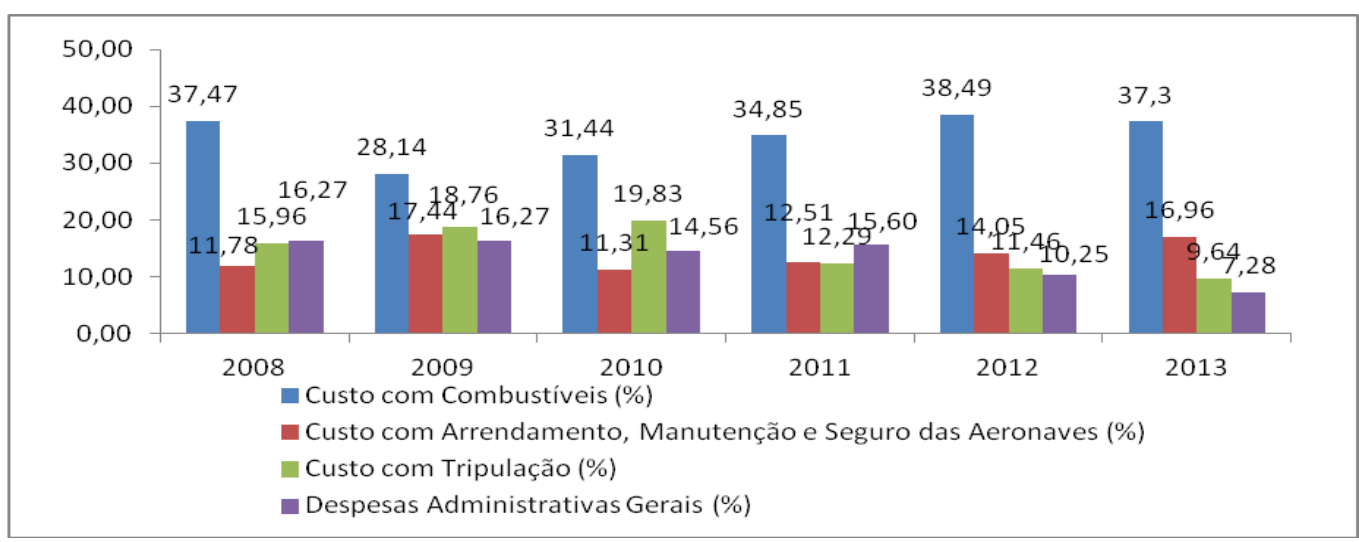

Fonte: ANAC (2013).

O custo com querosene juntamente com os custos com arrendamentos de aeronaves, tripulação e despesas administrativas gerais significaram em média 76,61 \% dos custos totais durante o período analisado. Cabe ressaltar que o custo com tripulação é o segundo e as despesas administrativas gerais são o terceiro maior item de custo, indícios de que há um elevado nível de custos fixos na indústria.

Os fornecedores de aeronaves têm menos poder de negociação do que os fornecedores de querosene devido à maior quantidade de fornecedores, no entanto, o poder de negociação dos fornecedores é bastante relevante uma vez que há apenas oito fabricantes mundiais de aeronaves de médio e grande porte, como a, Boeing, Airbus, Embraer, ATR, Fokker, LET, Cessna e McDonnel Douglas. O Quadro 4 mostra a quantidade de aeronaves em funcionamento na indústria brasileira por fabricante. 
Quadro 4: Quantitativo de aeronaves no Brasil

\begin{tabular}{|r|r|r|r|r|r|}
\hline Empresa & 2009 & 2010 & 2011 & 2012 & 2013 \\
\hline Boeing & 177 & 176 & 180 & 187 & 210 \\
\hline Airbus & 125 & 145 & 166 & 165 & 183 \\
\hline Embraer & 49 & 67 & 56 & 75 & 82 \\
\hline ATR & 30 & 45 & 45 & 67 & 71 \\
\hline Fokker & 14 & 14 & 14 & 14 & 12 \\
\hline LET & 10 & 12 & 11 & 5 & 5 \\
\hline Cessna & 7 & 7 & 6 & 5 & 0 \\
\hline McD. Douglas & 4 & 3 & 2 & 0 & 0 \\
\hline Total & 416 & 469 & 480 & 518 & 563 \\
\hline
\end{tabular}

Fonte: ANAC (2013).

Segundo a ANAC (2013), houve um crescimento anual de 7,33\% nos custos com arrendamentos na indústria brasileira de transporte aéreo de passageiros nos últimos três anos, encerrando o último ano com um custo de 5,3 bilhões de reais. O Quadro 5 mostra que os preços das aeronaves são bastante elevados.

Quadro 5 : Preços de aeronaves para transporte de passageiros

\begin{tabular}{|r|r|r|r|r|}
\cline { 2 - 5 } \multicolumn{1}{c|}{} & Modelo básico & $\begin{array}{r}\text { Preço US\$ } \\
\text { (Milhões) }\end{array}$ & Modelo luxuoso & Preço US\$ (Milhões) \\
\hline AIRBUS & A318 & 71,9 & A380 & 414,4 \\
\hline BOEING & 737600 & 57,0 & $78710 \mathrm{X}$ & 275,0 \\
\hline ATR & $42-500$ & 12,1 & $72-600$ & 19,0 \\
\hline CESSNA & GRAND & & GRAND & 1,8 \\
\hline EMBRAER & CARAVAN & 1,8 & CARAVAN & 40,0 \\
\hline
\end{tabular}

Fonte: Airbus (2014) e Aircraft Compare.com (2014).

As principais fornecedoras de aeronaves para a indústria brasileira são a Airbus, Boeing, ATR e Embraer que detém juntas 96,98\% do mercado brasileiro de fornecimento de aeronaves.

No entanto, cabe ressaltar que por ordem de grandeza, o principal vilão do preço do combustível é o montante de impostos incidentes. Segundo o Instituto Brasileiro de Tributação (2014), o montante de impostos sobre este componente é de 46,72\% do seu preço final, alíquota superior à praticada no valor do diesel usado em ônibus de transporte intermunicipal e interestadual, que é de 40,50\%.

Como um dos fatores que contribuem para essa expressiva participação é o percentual de ICMS, há uma grande divergência de alíquotas entre os diversos estados brasileiros. Segundo a Fiscontex (2015) há uma grande diferença nas alíquotas de ICMS praticada entre os vários estados brasileiros, entre os principais destacam: São Paulo (25\%), Rio de Janeiro (20\%) e Santa Catarina (12\%).

Pode-se afirmar que o poder de negociação dos fornecedores é forte porque os principais itens de fornecimento provêm de indústrias altamente concentradas que conseguem ditar preços elevados. 


\subsection{Poder dos compradores}

Segundo Oliveira (2009), com a atual dinâmica de quase desregulamentação o número de passageiros no mercado doméstico brasileiro tem experimentado taxas de crescimento superiores ao dobro da taxa de crescimento da renda nacional. A mudança na elasticidade renda da demanda do setor sugere a existência de outros fatores que também contribuíram para o crescimento setorial. Dentre estes fatores pode-se mencionar a melhoria na distribuição de renda da população e a redução dos preços do setor, tornando o transporte aéreo acessível a um público consumidor antes afastado deste serviço.

A ANAC (2013) mostra que no Brasil são realizadas 25,45 decolagens para cada mil reais de PIB, isso pode ser observado pela evolução dos seus quantitativos. No período 2008-2013 houve um aumento equivalente a $45,59 \%$ no número de voos domésticos, percentual superior ao número de voos internacionais, $33,11 \%$.

A Figura 13 ilustra a evolução da oferta e alguns indicadores de desempenho e qualidade do serviço ofertado.

Figura 13: Expansão das operações

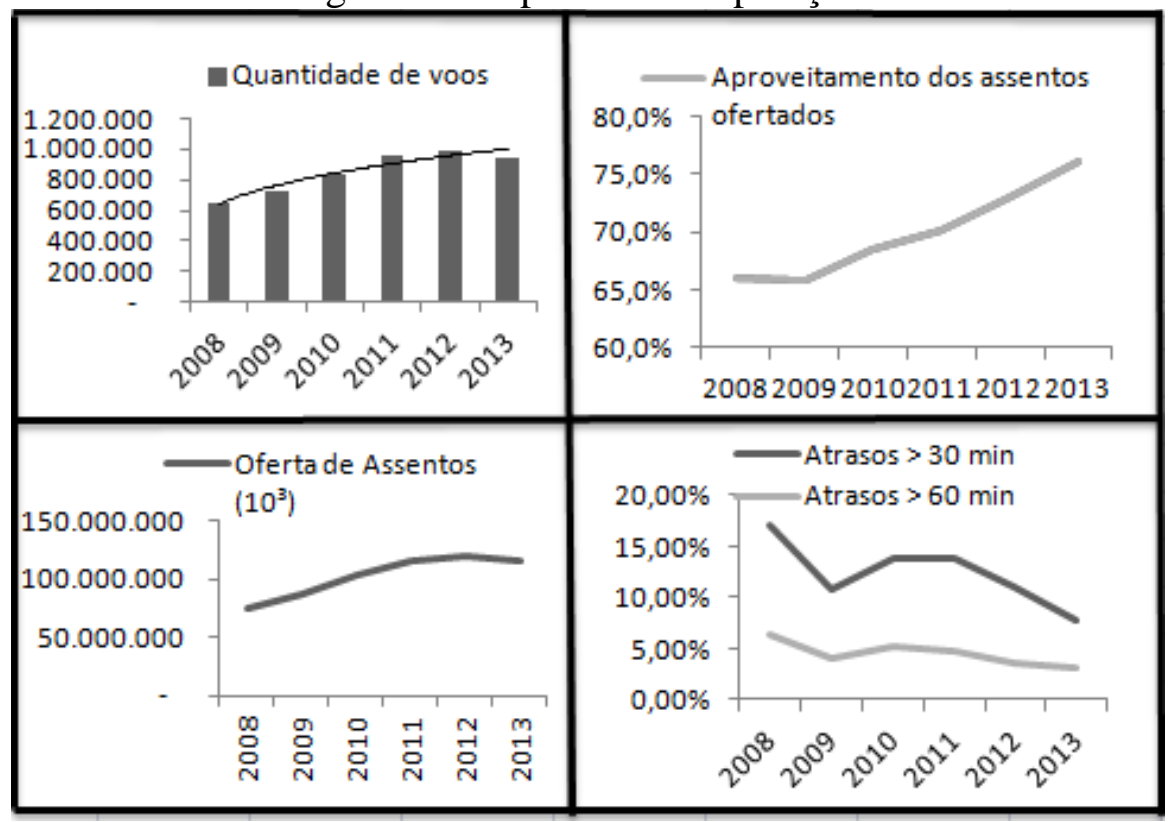

Fonte: ANAC (2013).

Com o aumento da oferta é possível perceber uma melhora no aproveitamento da oferta em termos de RPK/ASK equivalente a 10,20\%, além disso, a qualidade do serviço prestado aumentou havendo uma redução de $9,09 \%$ nos atrasos com um tempo acima de 30 minutos e $3,04 \%$ nos atrasos com um tempo acima de 60 minutos.

A capacidade instalada média da indústria brasileira de aviação civil em unidades ASK no período 2008-2013 é de 102,62 bilhões por ano. Durante o mesmo período, a média de passageiros transportados em unidades RPK foi de 72,26 bilhões; uma quantidade bem aquém da capacidade instalada. Os compradores apresentam algum poder de negociação uma vez que a oferta é bem maior do que demanda. 
Ressalta-se que no ano de 2012 houve duas grandes fusões, a Azul realizou uma fusão com a TRIP e a companhia GOL linhas aéreas inteligentes incorporou a Webjet. Esse movimento no mercado gerou uma influencia direta nas características dos produtos da indústria.

A Webjet era única companhia aérea que adotava uma política de baixos custos e pressionava as outras companhias com a oferta de preços bastante competitivos. Os principais elementos que compunham a política de baixos custos eram: não oferta de alimentação a bordo, falta de investimento em atualização da frota e a exclusão de lojas físicas para venda de passagens.

Os produtos e serviços na indústria brasileira de aviação civil ficaram menos diferenciados após as fusões, principalmente por conta da incorporação da Webjet realizada pela companhia GOL, conforme a Figura 14.

Figura 14: Características dos serviços das companhias aéreas brasileiras
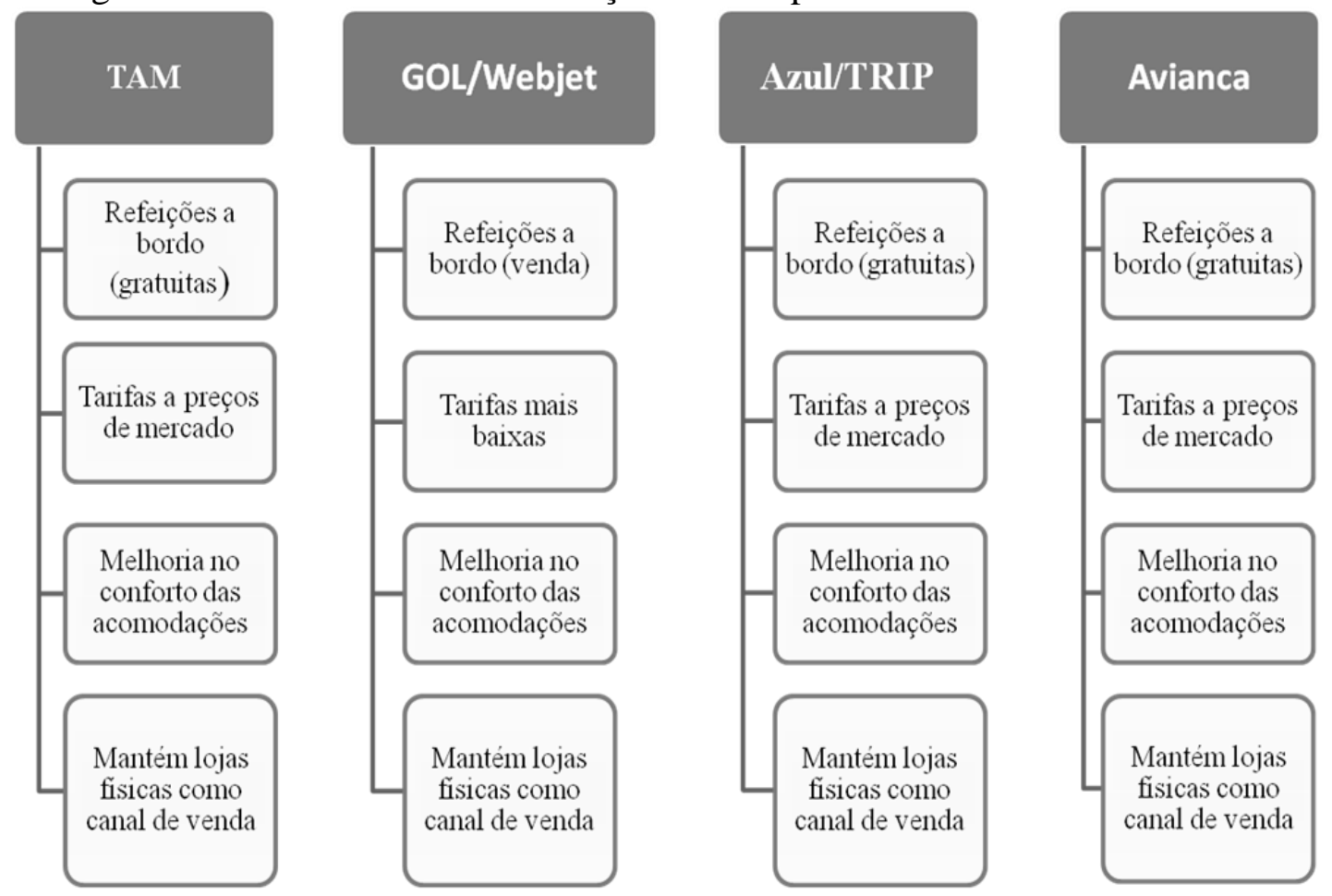

A padronização dos produtos e serviços restringiu as possibilidades de escolha dos compradores, porém este efeito foi benéfico uma vez que estes passaram a poder de optar entre contratar os serviços de uma companhia ou de outra, sem arcar com custos de diferenciação significativos. O efeito é a ocorrência de disputas de preços que pode ser observado na evolução da tarifa média de transporte aéreo praticada no Brasil de acordo com a Figura 15. 
Figura 15 - Evolução da tarifa média no Brasil.

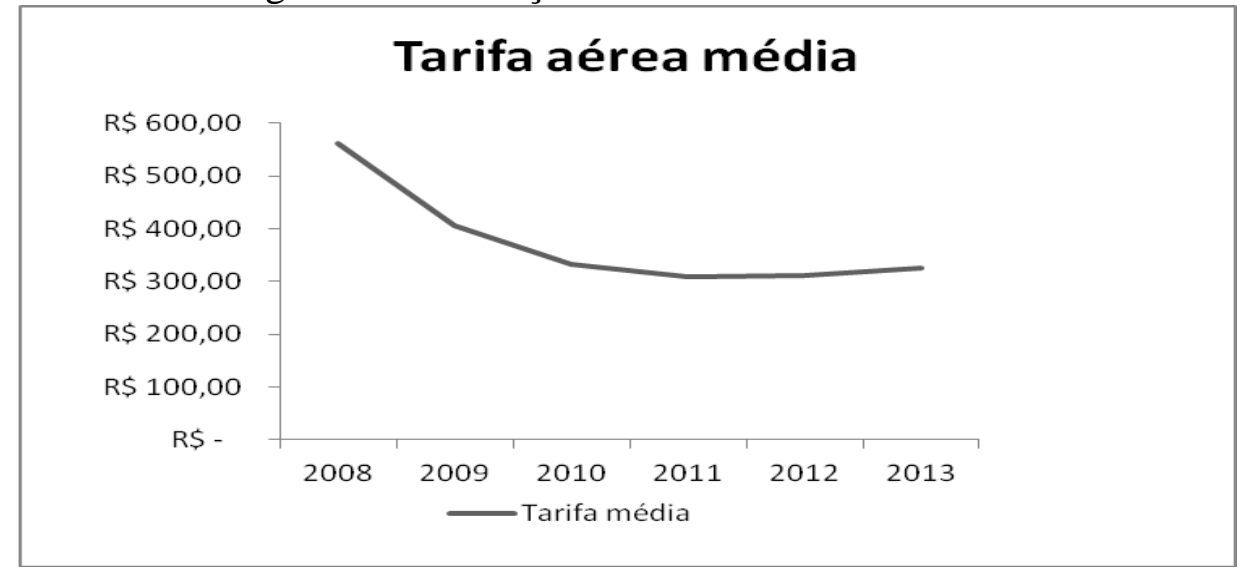

Fonte: ANAC (2013).

Ao longo do período houve uma brusca redução do valor médio da tarifa de transporte aéreo de passageiros no Brasil, aproximadamente 58,00 \% de redução no valor de 2013 em relação a 2008. Cabe ressaltar que o declínio da tarifa média do transporte aéreo não é um reflexo da competição, essa redução também está relacionada à estratégia de ganhos em escala de operação.

A realização da compra dos bilhetes de passagens aérea com antecedência é uma estratégia que o consumidor vem adotando para comprar tarifas mais baixas, conforme Quadro 6. 
Quadro 6: Percentual de compras de bilhetes por intervalo de tarifa aérea real.

\begin{tabular}{|c|c|c|c|c|c|c|c|c|c|c|c|c|}
\hline $\begin{array}{r}\text { Intervalo de Tarifa Aérea } \\
\text { Doméstica Real }\end{array}$ & 2002 & 2003 & 2004 & 2005 & 2006 & 2007 & 2008 & 2009 & 2010 & 2011 & 2012 & 2013 \\
\hline$>0,00$ e $<100,00$ & $0,03 \%$ & $0,12 \%$ & $1,09 \%$ & $0,26 \%$ & $4,37 \%$ & $3,24 \%$ & $0,35 \%$ & $1,36 \%$ & $5,16 \%$ & $12,84 \%$ & $11,69 \%$ & $9,81 \%$ \\
\hline$>=100,00$ e $<200,00$ & $4,05 \%$ & $2,76 \%$ & $3,49 \%$ & $5,66 \%$ & $7,64 \%$ & $14,84 \%$ & $4,27 \%$ & $15,05 \%$ & $24,54 \%$ & $27,48 \%$ & $29,40 \%$ & $29,58 \%$ \\
\hline$>=200,00$ e $<300,00$ & $15,55 \%$ & $12,54 \%$ & $9,78 \%$ & $10,24 \%$ & $13,08 \%$ & $22,38 \%$ & $14,18 \%$ & $23,96 \%$ & $22,17 \%$ & $19,23 \%$ & $21,38 \%$ & $19,50 \%$ \\
\hline$>=300,00$ e $<400,00$ & $19,04 \%$ & $13,53 \%$ & $11,87 \%$ & $16,02 \%$ & $14,08 \%$ & $20,66 \%$ & $15,55 \%$ & $17,04 \%$ & $17,66 \%$ & $14,07 \%$ & $12,98 \%$ & $13,77 \%$ \\
\hline$>=400,00$ e $<500,00$ & $17,67 \%$ & $14,22 \%$ & $12,00 \%$ & $11,47 \%$ & $13,64 \%$ & $14,63 \%$ & $16,39 \%$ & $14,13 \%$ & $14,06 \%$ & $9,89 \%$ & $8,15 \%$ & $8,97 \%$ \\
\hline$>=500,00$ e $<600,00$ & $14,15 \%$ & $22,27 \%$ & $18,98 \%$ & $18,70 \%$ & $13,35 \%$ & $7,63 \%$ & $14,11 \%$ & $11,96 \%$ & $7,65 \%$ & $6,03 \%$ & $5,24 \%$ & $5,95 \%$ \\
\hline$>=600,00$ e $<700,00$ & $8,50 \%$ & $5,42 \%$ & $9,27 \%$ & $9,10 \%$ & $9,07 \%$ & $4,61 \%$ & $11,55 \%$ & $7,35 \%$ & $3,43 \%$ & $3,64 \%$ & $3,52 \%$ & $3,93 \%$ \\
\hline$>=700,00$ e $<800,00$ & $5,14 \%$ & $9,54 \%$ & $9,50 \%$ & $6,82 \%$ & $5,50 \%$ & $3,29 \%$ & $5,73 \%$ & $3,38 \%$ & $2,22 \%$ & $2,47 \%$ & $2,36 \%$ & $2,66 \%$ \\
\hline$>=800,00$ e $<900,00$ & $4,28 \%$ & $6,08 \%$ & $8,26 \%$ & $6,44 \%$ & $5,09 \%$ & $2,66 \%$ & $5,19 \%$ & $2,13 \%$ & $1,41 \%$ & $1,61 \%$ & $1,64 \%$ & $1,82 \%$ \\
\hline$>=900,00 \mathrm{e}<1.000,00$ & $2,45 \%$ & $2,79 \%$ & $3,82 \%$ & $3,95 \%$ & $3,43 \%$ & $2,44 \%$ & $3,42 \%$ & $1,25 \%$ & $0,73 \%$ & $1,03 \%$ & $1,15 \%$ & $1,23 \%$ \\
\hline$>=1.000,00 \mathrm{e}<1.100,00$ & $2,62 \%$ & $2,60 \%$ & $2,74 \%$ & $2,54 \%$ & $2,70 \%$ & $1,08 \%$ & $3,34 \%$ & $0,83 \%$ & $0,41 \%$ & $0,61 \%$ & $0,78 \%$ & $0,77 \%$ \\
\hline$>=1.100,00 \mathrm{e}<1.200,00$ & $1,69 \%$ & $1,39 \%$ & $1,58 \%$ & $1,57 \%$ & $1,75 \%$ & $0,55 \%$ & $1,52 \%$ & $0,44 \%$ & $0,21 \%$ & $0,36 \%$ & $0,49 \%$ & $0,53 \%$ \\
\hline$>=1.200,00$ e $<1.300,00$ & $1,31 \%$ & $1,24 \%$ & $1,72 \%$ & $1,46 \%$ & $1,02 \%$ & $0,50 \%$ & $0,89 \%$ & $0,33 \%$ & $0,11 \%$ & $0,22 \%$ & $0,33 \%$ & $0,39 \%$ \\
\hline$>=1.300,00 \mathrm{e}<1.400,00$ & $0,87 \%$ & $1,11 \%$ & $1,58 \%$ & $1,58 \%$ & $0,91 \%$ & $0,23 \%$ & $1,03 \%$ & $0,11 \%$ & $0,09 \%$ & $0,16 \%$ & $0,25 \%$ & $0,40 \%$ \\
\hline$>=1.400,00$ e $<1.500,00$ & $0,82 \%$ & $1,54 \%$ & $0,98 \%$ & $0,73 \%$ & $1,12 \%$ & $0,18 \%$ & $0,62 \%$ & $0,13 \%$ & $0,06 \%$ & $0,11 \%$ & $0,17 \%$ & $0,18 \%$ \\
\hline$>=1.500,00$ & $1,84 \%$ & $2,85 \%$ & $3,34 \%$ & $3,46 \%$ & $3,26 \%$ & $1,09 \%$ & $1,87 \%$ & $0,55 \%$ & $0,11 \%$ & $0,25 \%$ & $0,48 \%$ & $0,50 \%$ \\
\hline Soma das cinco faixas & $75 \%$ & $72 \%$ & $62 \%$ & $66 \%$ & $63 \%$ & $80 \%$ & $72 \%$ & $82 \%$ & $86 \%$ & $84 \%$ & $84 \%$ & $82 \%$ \\
\hline
\end{tabular}

Fonte: ANAC (2013). 
O Quadro 6, apresenta os dados de percentual de compras de bilhetes por intervalo de tarifa aérea real. Para ter uma melhor visualização da evolução da capacidade do consumidor em acessar preços mais baixos foram marcados em cor cinza os cinco maiores percentuais em cada ano.

É possível observar que os maiores percentuais e compra de bilhetes de passagens aéreas vai migrando para faixas de preços menores ao longo do tempo. Para fins de ilustração, observase que $72 \%$ e $62 \%$ das compras nos anos 2003-2004 se concentraram nos intervalos de preço $>=200,00$ e $<300,00$ e $>=700,00$ e $<800,00$. Nos anos 2011-2013 84\% e $82 \%$ do total de compras se concentraram nos intervalos de preço $>0,00$ e $<100,00$ e $>=400,00$ e $<500,00$. Vale ressaltar a programação das compras não é o único fator que explica essas diminuições de preço, há também a influência das tarifas promocionais.

\subsection{Ameaça de entrada}

Existem quatro principais barreiras à entrada na indústria aérea brasileira. A primeira barreira é representada pela autorização para operar que é concedida pela ANAC. A segunda barreira é a exigência de dinheiro (a) para empregar na compra ou aluguel de aeronaves e (b) para giro, para a compra de querosene, por exemplo. A terceira é a ocorrência de economias de escala. A quarta é o acesso aos canais de distribuição, Gates e Slots nos principais aeroportos.

A ocorrência de um novo entrante no mercado de transporte aéreo de passageiros é pouco recorrente, pois se trata de um mercado que exige elevado potencial de investimento.

Os itens de custo mais relevantes para um entrante no mercado são o valor das aeronaves que podem ser adquiridas por meio de compra à vista ou por contrato de leasing, a utilização de aeroportos e o capital de giro necessário para arcar com os custos iniciais de operação. Por se tratar de uma indústria que requer elevados investimentos em tecnologia e aportes de capital para manter a operação, há uma necessidade natural por parte das empresas de obter economias de escala.

Há elevadas barreiras de entrada levantadas pelas companhias aéreas brasileiras, uma delas é o nível de ativo imobilizado que atualmente aproxima-se de quatorze bilhões de reais.

Figura 16: Ativo imobilizado total.

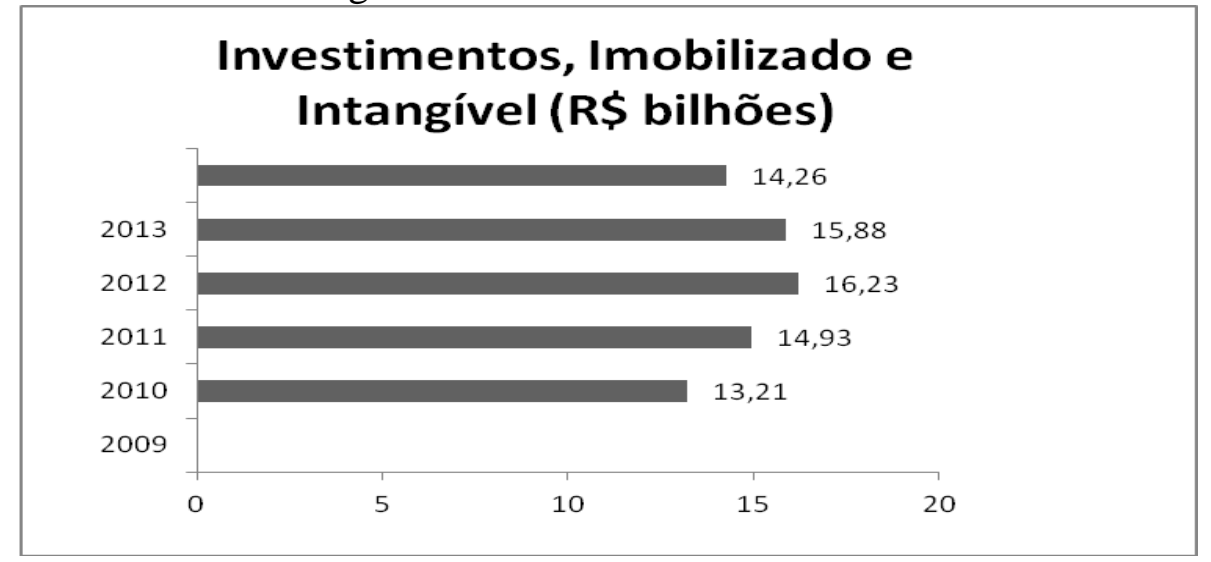

Fonte: ANAC (2013).

Todo capital empregado em ativos imobilizados está diretamente relacionado a elevados níveis de excesso de oferta de Assentos Quilômetros Ofertados- ASK. 
No entanto, a indústria vem melhorando consideravelmente a utilização dos seus ativos imobilizados. O Quadro 7 mostra a evolução do indicador de Giro do Ativo Imobilizado GAI. Este reflete a eficiência da utilização de seus ativos fixos em termos de captação de receita.

Quadro 7 : Giro do Ativo Imobilizado

\begin{tabular}{|r|r|r|r|r|r|}
\hline 2008 & 2009 & 2010 & 2011 & 2012 & 2013 \\
\hline 1,13 & 1,28 & 1,43 & 1,53 & 1,69 & 2,19 \\
\hline
\end{tabular}

Fonte: Elaborado com base em dados da ANAC (2013).

É possível notar uma evolução neste indicador, que indica quantas unidades de faturamento a indústria consegue para cada unidade monetária empregada no ativo imobilizado. Ou seja, no último ano o transporte aéreo brasileiro conseguiu captar $R \$ 2,19$ para cada $R \$ 1,00$ empregado em ativos fixos.

No entanto, os resultados operacionais líquidos negativos são fatores recorrentes historicamente. Durante o período 2008-2013 houve quatro resultados negativos anuais, conforme o Quadro 8.

Quadro 8: Resultados líquidos da indústria de transporte de passageiros em $\mathrm{R} \$ 10^{3}$.

\begin{tabular}{|c|c|c|c|c|c|}
\hline \multicolumn{6}{|c|}{ RESULTADOS OPERACIONAIS LÍQUIDOS DA INDÚSTRIA } \\
\hline 2008 & 2009 & 2010 & 2011 & 2012 & 2013 \\
\hline & & & & & \\
$-3.254 .773,61$ & $1.542 .917,13$ & $718.031,17$ & $-1.592 .910,95$ & $-3.463 .830,70$ & $-2.400 .622,00$ \\
\hline
\end{tabular}

Fonte: ANAC (2013).

Isso se dá porque os custos são bastante elevados e em vários períodos é possível perceber que estes superam o valor total das receitas de voo. Uma das características econômicas da indústria é a ocorrência de economias decrescentes de escala, isso ocorre quando o custo unitário denominado CASK cresce em função do aumento das unidades ofertadas ASK, conforme a Figura 17.

Figura 17: Análise da economia de escala da indústria brasileira de transporte aéreo de passageiros

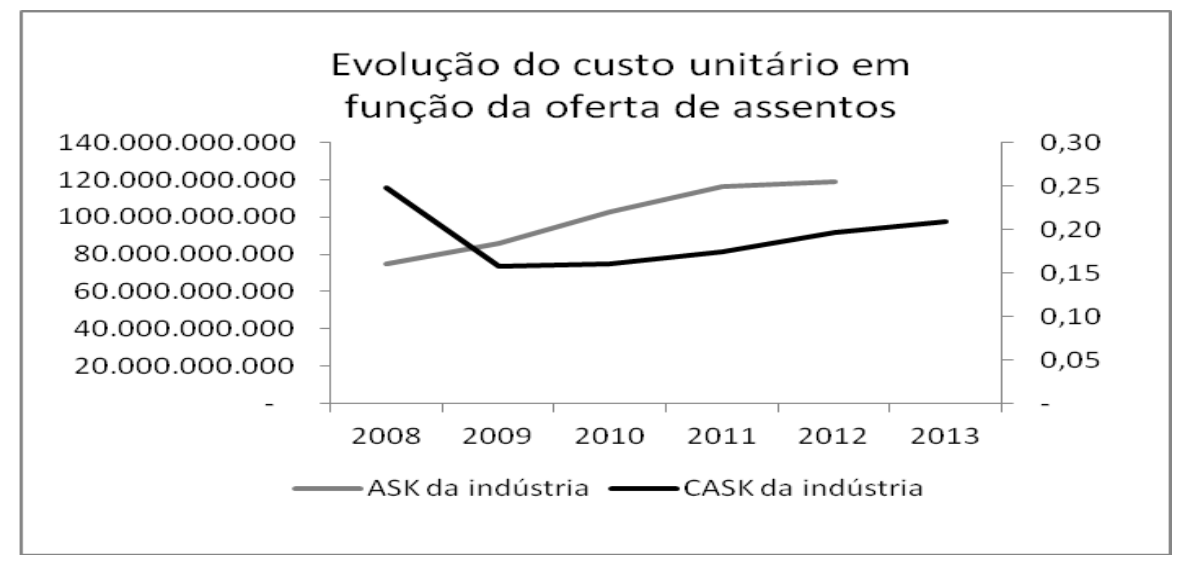

Fonte: ANAC (2013). 
A Figura 17 mostra que o custo unitário CASK da indústria acompanha o crescimento da oferta de assentos ASK. Mesmo havendo retornos decrescentes é possível notar que a indústria tem uma evolução da quantidade de assentos ofertados, o que mostra uma forte busca por economias de escala.

A concorrência entre as companhias aéreas para operar nos principais aeroportos do país é acentuada. Segundo ANAC (2013), há no Brasil 147 aeroportos sendo utilizados para voos domésticos regulares e não regulares. Os quatro principais são: o Aeroporto de Guarulhos, Aeroporto de Congonhas, Aeroporto de Brasília e o Aeroporto Internacional de Viracopos/ Campinas. A Figura 18 mostra a quantidade utilizada de aeroportos por cada uma das companhias aéreas brasileiras no ano de 2013.

Figura 18 - Quantidade de aeroportos utilizados pelas principais companhias aéreas.
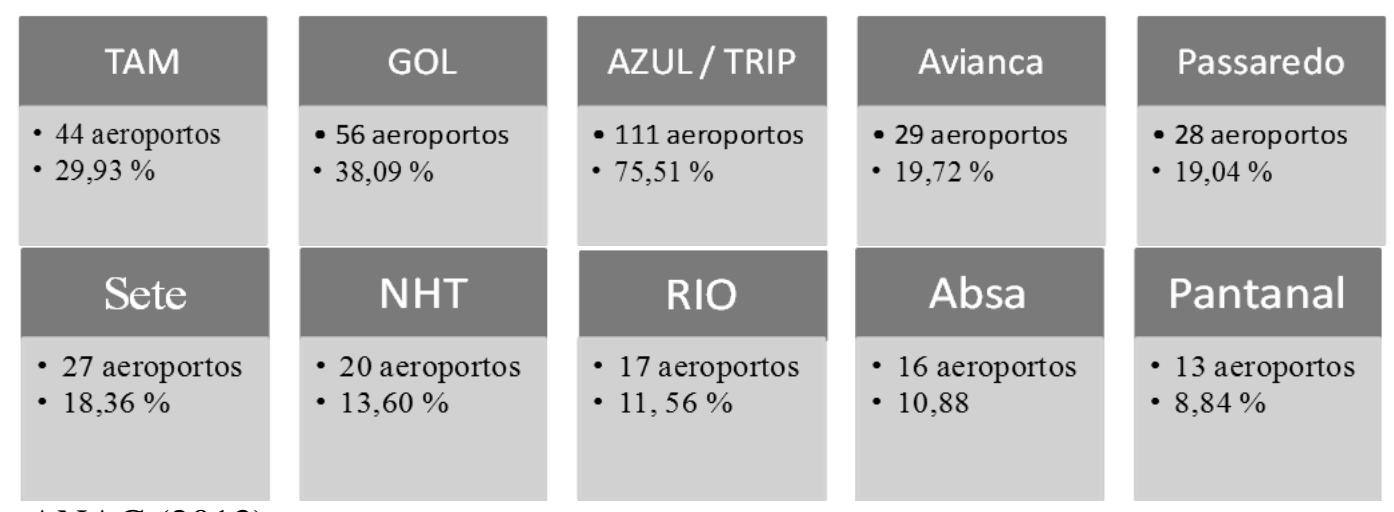

Fonte: ANAC (2013).

Os quantitativos mostram o elevado interesse na utilização dos aeroportos por parte das companhias aéreas atuantes na indústria. Esse fato dificulta o acesso a canais de distribuição aos entrantes.

\subsection{Produtos substitutos}

Um dos principais exemplos de efeito substituição no transporte aéreo ocorre na União Europeia. Há competição entre as companhias aéreas e o transporte ferroviário de passageiros.

O estudo da ERA (2016) apresenta uma análise comparativa entre estes dois modos de transporte. Sendo que o transporte vem se apresentando como o substituto no transporte rodoviário de passageiros. Segundo a ERA (2016), a Europa no transporte aéreo como o principal instrumento de mobilidade nos últimos 15 anos sendo o responsável por cerca de 75 milhões de passageiros por ano.

Para avaliar esses efeitos, D’Alfonso, Jiang e Bracaglia (2014) utilizou um modelo de concorrência. Com base na função utilidade do consumidor, para avaliou a preferência dos passageiros em relação ao transporte aéreo e o ferroviário de alta velocidade. Os fatores incluídos na Proxy são o preço dos bilhetes, o tempo de acesso, o tempo de viagem, o atraso da viagem em relação ao previsto no cronograma de transporte. Os resultados indicaram que os serviços aéreos resultam em menor tempo de viagem, no entanto, os passageiros precisam gastar mais tempo de acesso/saída para o voo em decorrência da localização dos aeroportos.

No Brasil, o transporte rodoviário pode competir com o aéreo em trechos curtos, como Rio São Paulo. $\mathrm{O}$ país não dispõe de transporte ferroviário de alta velocidade para passageiros. $\mathrm{O}$ 
principal modo de transporte adotado pelo Brasil foi o rodoviário, tanto para cargas quanto para pessoas.

O transporte aéreo tem uma importante cooperação com as agências de viagens, pode dizer que ambas são complementares.

As agências de viagens estão divididas em duas modalidades, viagens de turismo e viagens corporativas. No seguimento de turismo, há a venda de passagens aéreas e de passeio marítimo, no seguimento de viagens corporativas há predominância de vendas de passagens aéreas.

Nesta cooperação, há benefícios para ambas companhias aéreas. As agências de viagens impulsionam as vendas de passagens aéreas por meio de sua publicidade e pacotes turísticos que incluem estadia e traslado. Anteriormente, as companhias aéreas pagavam uma comissão equivalente a $10 \%$ do valor total dos bilhetes vendidos, este acordo foi alterado em $2012 \mathrm{e}$ hoje não há pagamento de comissões às agências de turismo.

O seguimento de viagens corporativas é relativamente pequeno se comparado ao de viagens turísticas, no entanto, apresenta uma boa articulação entre os agentes do seguimento por meio de uma associação.

A Associação Brasileira de Agências de Viagens Corporativas (Abracorp) apresenta relatório detalhado do segmento de viagens corporativas no Brasil referente aos anos 2012 e 2013, este é reflexo de informações consolidadas de trinta e duas agências de viagens associadas. A Figura 19 abaixo ilustra o desempenho obtido pelo conjunto de empresas associadas em termos de vendas.

Figura 19: Vendas corporativas.

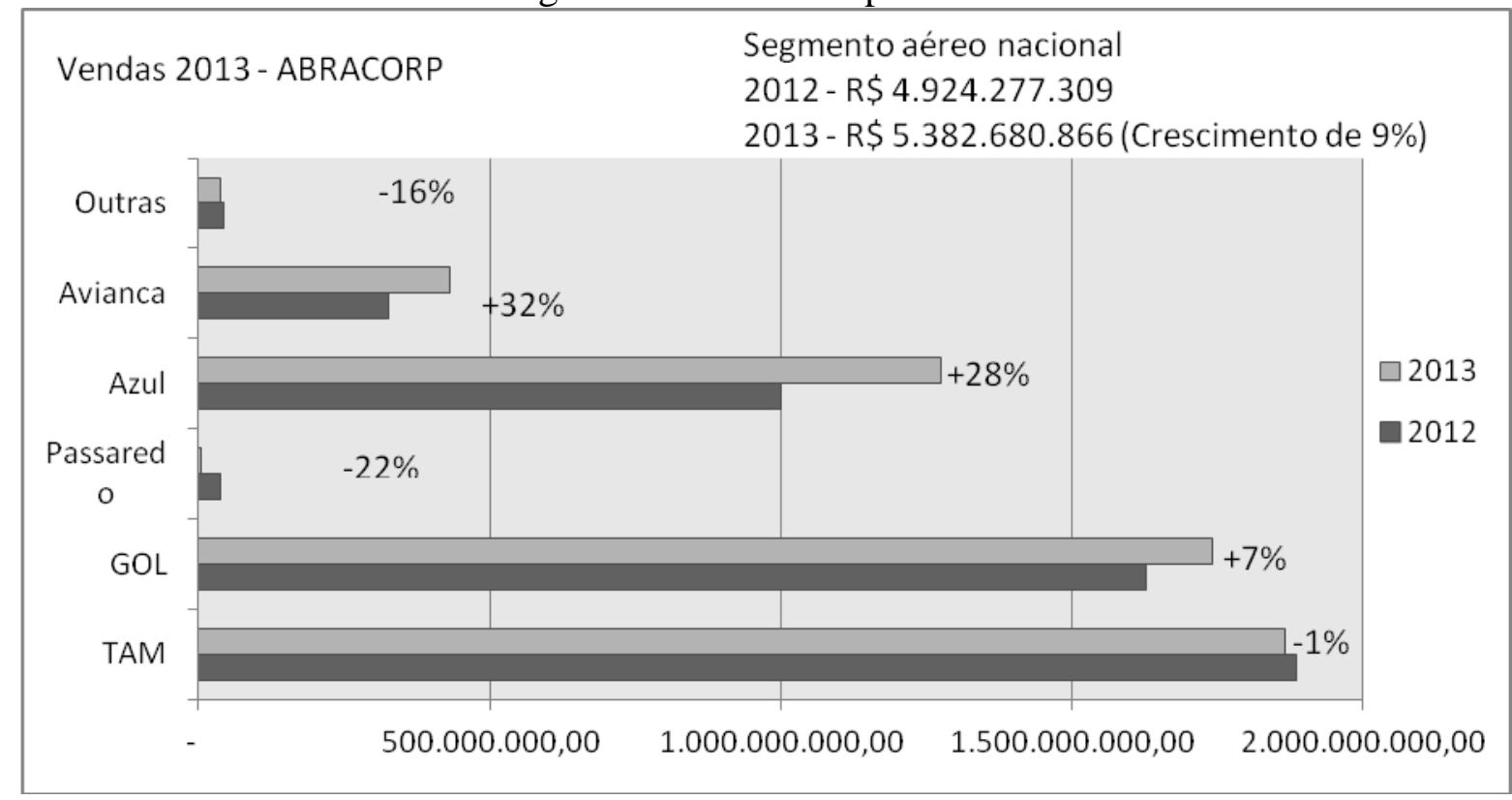

Fonte: Associação Brasileira de Agências de Viagens Corporativas (2014).

Os valores totais aproximados foram obtidos pelo produto das quantidades de bilhetes emitidos por companhias aéreas e a sua respectiva tarifa média. 
Quadro 9: Quantidade de bilhetes vendidos/ tarifas médias

\begin{tabular}{|r|r|r|r|}
\hline Empresa & Qtd bilhetes & Valor (2013) & Tarifa Média \\
\hline AVIANCA & 928.542 & 430.959 .223 & 464 \\
\hline Azul & 2.394 .590 & 1.275 .775 .106 & 533 \\
\hline GOL & 3.168 .400 & 1.742 .521 .881 & 550 \\
\hline Passaredo & 85.840 & 29.917 .167 & 349 \\
\hline TAM & 3.137 .836 & 1.866 .772 .540 & 192 \\
\hline Demais & 9.906 .641 & 5.382 .680 .866 & 543 \\
\hline
\end{tabular}

Fonte: Elaborado a partir de ABRACORP (2014).

É possível notar que as principais beneficiadas durante o ano de 2013 foram as companhias GOL, TAM, Azul e Avianca, as quatro maiores companhias da indústria.

O reflexo desse resultado para a indústria brasileira de transporte aéreo de passageiros pode ser medido em unidades monetárias conforme o quadro 10 abaixo.

Quadro 10: Vendas de passagens corporativas em R\$

\begin{tabular}{|r|}
\hline $\begin{array}{r}\text { Vendas da } \\
\text { ABRACORP } \\
\left(\mathrm{R} \$ 10^{3}\right)\end{array}$ \\
\hline $5.382 .680,86$ \\
\hline
\end{tabular}

Fonte: Elaborado a partir de ABRACORP (2014).

Há uma boa articulação entre as agências de viagens corporativas por se tratar de um seguimento que detém uma pequena participação no mercado, fato que não ocorre no seguimento de viagens de turismo.

A competição entre as agências de viagens de turismo é intensa. A empresa mais rentável em 2013 foi a "Decolar" com o lucro líquido de R\$ 5,5 bilhões, seguida pela "CVC" com lucro líquido de R $\$ 4,45$ bilhões, a primeira de capital fechado e a segunda de capital aberto.

Por se tratar de uma agência que detém capital aberto tomaremos a empresa CVC para demonstrar o potencial de influência das agências de viagens turísticas na indústria brasileira de transporte aéreo de passageiros.

Quadro 11: Vendas de bilhetes

\begin{tabular}{|r|r|}
\hline Reservas Embarcadas & Vendas da ABRACORP \\
$\mathrm{CVC}$ & $\left(\mathrm{R} \$ 10^{3}\right)$ \\
$\left(\mathrm{R} \$ 10^{3}\right)$ & $5.382 .680,86$ \\
\hline $4.070 .400,00$ & \\
\hline
\end{tabular}

Fonte: Elaborado a partir de CVC (2014).

É possível notar que apenas a empresa CVC tem um poder de influência muito maior do que qualquer companhia de viagens corporativas, somente a empresa de voos turísticos CVC proporciona o faturamento equivalente a $75,62 \%$ do faturamento total das 32 agências de voo corporativo filiadas à Associação Brasileira de Agências de Viagens Corporativas (ABRACORP). Se comparado com o faturamento da indústria de transporte aéreo de Página 67 
passageiros em 2013, a CVC foi responsável por um percentual equivalente a 11,26\% do faturamento total de todas as companhias aéreas juntas.

Tais fatores aliados às estratégias de negócios das companhias aéreas vêm demonstrando uma sutil captura da demanda do transporte rodoviário de passageiros em trechos com extensão maior do que 75 quilômetros. A Figura 20 mostra a evolução da quantidade de passageiros transportados pelo modo rodoviário em comparação com o aéreo nos últimos dez anos.

Figura 20: Evolução da demanda de passageiros, aéreo versus rodoviário.

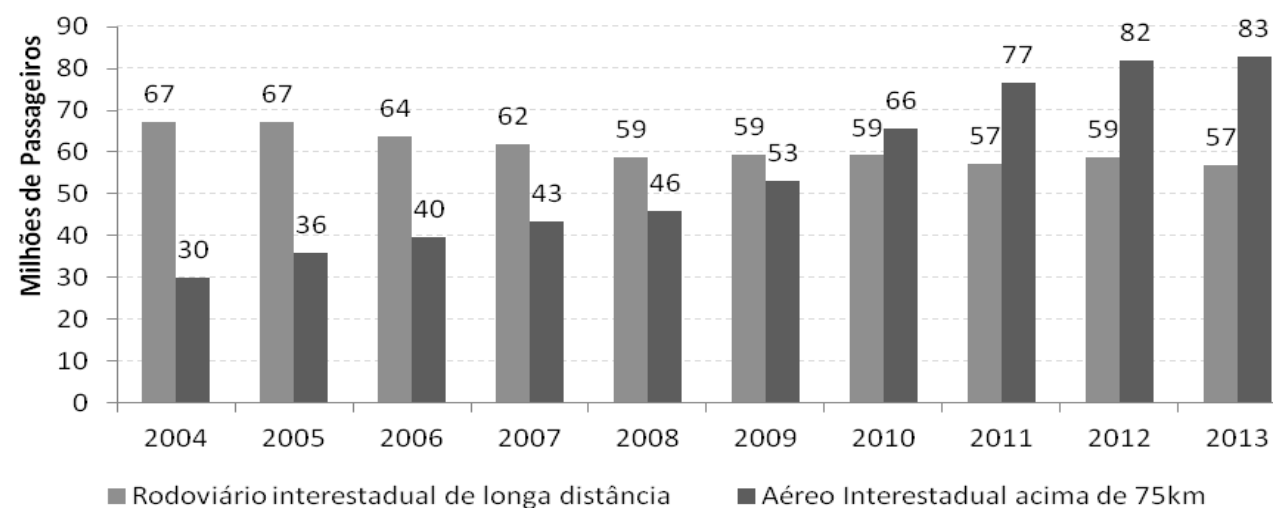

Fonte: ANAC (2013).

É possível notar que durante o período 2004-2013, houve uma evolução significativa da demanda de transporte aéreo em voos de longa distância $(176,66 \%)$ e uma importante diminuição da demanda do transporte rodoviário (14,92\%).

As respectivas parcelas de mercado apresentaram uma inversão de dominância, em 2004 o transporte rodoviário detinha $69,07 \%$ do total de passageiros enquanto o aéreo apenas 30,93\%. Essa situação se inverteu em 2013 quando o transporte aéreo passou a dominar $59,29 \%$ do total de passageiros em viagens de longa distância enquanto o rodoviário movimentou $40,71 \%$ dos passageiros.

A Figura 21 faz um comparativo entre a evolução das tarifas aéreas médias e a evolução do número de passageiros transportados no modo aéreo.

Figura 21: Efeito total na indústria de transporte aéreo de passageiros

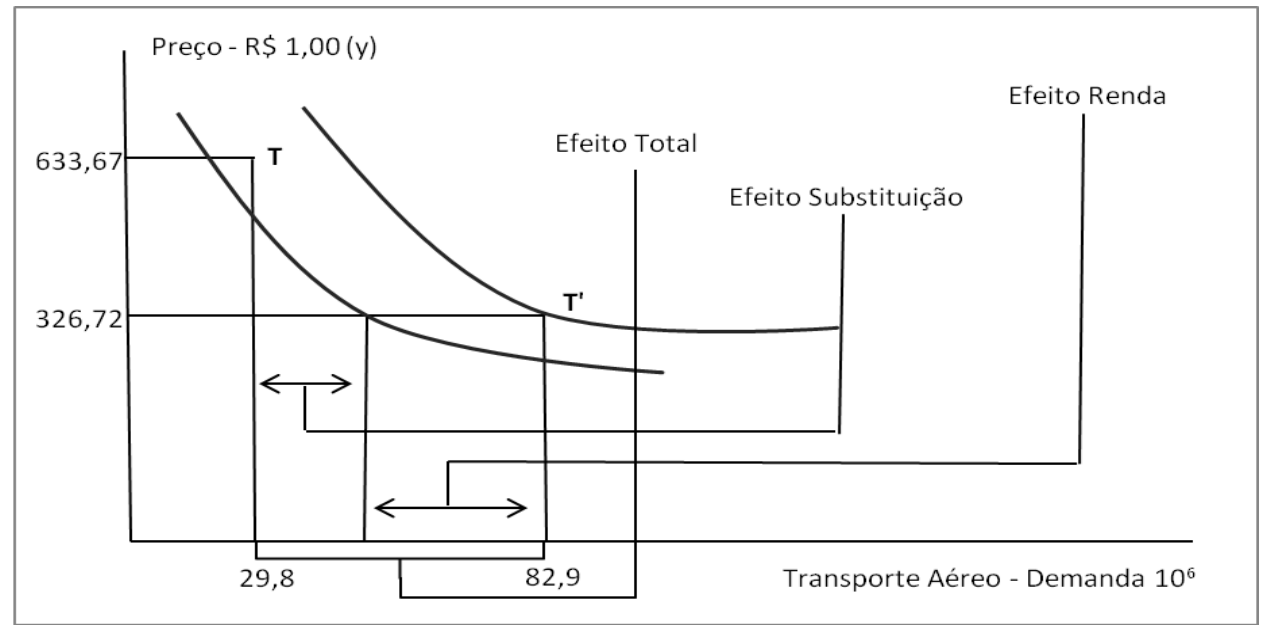


Fonte: Elaborado pelo autor com base em dados da ANAC (2013)

Ao comparar o instante T (ano de 2004) e o instante T' (ano de 2013) nota-se uma substancial redução no preço bem como o aumento na demanda. O efeito total gerado pela redução do preço médio é equivalente à diferença entre a demanda dos instantes $\mathrm{T}$ e $\mathrm{T}$ '. $\mathrm{O}$ efeito substituição é área do gráfico equivalente ao aumento de demanda do transporte aéreo respeitando a curva de indiferença que representa a restrição inicial.

A demanda do instante $T$ ' foi suficiente para deslocar a curva de indiferença para a direita, isso significa que para o consumidor passou a deter um maior poder de compra em decorrência da redução do preço médio. O efeito renda é área do gráfico que excede a área do efeito substituição.

O índice de elasticidades preço demanda é de 4,24, ou seja, durante o período o aumento da demanda foi equivalente a 4,24 vezes a redução da tarifa média. $O$ fato do índice de elasticidade ser maior do que 1 mostra que entre 2004 e 2013 o transporte aéreo foi um serviço elástico uma vez que houve uma significativa sensibilidade da sua demanda diante dos preços praticados.

\subsection{Concorrentes}

A indústria nacional de aviação civil é formada por duas empresas líderes, TAM e GOL, e por empresas seguidoras. Ocasionalmente, as duas líderes entram em rota de colisão e colocam em prática estratégias divergentes para aumentar as suas parcelas de mercado. Esta força é reputada como forte, os principais fatores estruturais que a caracterizam são o crescimento rápido da indústria, a capacidade aumentada em grandes incrementos e os grandes interesses estratégicos.

A indústria brasileira vem crescendo em ritmo acelerado em termos de oferta de assentos, onde a média de crescimento anual em termos de passageiros-quilômetros transportados pagos (RPK) e assentos-quilômetros ofertados (ASK) apresentam linhas de tendências similares à evolução do mercado internacional como mostra a Figura 22.

Figura 22: Evolução do RPK e do ASK

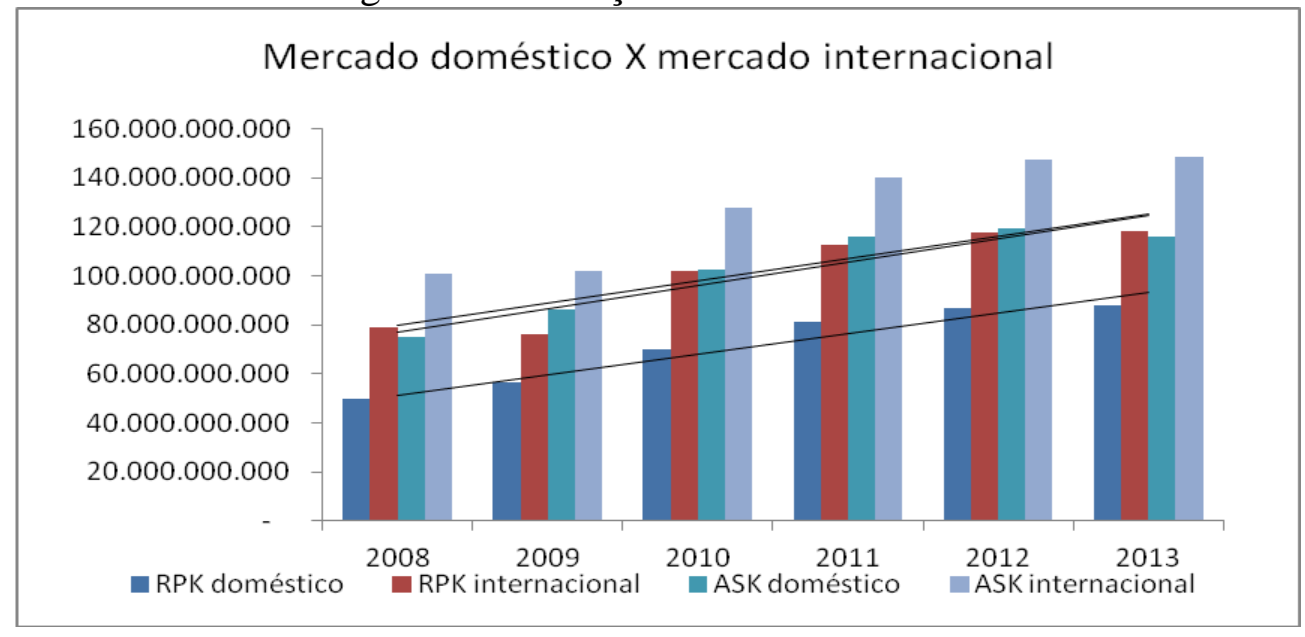

Fonte: ANAC (2013). 
No entanto, essa tendência não é um fator capaz medir o real crescimento em termos comparativos entre os dois mercados. É possível observar no gráfico que mesmo havendo linhas de tendências com inclinações similares há diferenças significativas em relação à magnitude dos valores.

Houve uma oferta de assentos maior em nível internacional do que doméstico; 7,49\% e 7,87\% respectivamente. Mesmo havendo um gradual aumento no percentual de aproveitamento dos assentos ofertados ainda há uma grande capacidade ociosa. O Quadro 12 expressa em números a diferença entre a oferta de assentos (ASK) e a quantidade de passageiros.

Quadro 12: Capacidade Ociosa do Transporte aéreo

\begin{tabular}{|c|c|c|c|}
\hline & & & Doméstico \\
\hline Ano & Oferta de assentos & $\begin{array}{r}\begin{array}{r}\text { Passageiros transportados } \\
\text { pagos }\end{array} \\
\end{array}$ & $\begin{array}{r}\text { Ociosidade- } \\
\text { ASK } \\
\end{array}$ \\
\hline 2008 & 75.371 .445 .443 & 49.710 .841 .604 & 25.660 .603 .839 \\
\hline 2009 & 86.291.010.306 & 56.846.933.658 & 29.444.076.648 \\
\hline 2010 & 102.731 .430 .608 & 70.279.463.281 & 32.451 .966 .327 \\
\hline 2011 & 116.095 .569 .545 & 81.461989 .545 & 34.633 .579 .000 \\
\hline 2012 & 119.337 .475 .449 & 87.046 .717 .803 & 32.290 .757 .646 \\
\hline 2013 & 115.907 .532 .089 & 88.241 .919 .927 & 27.665 .612 .162 \\
\hline
\end{tabular}

Fonte: ANAC (2013)

Este aumento da oferta de assentos não foi um bom indicador para a indústria porque a demanda de passageiros é bastante inferior, ou seja, atualmente a indústria enfrenta problemas com a atual supercapacidade, cerca de 28 bilhões de assentos-quilômetros ofertados em 2013. Uma das principais consequências da supercapacidade é a necessidade de redução do preço médio dos preços de venda dos produtos, a Figura 23 mostra a evolução do ASK e do preço médio da tarifa da indústria brasileira de aviação civil.

Figura 23 - Evolução de assentos ofertados e da tarifa média

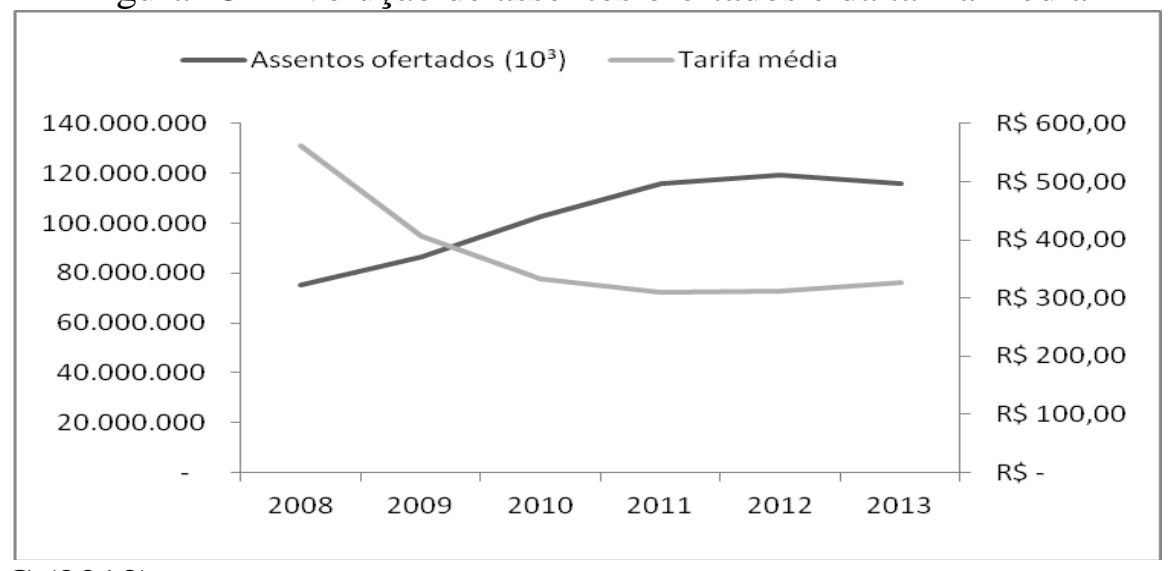

Fonte: ANAC (2013).

Ao comparar o ano de 2008 com 2013 constata-se que houve uma redução de $52 \%$ no valor médio da tarifa pratica na indústria enquanto que a oferta de assentos cresceu cerca de $150 \%$. 
Essa capacidade ociosa vem gerando elevados custos de operação, o Quadro 13 mostra o quanto as companhias aéreas perderam durante o período analisado.

Quadro 13: Perdas geradas pela capacidade ociosa

\begin{tabular}{|r|r|r|r|r|}
\hline Ano & ASK ocioso & $\begin{array}{r}\text { Custo de assentos } \\
\text { quilômetros ofertados - } \\
\text { CASK (R\$) }\end{array}$ & Custo anual & Aproveitamento \\
\hline $\mathbf{2 0 0 8}$ & 25.660 .603 .839 & 0,13 & 3.335 .878 .499 & $72,8 \%$ \\
\hline $\mathbf{2 0 0 9}$ & 29.444 .076 .648 & 0,16 & 4.632 .769 .023 & $70,6 \%$ \\
\hline $\mathbf{2 0 1 0}$ & 32.451 .966 .327 & 0,16 & 5.186 .522 .055 & $74,4 \%$ \\
\hline $\mathbf{2 0 1 1}$ & 34.633 .579 .000 & 0,17 & 6.053 .835 .340 & $75,4 \%$ \\
\hline $\mathbf{2 0 1 2}$ & 32.290 .757 .646 & 0,20 & 6.342 .256 .458 & $76,7 \%$ \\
\hline $\mathbf{2 0 1 3}$ & 27.665 .612 .162 & 0,21 & 5.798 .876 .886 & $78,1 \%$ \\
\hline Média & 30.357 .765 .937 & 0,17 & 5.225 .023 .044 & $74,7 \%$ \\
\hline
\end{tabular}

Fonte: ANAC (2013).

O custo médio anual da capacidade ociosa foi de aproximadamente $\mathrm{R} \$ 5,30$ bilhões, nota-se que uma redução de $59,00 \%$ deste item seria suficiente para atingir o ponto de equilíbrio financeiro no ano de 2013.

Há períodos onde se observa o aumento da taxa de aproveitamento ao passo que o valor absoluto da capacidade ociosa aumenta. Isso se dá porque o aproveitamento é calculado por RPK/ASK, a base de comparação mede a razão entre uma variável e outra. Quando se elevam os níveis de oferta e de demanda pode-se encontrar um quociente maior e uma diferença entre as variáveis maior, isso mostra que o indicar de aproveitamento não reflete de maneira absoluta o aproveitamento da oferta de assentos, uma vez que leva a entender que um aumento do aproveitamento está associado a uma diminuição na ociosidade. Fato que não vem ocorrendo nos últimos seis anos. (Ver anexo I).

Essa volumosa oferta de assentos é resultante da necessidade de aumento de parcelas de marcado por parte das empresas. A expansão das operações é o principal fator que impulsiona a competição entre as companhias aéreas brasileiras. É possível notar no Quadro 14 que houve sucessivas alternâncias de posições no G4 além que haver tendências de parcelas de mercado divergentes. 
Quadro 14 - Parcelas de mercado das principais companhias brasileiras em RPK

\begin{tabular}{|r|r|r|r|r|r|r|r|}
\hline 2008 & & 2009 & & 2010 & & 2011 & \\
\hline TAM & $48,0 \%$ & TAM & $45,5 \%$ & TAM & $42,5 \%$ & TAM & $40,0 \%$ \\
\hline Gol & $27,8 \%$ & $\begin{array}{r}\text { Gol/ } \\
\text { Varig }\end{array}$ & $40,4 \%$ & $\begin{array}{r}\text { Gol/ } \\
\text { Varig }\end{array}$ & $39,7 \%$ & $\begin{array}{r}\text { Gol/ } \\
\text { Varig }\end{array}$ & $37,4 \%$ \\
\hline Varig & $17,2 \%$ & Webjet & $4,4 \%$ & Azul & $6,0 \%$ & Azul & $8,6 \%$ \\
\hline Avianca & $2,8 \%$ & Azul & $3,7 \%$ & Webjet & $5,7 \%$ & Webjet & $5,5 \%$ \\
\hline CR4 & $95,8 \%$ & & $94,0 \%$ & & $93,9 \%$ & & $91,5 \%$ \\
\hline HHI & 0,34 & & 0,37 & & 0,35 & & 0,31 \\
\hline $\begin{array}{c}\text { Lucro } \\
\text { Líquido } \\
\text { R\$ 10 }\end{array}$ & $-3.254 .773,61$ & & $1.542 .917,13$ & & $718.031,17$ & & $-1.592 .910,95$ \\
\hline
\end{tabular}

\begin{tabular}{|r|r|r|r|}
\hline 2012 & 2013 & \\
\hline TAM & $40,3 \%$ & TAM & $39,6 \%$ \\
\hline Gol/Varig & $33,9 \%$ & $\begin{array}{c}\text { Gol/Varig/ } \\
\text { Webjet }\end{array}$ & $35,4 \%$ \\
\hline Azul & $10,0 \%$ & Azul/TRIP & $17,0 \%$ \\
\hline Avianca & $5,4 \%$ & Avianca & $7,2 \%$ \\
\hline $\mathrm{CR} 4$ & $89,6 \%$ & & $99,1 \%$ \\
\hline $\mathrm{HHI}$ & 0,29 & & 0,32 \\
\hline Lucro Líquido $\mathrm{R} \$ 10^{3}$ & $-3.463 .830,70$ & & $-2.400 .622,00$ \\
\hline
\end{tabular}

Fonte: ANAC (2013).

Durante o período 2008-2013, houve a predominância das companhias TAM e GOL na indústria, porém, as duas apresentaram tendências de crescimento e estratégias de expansão divergentes. A TAM obteve reduções gradativas de participação de mercado mantendo as mesmas estratégias de captação de clientes, já a Gol adotou uma estratégia agressiva, a companhia surgiu no mercado como uma low cost low fare e seu principal artifício utilizado para expandir a participação no mercado foi a incorporação de outras empresas.

Em 2008 a Gol incorporou a Varig, os efeitos foram bastante relevantes, uma vez que esta deixou de ter uma participação de $27,83 \%$ e obteve $40,40 \%$ do mercado no ano seguinte. Em seguida perdeu fatias de mercado durante três anos consecutivos em decorrência da maior participação da companhia AZUL. Em meio às reduções de participação no mercado, a Gol em 2012 realizou a incorporação da companhia Webjet, esse movimento de mercado gerou um incremento de $1,48 \%$ na sua participação.

No mesmo ano, a companhia aérea Azul realizou uma fusão com a TRIP que gerou um incremento de $6,97 \%$ da participação no mercado. A indústria ficou altamente concentrada após as três fusões realizadas uma vez que $99,09 \%$ do mercado é dominado por apenas quatro companhias aéreas.

Algo relevante que deve ser observado é o resultado operacional líquido do setor nos períodos posteriores às fusões. No ano de 2009 , logo após a fusão entre a companhia Gol e a VARIG houve uma expressiva diferença entre resultado operacional líquido equivalente a $R$ \$ 4,797 Página 72 
bilhões, quando comparado com o resultado de 2008. Nesta ocasião, a indústria saiu de um elevado prejuízo e passou a operar com lucro no ano seguinte.

Nos períodos posteriores houve uma pequena e gradual redução na concentração da indústria e uma queda gradativa dos resultados. Em 2012 a indústria teve o seu menor nível de concentração atingindo $89,60 \%$ no indicador CR4 e novamente voltou a operar com déficit (R\$ - 3,463 bilhões).

Porém, no mesmo ano houve duas fusões (Gol e Webjet, Azul e TRIP) gerando um CR4 equivalente a $99,09 \%$. O impacto na indústria foi a redução do prejuízo financeiro em $R \$$ 1,063 bilhões, encerrando o período com um resultado operacional líquido de $\mathrm{R} \$-2,40$ bilhões.

Portanto, é possível observar que a competição impulsiona as companhias a buscar economias de escala. Isso vem gerando uma elevado nível de assentos ofertados ociosos, traduzidos em elevação de custo.

Há também uma relação direta entre a rentabilidade e o nível de concentração. Nos períodos onde houve uma redução na concentração, houve queda no desempenho financeiro, bem como melhora no desempenho financeiro impactado pelas fusões que aumentaram o nível de concentração. É possível observar que as fusões têm se tornado cada vez mais frequentes caraterizando uma menor disposição por parte das companhias aéreas em competir. Um fator que reforça este argumento é a evolução da volatilidade da tarifa aérea média mensal na indústria.

Figura 24: Evolução da volatilidade da tarifa aérea média da indústria.

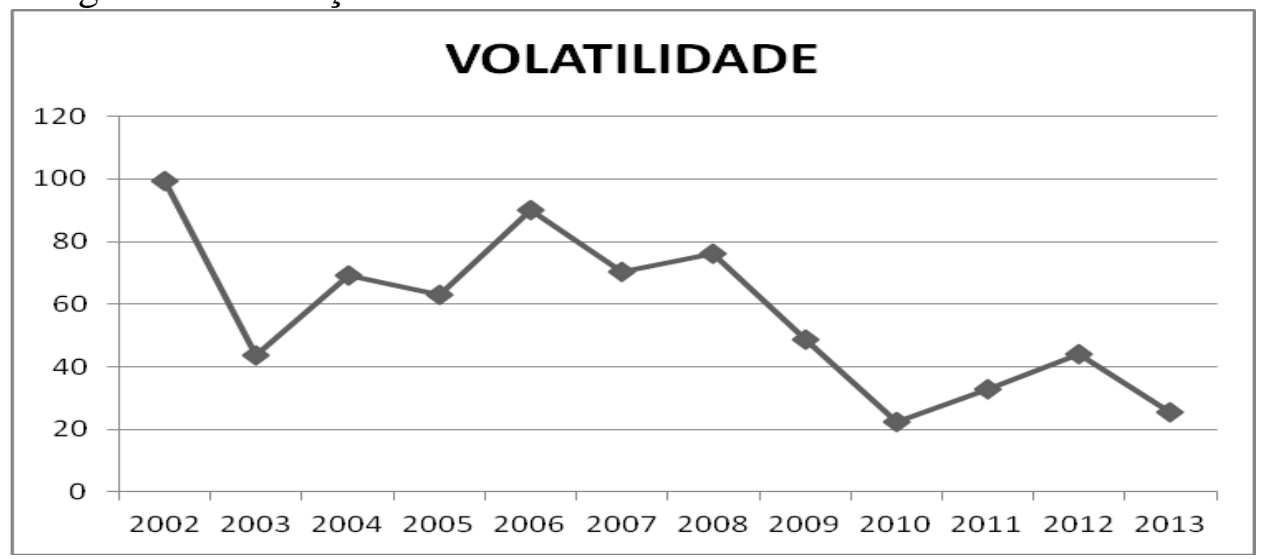

Fonte: ANAC (2013).

A Figura 24 mostra que a disputa de preços vem diminuindo nos últimos anos, atingindo os seus menores patamares entre 2010 e 2013.

A análise de regressão linear multivariada realizada com o auxílio do MS - Excel ® buscou verificar se há uma relação entre os itens que refletem as forças competitivas e os resultados financeiros da indústria. Tomou-se como variável dependente o lucro líquido da indústria (R\$) e como variáveis independentes (explicativas) o excesso de capacidade (\%)-(X1), o percentual de custo com combustível de aviação no custo total (X2), a receita de voo (R\$)(X3), a volatilidade da tarifa aérea média mensal $(\sigma)-(\mathrm{X} 4)$ e o percentual de compras de bilhetes por intervalo de tarifa aérea real (X5). Foram utilizados os dados do anuário do transporte aéreo da ANAC (2013) referente ao período 2003-2013. As variáveis que estão em Página 73 
unidades monetárias foram colocadas em valores de 01/12/2013. Essa padronização foi feita com o auxílio da ferramenta "Calculadora do Cidadão" - BCB, com atualização feita pelo IPCA.

A variável excesso de capacidade representa a força "entrantes potenciais" por ser uma barreira à entrada, o percentual de compras de bilhetes por intervalo de tarifa aérea real representa a força " poder de barganha dos consumidores", uma vez que reflete capacidade dos compradores de acessar preços mais baixos e a volatilidade da tarifa aérea média mensal representa a força "competição" (maiores volatilidades representam ocorrência de maiores disputas de preço).

O percentual de custo com combustíveis reflete o "poder de barganha dos fornecedores", quanto maior o poder do fornecedor maior será a sua capacidade de aumentar preço de venda do seu produto causando impacto direto nos custos dos seus clientes.

Para representar o poder de barganha dos compradores utilizou-se as oito faixas de preço de bilhetes de passagem aérea em que as compras mais se concentraram ao longo do período 2003-2013. Cada uma delas sendo candidata à variável explicativa. Os testes apontaram insignificância estatística para todas as faixas de preço dos bilhetes (Anexo 2). Deste modo conclui-se que as variáveis que representam o lucro da indústria são o excesso de capacidade, o percentual de custo com combustível de aviação no custo total, a receita de voo e a volatilidade da tarifa aérea real. Os resultados da Regressão são apresentados no Quadro 15.

Quadro 15: Resumo dos resultados.

\begin{tabular}{|c|c|c|c|c|c|}
\hline \multicolumn{2}{|c|}{ Estatística de regressão } & & & & \\
\hline $\mathrm{R}$ múltiplo & 0,978759002 & & & & \\
\hline R-Quadrado & 0,957969185 & & & & \\
\hline $\begin{array}{r}\text { R-quadrado } \\
\text { ajustado } \\
\end{array}$ & 0,929948641 & & & & \\
\hline Erro padrão & $560.071 .876,47$ & & & & \\
\hline Observações & 11 & & & & \\
\hline ANOVA & & & & & \\
\hline & $g l$ & $S Q$ & $M Q$ & $F$ & $\begin{array}{r}\text { Fde } \\
\text { significação }\end{array}$ \\
\hline Regressão & 4 & $4,28966 \mathrm{E}+19$ & $1,07241 \mathrm{E}+19$ & 34,18810155 & 0,000287642 \\
\hline Resíduo & 6 & $1,88208 \mathrm{E}+18$ & $3,13681 \mathrm{E}+17$ & & \\
\hline Total & 10 & $4,47786 \mathrm{E}+19$ & & & \\
\hline & Coeficientes & Erro padrão & Stat $t$ & valor- $P$ & 95\% inferiores \\
\hline Interseção & $44.218 .156 .481,90$ & 5609411059 & 7,882851875 & 0,0002208 & 30492422110 \\
\hline Variável X 1 & - 33.944.551.391,79 & 7298406696 & $-4,650953668$ & 0,003500218 & -51803109195 \\
\hline Variável X 2 & - 737.178.986,80 & $\begin{array}{r}80248227,7 \\
2 \\
\end{array}$ & $-9,186233862$ & 9,37791E-05 & $-933539325,9$ \\
\hline Variável X 3 & $-0,30$ & 0,08410793 & $-3,599227133$ & 0,01137706 & $-0,508528232$ \\
\hline Variável X 4 & - 37.476.264,17 & $\begin{array}{r}13012952,4 \\
1\end{array}$ & $-2,879920175$ & 0,028060665 & $-69317811,57$ \\
\hline
\end{tabular}


Os resultados mostraram significância global em um intervalo de confiança de $95 \%$ apontados pelo teste $\mathrm{F}$, ou seja, as quatro variáveis combinadas podem explicar a variável dependente. No teste de significância individual de cada $\beta$ ambas as quatro variáveis apresentaram significância estatística. A estatística Durbin-Watson (2,02415) garante que os resíduos da regressão não estão correlacionados serialmente. O coeficiente de explicação, $\mathrm{R}^{2}$, é igual a $95,79 \%$.

$\hat{Y}=44.218 .156 .481,90-33.944 .551 .391,79 . X 1-737.178 .986,80 . \quad \mathrm{X} 2-0,30 . \mathrm{X} 3-$ 37.476.264,17. X4

Os resultados apontam que entre as variáveis explicativas, a excesso de capacidade e o percentual de custo com combustível apresentam os maiores coeficientes betas estimados, ou seja, estima-se que para cada unidade incremental destes se observe muitas unidades negativas no lucro líquido da indústria.

Para cada percentual de receita, estima-se $-0,30$ unidades de lucro líquido na indústria, isso mostra que o aumento obervado nas receitas nos últimos tempos não tem sido um fator capaz de melhorar os resultados financeiros. Portanto, um caminho viável para melhorar os resultados da indústria tende a ser a adoção de medidas que objetivem reduzir o percentual de custo com combustíveis, bem como a redução da capacidade ociosa.

Visando verificar se a equação estimada apresenta erro de especificação aplicou-se o teste RESET de Hamsey com o auxílio do software estatístico Gretl. Os resultados estão apresentados no Quadro 16.

Quadro16: Teste de erro de especificação.

\begin{tabular}{|r|r|r|r|r|}
\hline \multicolumn{7}{|c|}{ Regressão auxiliar para o teste de especificação RESET } \\
\hline \multicolumn{6}{|c|}{ Estimativas OLS usando as 11 observações 2003-2013 } \\
\hline Variável dependente: Lucro Líquido da Indústria \\
\hline VARIÁVEL & COEFICIENTE & ERRO PADRÃO & ESTAT. T & P-VALOR \\
\hline const & $4,84 \mathrm{E}+10$ & $1,83 \mathrm{E}+10$ & 2,643 & $0,05739 *$ \\
\hline Excesso de Capacidade & $-3,79 \mathrm{E}+10$ & $1,97 \mathrm{E}+10$ & $-1,924$ & 0,12663 \\
\hline Participação percentual do combustível no & & & & \\
custo & $-8,06 \mathrm{E}+08$ & $3,16 \mathrm{E}+08$ & $-2,551$ & $0,06322^{*}$ \\
\hline Receita de voo & $-3,18 \mathrm{E}-01$ & $1,12 \mathrm{E}-01$ & $-2,847$ & $0,04656^{*}$ \\
\hline Volatilidade da tarifa aérea mensal & $-4,13 \mathrm{E}+07$ & $1,90 \mathrm{E}+07$ & $-2,178$ & $0,09495^{*}$ \\
\hline$(\hat{\mathrm{Y}})^{2}$ & $-4,87 \mathrm{E}+11$ & $1,34 \mathrm{E}-10$ & $-0,364$ & 0,73462 \\
\hline$(\hat{\mathrm{Y}})^{3}$ & $0,00 \mathrm{E}+00$ & $0,00 \mathrm{E}+00$ & $-0,372$ & 0,72872 \\
\hline Estatística de teste: $\mathrm{F}=0,074595$, & & & & \\
\hline com $\mathrm{p}$-valor $=\mathrm{P}(\mathrm{F}(2,4)>0,0745954)=0,929$ & & & & \\
\hline
\end{tabular}

O resultado do teste RESET apontou mostra que a inclusão de uma função não linear na equação estimada não gera significância estatística, ou seja, a equação estimada não contém erro de especificação. Cabe ressaltar que não há referencial teórico que sustente alguma afirmação sobre os sinais esperados dos $\beta$ estimados, fato que traz uma grande dificuldade à pesquisa.

Com o aporte teórico do modelo de Porter, partiremos do princípio de que a ocorrência de $\beta$ estimados negativos representam altas intensidades das forças e $\beta$ estimados positivos 
representam baixas intensidades. Segundo Porter (1979) quanto mais intensas forem as forças competitivas menor será potencial de lucro da indústria em questão.

A equação estimada apresenta algumas informações relevantes. A primeira delas aponta que as variáveis elencadas para representar o poder de barganha dos compradores não apresentaram significância estatística. Logo, é a força mais fraca da indústria.

A variável que representa a ameaça novos participantes apresentou o maior $\beta$ estimado. Quanto maiores as barreiras à entrada menor é a ameaça de novos participantes, Porter (1979). Sendo ela uma barreira à entrada, entende-se que a ameaça de novos participantes é baixa. Logo, é a segunda força mais fraca.

A variável que representa o poder de barganha dos fornecedores apresentou o segundo maior $\beta$ estimado. Quanto maior o poder de barganha, maior será a sua capacidade de negociar preços. Desse modo, entende-se que o poder de barganha dos fornecedores é a força competitiva mais intensa.

A variável que representa a competição apresentou o terceiro maior $\beta$ estimado. Desse modo, entende-se que a competição é a segunda maior força em termos de intensidade. Não foi possível relacionar a força ameaça de substitutos em decorrência da ausência de dados de tarifa do substitutos próximo do transporte aéreo (transporte rodoviário). A Figura 25 apresenta uma síntese da intensidade das forças competitivas da indústria brasileira de aviação civil. Nesta representação observa-se que a força mais intensa está no centro e a menos intensa está na última camada da figura.

Figura 25: Classificação das forças competitivas da indústria brasileira de aviação civil por nível de intensidade.

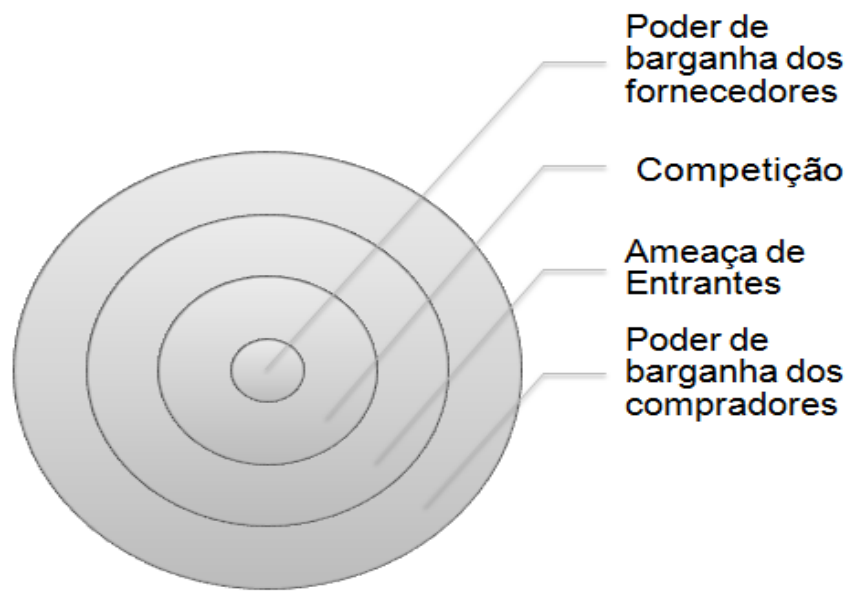

Desse modo é possível visualizar as forças competitivas mais intensas na indústria, ou seja, por meio desta representação pode-se ter noção de quais são os principais fatores que estão impactando negativamente no lucro líquido da indústria. 


\subsection{A construção dos cenários}

Segundo Schwartz (2006) e Van der Hejiden (2004), os cenários são ferramentas úteis para simular ambientes alternativos futuros baseados em percepções, ou seja, auxiliam na avaliação de tendências, dando uma visão mais clara e abrangente do futuro.

Antunes e Dias (2007) salientam que a análise de decisão visa desenvolver métodos lógicos para melhorar a tomada de decisões pelos indivíduos e pelas organizações, com ênfase no desenvolvimento de modelos para decidir em condições de incerteza e considerando múltiplos objetivos.

Ringland (1988) aponta a relevância do método de análise dos impactos tendenciais. De acordo com o autor esta metodologia de planejamento de cenários baseia-se em uma projeção independente de variáveis-chave, visando lidar com eventos incertos. Trata-se de uma metodologia amplamente utilizada na elaboração de instrumentos voltados para tomada de decisão empresarial desde os anos 70 .

Segundo Borousch e Thomas (1992:28-29), a análise de impactos tendenciais pode ser dividida em três etapas: preparação, desenvolvimento e apresentação/utilização. A primeira refere-se à definição do foco da simulação e de suas forças motrizes, a segunda constrói vários cenários a serem detalhados por meio de projeções para cada um deles e na terceira cria-se um documento que expõe as implicações de cada um deles.

Como de hábito, foram considerados três cenários: otimista, realista e pessimista. Há duas variáveis de risco, uma é a receita de passagens e a outra é rubrica de custo com combustíveis, tudo o mais constante. A receita de passagens é uma rubrica da DRE do setor brasileiro de aviação civil, a rubrica de custo foi obtida por meio da estratificação da rubrica de custo.

A tabela 1 apresenta o valor do custo de combustíveis necessário para zerar o VPL no cenário intermediário foi obtido por meio da função atingir meta do software Microsoft Excel ®. Segundo o Instituto Brasileiro de Tributação (2014), 46,72\% do custo total com o combustível é composto por impostos, a simulação mostrou que uma redução 9,87\% ( $\mathrm{R} \$ 8.967 .335,00$ valor obtido após zerar o VPL) deste total seria suficiente para atingir o ponto de equilíbrio financeiro. 
Tabela 1: Ponto de equilíbrio - custo com combustíveis, $\mathrm{R} \$ 10^{3}$

\begin{tabular}{|c|c|c|c|}
\hline DRE $2014^{2}$ (Pessimista) & $\mathrm{R} \$ 103$ & DRE $2014^{2}$ (Intermediário) & $\mathrm{R} \$ 103$ \\
\hline Receita de passagens & 32.529 .766 & Receita de passagens & 32.529 .766 \\
\hline Custo operacional & 30.475 .732 & Custo operacional & 28.075 .105 \\
\hline Custo com Tripulação & 2.936 .574 & Custo com Tripulação & 2.936 .574 \\
\hline $\begin{array}{l}\text { Custo com Combustíveis } \\
\text { Custo com Depreciação de }\end{array}$ & 11.367.962 & $\begin{array}{l}\text { Custo com Combustíveis } \\
\text { Custo com Depreciação de }\end{array}$ & 8.967 .335 \\
\hline Equipamentos de Voo & 1.128 .713 & Equipamentos de Voo & 1.128 .713 \\
\hline $\begin{array}{ll}\text { Custo com Arrendamento, } \\
\text { Manutenção e Seguro das } \\
\text { Aeronaves } & \\
\text { Custo com Tarifas }\end{array}$ & 5.170 .036 & $\begin{array}{l}\text { Custo com Arrendamento, } \\
\text { Manutenção e Seguro das } \\
\text { Aeronaves } \\
\text { Custo com Tarifas }\end{array}$ & 5.170 .036 \\
\hline Aeroportuárias & 772.393 & Aeroportuárias & 772.393 \\
\hline $\begin{array}{l}\text { Custo com Tarifas de Navegação } \\
\text { Aérea }\end{array}$ & 1.041 .274 & $\begin{array}{l}\text { Custo com Tarifas de } \\
\text { Navegação Aérea }\end{array}$ & 1.041 .274 \\
\hline Custos Indiretos & 2.681 .343 & $\begin{array}{l}\text { Custos Indiretos } \\
\text { Despesas Administrativas }\end{array}$ & 2.681 .343 \\
\hline Despesas Administrativas Gerais & 2.219 .018 & Gerais & 2.219 .018 \\
\hline Outras Despesas Operacionais & 3.158 .418 & Outras Despesas Operacionais & 3.158 .418 \\
\hline Lucro bruto & 2.054 .034 & Lucro bruto & 4.454 .661 \\
\hline Outras despesas & 2.517 .823 & Outras despesas & 2.517 .823 \\
\hline Resultado operacional & -463.789 & Resultado operacional & 1.936 .838 \\
\hline Receita financeira & 1.291 .167 & Receita financeira & 1.291 .167 \\
\hline Despesa financeira & -3.604 .561 & Despesa financeira & -3.604 .561 \\
\hline Resultado financeiro & -2.313 .394 & Resultado financeiro & -2.313 .394 \\
\hline Resultado antes do IR/CCSL & -2.777 .183 & Resultado antes do IR/CCSL & -376.556 \\
\hline IR/CCSL & 376.556 & IR/CCSL & 376.556 \\
\hline Lucro líquido & -2.400 .627 & Lucro líquido & 0 \\
\hline
\end{tabular}

Utilizando o mesmo princípio, verificou-se o percentual necessário de redução de capacidade ociosa necessária para atingir o ponto de equilíbrio. Uma vez que o impacto desta seria direcionado às rubricas "Custo com depreciação de equipamentos de voo" e "Custo com arrendamento, manutenção e seguro das aeronaves". Atualmente somam um montante de R\$ 6.298.749.148,54 (21,9\% de capacidade ociosa), após atingir o ponto de equilíbrio R\$ 3.898.122.000,00 (13,55\% de capacidade ociosa), ou seja, o ponto de equilíbrio poderia ser alcançado por meio da redução $8,35 \%$ do montante de impostos incidentes no querosene de aviação. 
Tabela 2: Ponto de equilíbrio - custo com arrendamento e manutenção de aeronaves, $\mathrm{R} \$ 10^{3}$

\begin{tabular}{|c|c|c|c|}
\hline DRE $2013^{2}$ (Pessimista) & $\mathrm{R} \$ 103$ & DRE $2014^{2}$ (Intermediário) & $\mathrm{R} \$ 103$ \\
\hline Receita de passagens & 32.529 .766 & Receita de passagens & 32.529 .766 \\
\hline Custo operacional & 30.475 .732 & Custo operacional & 28.075 .105 \\
\hline Custo com Tripulação & 2.936 .574 & Custo com Tripulação & 2.936 .574 \\
\hline Custo com Combustíveis & 11.367 .962 & Custo com Combustíveis & 11.367 .962 \\
\hline $\begin{array}{l}\text { Custo com Depreciação de } \\
\text { Equipamentos de Voo/ Custo } \\
\text { com Arrendamento, Manutenção }\end{array}$ & & $\begin{array}{l}\text { Equipamentos de Voo/ Custo } \\
\text { com Arrendamento, } \\
\text { Manutenção e Seguro das }\end{array}$ & \\
\hline e Seguro das Aeronaves & $6.298 .749,14$ & Aeronaves & 3.898 .122 \\
\hline Custo com Tarifas & & Custo com Tarifas & \\
\hline Aeroportuárias & 772.393 & Aeroportuárias & 772.393 \\
\hline Custo com Tarifas de Navegação & & Custo com Tarifas de & \\
\hline Aérea & 1.041 .274 & Navegação Aérea & 1.041 .274 \\
\hline Custos Indiretos & 2.681 .343 & $\begin{array}{l}\text { Custos Indiretos } \\
\text { Despesas Administrativas }\end{array}$ & 2.681 .343 \\
\hline Despesas Administrativas Gerais & 2.219 .018 & Gerais & 2.219 .018 \\
\hline Outras Despesas Operacionais & 3.158 .418 & Outras Despesas Operacionais & 3.158 .418 \\
\hline Lucro bruto & 2.054 .034 & Lucro bruto & 4.454 .661 \\
\hline Outras despesas & 2.517 .823 & Outras despesas & 2.517 .823 \\
\hline Resultado operacional & -463.789 & Resultado operacional & 1.936 .838 \\
\hline Receita financeira & 1.291 .167 & Receita financeira & 1.291 .167 \\
\hline Despesa financeira & -3.604 .561 & Despesa financeira & -3.604 .561 \\
\hline Resultado financeiro & -2.313 .394 & Resultado financeiro & -2.313 .394 \\
\hline Resultado antes do IR/CCSL & -2.777 .183 & Resultado antes do IR/CCSL & -376.556 \\
\hline IR/CCSL & 376.556 & IR/CCSL & 376.556 \\
\hline Lucro líquido & -2.400 .627 & Lucro líquido & 0 \\
\hline
\end{tabular}

Conforme proposto por Rocha, Sousa e Campos (2015) será considerada a DRE de 2013 e o lucro líquido setorial estimado para 2014 por IATA (2013), equivalente a US\$ 1,5 bilhão convertidos a uma taxa de R $\$ 2,26 / \mathrm{US} \$ 1,00$. Os resultados indicaram um risco de $39,56 \%$, onde a rubrica de risco era a receita. $\mathrm{O}$ valor desta rubrica necessário para obter o resultado líquido estimado pela IATA de R \$ 3,4 bilhões foi de R \$38.770.393.000,00.

Visando elaborar uma análise que objetiva avaliar o risco de rentabilidade, foram utilizadas as mesmas premissas, considerando alguns possíveis ajustes nas rubricas de risco referentes à ociosidade e ao percentual de imposto no combustível. A descrição dos cenários é apresentada no Quadro 19. 
Quadro 19: Descrição dos cenários para a receita de passagens

\begin{tabular}{|l|l|}
\hline \multicolumn{1}{|c|}{ Cenário } & \multicolumn{1}{c|}{ Descrição } \\
\hline Pessimista & $\begin{array}{l}\text { A receita de passagens é a mesma obtida pelo setor em 2013, no qual } \\
\text { resultou em um lucro líquido de R\$ -2,4 bilhões. }\end{array}$ \\
\hline Intermediário & $\begin{array}{l}\text { O custo com combustíveis necessário para tornar o lucro líquido do setor } \\
\text { igual a R } \$ 0,00 \text { em 2014. }\end{array}$ \\
\hline Otimista & $\begin{array}{l}\text { A receita de passagens é a que torna o lucro líquido do setor igual a R } \$ 3,4 \\
\text { bilhões em 2013 (ROCHA, SOUSA e CAMPOS, 2015) juntamente com o } \\
\text { valor de imposto necessário para atingir o ponto de equilíbrio e o valor de } \\
\text { depreciação e manutenção necessário para atingir o ponto de equilíbrio. }\end{array}$ \\
\hline
\end{tabular}

Com o emprego da ferramenta Atingir meta e adotando o princípio ceteris paribus, foi possível obter a receita de passagens do cenário otimista, no valor de $\mathrm{R} \$ 3,4$ bilhões, mantidas inalteradas todas as outras rubricas (Tabela 3). O cenário otimista final será composto por duas rubricas de risco: a receita obtida no atingir meta e o custo necessário alcançar o ponto de equilíbrio financeiro do setor.

DRE $2014^{2}$ (Cenário Otimista

\begin{tabular}{|c|c|c|c|}
\hline DRE $2014^{2}$ (Atingir meta) & $\mathrm{R} \$ 103$ & Final) & $\mathrm{R} \$ 103$ \\
\hline Receita de passagens & 32.529 .766 & Receita de passagens & 38.770 .393 \\
\hline Custo operacional & 30.475 .732 & Custo operacional & 25.674 .478 \\
\hline Custo com Tripulação & 2.936.574 & Custo com Tripulação & 2.936 .574 \\
\hline Custo com Combustíveis & 11.367 .962 & Custo com Combustíveis & 8.967 .335 \\
\hline Custo com Depreciação de & & Custo com Depreciação de & \\
\hline $\begin{array}{l}\text { Equipamentos de Voo/ Custo } \\
\text { com Arrendamento, }\end{array}$ & & $\begin{array}{l}\text { Equipamentos de Voo/ Custo } \\
\text { com Arrendamento, }\end{array}$ & \\
\hline Manutenção e Seguro das & & Manutenção e Seguro das & 3.898 .122 \\
\hline Aeronaves & 6.298 .749 & Aeronaves & \\
\hline Custo com Tarifas & & Custo com Tarifas & \\
\hline Aeroportuárias & 772.393 & Aeroportuárias & 772.393 \\
\hline Custo com Tarifas de & & Custo com Tarifas de & \\
\hline Navegação Aérea & 1.041.274 & Navegação Aérea & 1.041 .274 \\
\hline Custos Indiretos & 2.681 .343 & Custos Indiretos & 2.681 .343 \\
\hline Despesas Administrativas & & Despesas Administrativas & \\
\hline Gerais & 2.219.018 & Gerais & 2.219 .018 \\
\hline Outras Despesas Operacionais & 3.158 .418 & Outras Despesas Operacionais & 3.158 .418 \\
\hline Lucro bruto & 2.054 .034 & Lucro bruto & 11.511 .288 \\
\hline Outras despesas & 2.517 .823 & Outras despesas & 2.517 .823 \\
\hline Resultado operacional & -463.789 & Resultado operacional & 8.993 .465 \\
\hline Receita financeira & 1.291 .167 & Receita financeira & 1.291 .167 \\
\hline Despesa financeira & -3.604 .561 & Despesa financeira & -3.604 .561 \\
\hline Resultado financeiro & -2.313 .394 & Resultado financeiro & -2.313 .394 \\
\hline Resultado antes do IR/CCSL & -2.777 .183 & Resultado antes do IR/CCSL & 7.369 .784 \\
\hline IR/CCSL & 376.556 & IR/CCSL & 376.556 \\
\hline
\end{tabular}

Lucro líquido -2.400.627 Lucro líquido 8.641 .254 
A tabela 4 resume os valores da rubrica de risco da DRE, receita de passagens, para cada um dos três cenários considerados.

Tabela 4: Cenários para a receita de passagens, em 2014

\begin{tabular}{ccccc}
\hline \multicolumn{5}{c}{ Cenário (valores em R $\$ 10^{3}$ ) } \\
\hline Cenário & Pessimista & Intermediário & Otimista & Distribuição \\
\hline Receita & 32.529 .766 & 32.529 .766 & 38.770 .393 & Uniforme \\
\hline $\begin{array}{c}\text { Custo } \\
\text { (Combustível) }\end{array}$ & 11.367 .962 & 8.967 .335 & 8.967 .335 & Uniforme \\
\hline $\begin{array}{c}\text { Custo } \\
\text { (Arrendamento/depreciação) }\end{array}$ & 6.298 .749 & 6.298 .749 & 3.898 .122 & Uniforme \\
\hline
\end{tabular}

O custo com arrendamento/ depreciação reflete o dispêndio das companhias com a aquisição e manutenção das aeronaves. No ano de 2013 o percentual de capacidade ociosa foi de $21,9 \%$. Os cenários, pessimista e intermediário refletem o total deste custo, considerando o total de ociosidade e o cenário otimista reflete uma redução de $8,35 \%$ do percentual de ociosidade na indústria. Tal redução foi aplicada somente no cenário otimista.

Antes de prosseguir, vale comentar sobre algumas rubricas da DRE de 2013 da Tabela 3. As despesas financeiras dizem respeito principalmente ao arrendamento mercantil de aeronaves. A rubrica contribuição social apresenta valor positivo porque o setor realizou um pequeno crédito junto às autoridades fiscais. A rubrica "imposto de renda" é zero quando a base de cálculo do imposto é menor ou igual à zero. A rubrica custo operacional retrata o custo direto e indireto da operação das aeronaves. Observe-se que o custo operacional é muito elevado. A rubrica outras despesas representa os gastos com os escritórios das companhias.

Vale ressaltar que esta simulação apresenta informações mais completas do que Rocha, Carvalho e Campos (2015), uma vez que o objetivo desta simulação é verificar qual seria o impacto de algumas intervenções que visam reduzir o custo com combustíveis e redução de capacidade ociosa, caso os gestores decidissem por sua implementação.

Mesmo havendo a formação dos cenários otimista, realista e pessimista fez-se necessário o uso da distribuição de probabilidade uniforme na análise de simulação, que foi conduzida com a ajuda do software Crystal Ball@ da Oracle. Este software usa a Simulação Monte Carlo.

A simulação utilizou 50.000 iterações para produzir a estimativa do lucro líquido (LL) de 2014 do setor. Considere a Figura 26 que contém a distribuição do lucro líquido, como gerada pelo Crystal Ball®. A distribuição de frequência reflete 30.000 valores para o lucro líquido; a média é igual a R \$ 3.124.011.000,00 e o desvio-padrão é de $\mathrm{R} \$ 2.058 .890$.

Figura 26: Gráfico da probabilidade de lucro na indústria brasileira de aviação civil $\left(\mathrm{R} \$ 10^{3}\right)$ 


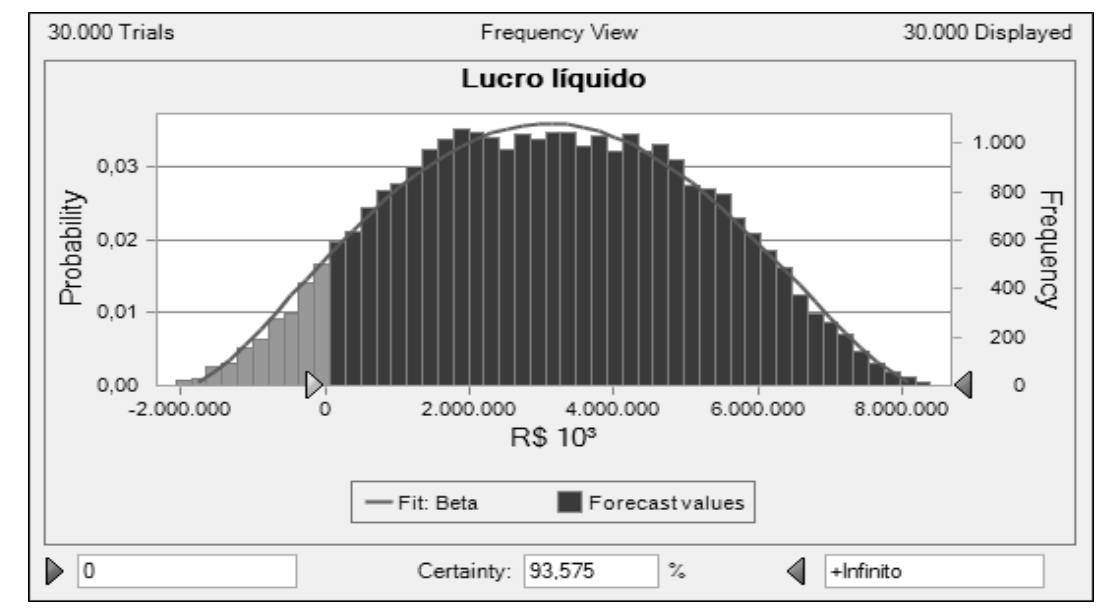

Observe-se que ao adotar os três cenários descritos anteriormente, sendo um pessimista e outro bastante otimista, há uma forte chance de o setor incorrer em prejuízo financeiro. A chance do lucro líquido ficar entre $\mathrm{R} \$-2.400 .626 .984,00$ e $\mathrm{R} \$ 0,00$, no próximo ano , é de $6,425 \%$. Contudo, a probabilidade de lucro operacional líquido estar entre $\mathrm{R} \$ 0,00$ e $\mathrm{R} \$$ 8.641.254.000,00 é de $93,575 \%$.

Comparando estes resultados com os obtidos por Rocha, Sousa e Campos (2015) é possível perceber que a ação de agentes reguladores no sentido de reduzir a capacidade ociosa na indústria e diminuir o ônus dos combustíveis traria uma considerável melhora nos resultados. A chance de prejuízo financeiro sem influência de agentes reguladores encontrada por Rocha, Sousa e Campos (2015) é de 39,04\%. O percentual encontrado por esta dissertação para um cenário com ajustes é de $6,425 \%$ uma redução de $32,615 \%$ no risco da indústria. 


\section{CONCLUSÃO}

Esta dissertação é sobre a indústria nacional de aviação civil. Foram analisados exclusivamente os aspectos financeiros da indústria que apresentou recorrentes déficits nos últimos tempos. O referencial teórico de análise foi o modelo das cinco forças de Porter (1979).

Após analisar o lucro líquido da indústria conclui-se que a hipótese inicial do trabalho foi atestada, os recentes resultados da indústria brasileira de aviação civil podem ser entendidos por meio do modelo teórico de forças competitivas de Porter (1979). Este trabalho se encerra com a apresentação dos resultados obtidos através de uma abordagem quantitativa que buscou relacionar os fatores que vêm gerando maior influência no lucro da indústria.

Cabe ressaltar que o modelo de forças competitivas de Porter (1979) considera a competição interna da indústria como principal fator de influência no potencial de lucro. Sendo assim, tal aplicação somente pode ser considerada em indústria onde há competição.

É neste contexto que reside a principal limitação deste trabalho. O incentivo à competição na aviação civil brasileira é um fato recente, a indústria somente passou a ter uma dinâmica mais próxima a um ambiente de livre concorrência a partir dos anos 2000. Deste modo, a amostra de dados do período de efetiva competição no transporte aéreo brasileiro apresenta um horizonte temporal demasiadamente pequeno para se fazer inferências estatísticas efetivamente confiáveis. Portanto, vale ressaltar que as simulações realizadas neste trabalho serviram para subsidiar alguns entendimentos acerca do assunto, no entanto os resultados quantitativos não devem ser considerados em seus detalhes por conta da pequena amostra utilizada.

Ademais, a força "ameaça de substitutos" não foi considerada no modelo de explicação do lucro líquido. Esta seria representada pelo indicador "taxa marginal de substituição". O motivo da não consideração deu-se em decorrência da ausência dos dados tarifa média praticada do Transporte Interestadual de Passageiros -TRIP, pois a Agência Nacional de Transportes Terrestres- ANTT não tem uma base de dados consolidada contendo os valores finais cobrados pelas empresas.

Em relação aos resultados obtidos, nota-se que a ameaça de novos participantes é baixa porque a atividade apresenta naturalmente uma elevada estrutura de custos, além disso, uma das principais barreiras à entrada é o excesso de capacidade presente na indústria que força as entradas a entrar em operação com uma grande escala. $\mathrm{O}$ excesso de capacidade gera diversos custos, tais como a depreciação, o pagamento dos arrendamentos mercantis e da manutenção. Este item é uma barreira à entrada de novos participantes, $o \beta$ estimado na regressão linear foi o maior. Desse modo pode-se afirmar que há baixa ameaça de novos participantes na indústria.

O poder de barganha dos compradores é fraco uma vez que a rubrica escolhidas para representá-lo não é uma variável explicativa do lucro líquido.

O poder de barganha dos fornecedores é alto. Isso pode ser observado pelo fato de haver um elevado $\beta$ estimado negativo. Evidenciando que durante o período analisado o poder de barganha dos fornecedores de combustível veio impulsionando o prejuízo financeiro. 
$\mathrm{O}$ segundo maior $\beta$ estimado se refere à rubrica que representa a competição. Sendo ele negativo, infere-se que maiores volatilidades da tarifa (disputas de preços) vêm resultando em maiores prejuízos para a indústria.

As rubricas que mais impactaram na rentabilidade da indústria foram a receita, o custo com combustíveis e o custo gerado pela capacidade ociosa. Com base na DRE da indústria referente ao ano de 2013 fornecido pela ANAC, foi possível verificar que tanto a redução de 9,87\% no montante de impostos cobrados no combustível de aviação quanto a redução de 8,35\% no montante de impostos incidentes no combustível de aviação são suficientes para equilibrar o resultado financeiro da indústria.

Ambas as rubricas são variáveis explicativas do lucro líquido da indústria, os quais apresentaram os mais elevados valores para os coeficientes $\beta$ estimados para a regressão linear multivariada.

Após a realização de uma simulação que considerou os efeitos da desoneração de montante de imposto em um percentual de 9,87\% juntamente com a redução de 8,35\% da capacidade ociosa com o valor de receita necessário para atingir o potencial de lucro estimado pela IATA de $\mathrm{R} \$ 3,4$ bilhões, verificou-se que tais aplicações resultariam em uma diminuição do risco de rentabilidade em 32,615\% quando comparada aos resultados obtidos por (ROCHA, SOUSA, CAMPOS, 2015).

Estes resultados são um importante subsídio para os gestores entenderem um pouco mais sobre a dinâmica financeira do setor de modo a visualizar de maneira mais precisa os seus principais gargalos.

Por fim, propõe-se duas sugestões de temas para estudos futuros. O primeiro se refere à realização de uma comparação entre as forças competitivas da indústria brasileira, a indústria americana e a indústria europeia com a utilização de métodos quantitativos. Tal estudo trará grandes informações para os pesquisadores, gestores e profissionais relativos aos níveis de intensidade das forças competitivas.

A segunda se refere à análise da influência de políticas industriais que norteiam a indústria nacional de aviação civil. Em especial a política industrial adotada pela Embraer. 


\section{Referências}

Agência Nacional do Petróleo. Abastecimento em números - 2013. <file:///C:/Users/03528056177/Downloads/70447.pdf>. Acesso em: 02/07/2015.

Agência Nacional de Aviação Civil. Anuário do transporte aéreo 2013. <http://www2.anac.gov.br/estatistica/anuarios.asp>. Acesso em: 05/10/2015.

AGUIAR, D.R.D. e FIQUEIREDO, A. M. Poder de mercado no varejo alimentar: uma análise usando os preços do estado de São Paulo. RESR, 2012.

AMIRI, M., ZANDIEH, M., VAHDANI, B., SOLTANI, R. e ROSHANAEI, V. An Integrated EigenvectorDEA-TOPSISMethodology for Portfolio Risk Evaluation in the FOREX Spot Market. Expert Systems with Applications, Vol. 37 (1), pp. 509-516, 2010.

ANTONI, F. B. A estrutura competitiva da indústria ervateira do Rio Grande do Sul. Julho de 1995. 110 páginas. Dissertação- Programa de Pós-Graduação em Administração da Universidade Federal do Rio Grande do Sul. Porto Alegre-RS, 1995.

ANTUNES, C. H., Dias, L. C. Decisão Perspectivas Interdisciplinares, Coimbra, 2007.

ASSAF, A.N. Mercado Financeiro. 5ª Ed. São Paulo: Atlas, 2003.

Associação Brasileira de Agências de Viagens Corporativas. $<$ http://www.abracorp.org.br/images/estatisticas/Pesquisa-de-Vendas-Abracorp-

2013/A\%C3\%A9reo-Dom-total-de.pdf>. Acesso em: 19/06/2015.

AIRBUS. New Airbus aircraft list prices for 2014. http://www.airbus.com/presscentre/pressreleases/press-release-detail/detail/new-airbusaircraft-list-prices-for-2014/. Acesso em : 07/10/2015.

AIRCRAFT COMPARE.COM. ATR- Aircraft- $\quad$ France. http://www.aircraftcompare.com/manufacture-aircraft/ATR-Aircraft/26. Acesso em: 07/10/2015.

AIRCRAFT COMPARE.COM. ATR-. Boeing - United States. ttp://www.aircraftcompare.com/manufacture-aircraft/Boeing/1. Acesso em: 07/10/2015.

AIRCRAFT COMPARE.COM - $\quad$ Embraer $\quad$ - Brazil. http://www.aircraftcompare.com/manufacture-aircraft/Embraer/4. Acesso em: 07/10/2015.

AIRCRAFT COMPARE.COM. Cessna- United States. http://www.aircraftcompare.com/manufacture-aircraft/Cessna/5. Acesso em: 07/10/2015.

BACK, A.J. Aplicação de análise estatística para identificação de tendências climáticas. Pesquisa Agropecuária, 2001.

BAIN, J. S. "Relation of Profit Rate to Industry Concentration: American Manufacturing. Quarterly Journal of Economics. n. 65 293-324, 1951. 
BAIN, J. S. Barriers to New Competition (Cambrigde, Masss: Harvard University Press, 1956.

BAUER, P., ZLATOPER, T. The determinants of direct air fare to Cleveland: How Competitive? Economic Review. N.25 (1, Q1) 2-9, 1989.

BARRIONUEVO, A. F., LUCINDA, C. R. Teoria da Regulação. Economia do setor público no Brasil. $2^{\text {a }}$ Ed. Rio de Janeiro: Campus. P. 47-71, 2004.

BASEL COMMITTEE ON BANKING SUPERVISION - BCBS. Internacional convergence of capital measurement and capital standards. Base: BCBS, 1988.

BEZERRA, J.F., SILVA, I.E.M e LIMA, R.C. Estudo empírico da operacionalidade do canal de crédito bancário no nordeste e no Brasil. Documentos Técnicos-científicos, 2013.

BIELSCHOWSKY, P., CUSTÓDIO, M. "A Evolução do Setor de Transporte Aéreo Brasileiro”. Revista Eletrônica Novo Enfoque. v. 13, n. 13, pp. 72 - 93,2011.

BINDER, M. P. Discussão da Cadeia de Valor e Estratégias Genéricas de Michael Porter a partir do Caso Gol Transportes Aéreas. 180 páginas. Dissertação - Mestrado em Administração de Empresas/FGV. São Paulo-SP, 2003.

BIRKINSHAW, J., HOOD, N., YOUNG, S.. Subsidiary entrepreneurship, internal and external competitive forces, and subsidiary performance. Internacional Business Review. April 2004.

BORENSTEIN, S. "The Competitive Advantage of a Dominant Airline". Institute of Public Policy Studies Discussion Paper. Univeristy of Michigan, 1989.

BOROUSH, M. A., TOMAS, C. W. Alternative scenarios for the defense industry after 1995, Planning Review, may/jun, 1992: 24-29, 1995.

BRANDENBURGER, A.; NALEBUFF, B. 1996. Co-opetition. 1st edition. New York: Broadway Business.

BRUNI, A. L., FAMÁ, R., SIQUEIRA, J. de O. Análise do risco na avaliação de projetos de investimento: uma aplicação do método de Monte Carlo. Caderno de Pesquisas em Administração, São Paulo, v.1, nº 6, 1998.

BUStO, A. de C., TUROLlA,F. A e OlIVEIRA, A. V. M. Modelagem dos Impactos da Política de Flexibilização na Competição das Companhias Aéreas Brasileiras. Revista Economia e Sociedade. Vol. 15 n.2 327-345, 2006.

CANCIAM, C.A. Aplicação da análise de regressão linear na estimativa da energia de fluxo dos ácidos oleico e palmítico. Revista da Universidade Vale do Rio Verde, 2013.

CANO, W. Crise de 1929: soberania na política econômica e industrialização. In: PRADO, L.C.D. (Org.). Desenvolvimento econômico e crise: ensaios em comemoração aos 80 anos de Maria da Conceição Tavares. Rio de Janeiro: Contraponto; Centro Internacional Celso Furtado, 2012. 
CANTELMO, N.F. e FERREIRA, D.F. Desempenho de testes de normalidade multivariados avaliado por Simulação Monte Carlo. Ciências Agrotécnicas, 2007.

CAN STOCK PHOTO.< http://www.canstockphoto.com.br>. Acesso em: 10/03/2016.

CAPELlETO, L. R. e CORRAR, L. J. Índices de Risco Sistêmico para o Setor Bancário. Revista Contabilidade Financeira. V.19 n. 47 p.6-18. 2008.

CARVALHO, L. H. e AGUIAR, D. R. D.Concentração de mercado e poder de monopsônio na indústria brasileira de esmagamento de soja. Revista de Economia e Agronegócio. Vol.3 $\mathrm{n}^{\circ} 3,2015$.

CHAMBERLIN, E. The theory of monopolistic Competition. Harvard Economic Studies, v.38. (Cambrigde, Mass: Harvard University Press), 1933.

COSTA, F. e GARCIAS, P. M. Concentração de Mercado e Desempenho das Indústrias Brasileiras de Papeal e Celulose- Recorrendo à Modelagem de Fleuriet para Analisar o Paradigma ECD. RCO- Revista de Contabilidade e Organizações. V.3, n.6, p 143-163, 2009.

COSTA, N.L. e SANTANA, A.C. Estudo da Concentração de Mercado ao Longo da Cadeia Produtiva da Soja no Brasil. Revista de Estudos Sociais, 2014.

COURNOT, A. A. Recherches sur lês príncipes mathématiques de La théorie des richesses. Jounal des Savantes. Paris: Hachete, 1838.

CPDOC-FGV. http://cpdoc.fgv.br/ Acesso em: 12/03/2016.

D'ALFONSO,T.; JIANG, C. e BRACAGLIA,V. The effects of competition between air transport and high speed rail on environment. <https://editorialexpress.com/cgibin/conference/download.cgi?db_name=ITEA2014\&paper_id=89>. Acesso em: 10/03/2016.

$\begin{array}{lllllll}\text { Decreto } & 3080, & \text { de } & 10 & \text { de } & \text { junho }\end{array}$ <http://presrepublica.jusbrasil.com.br/legislacao/110954/decreto-3080-99>. Acesso em: 02/07/2015.

DENISE R. B. Economia e Mercado. Paraná: IESDE, 2007.

DIAS, J.A.S. e BORGES, C.L.T.Modelo orientado a objetos para avaliação da confiabilidade composta por Simulação Monte Carlo com representação da geração eólica. Revista Controle \& Automação, 2009.

DOMINGOS, E. M. Estratégia Competitiva na Indústria de Transporte Aéreo Comercial de Passageiros no Brasil. Tese. Universidade Federal do Rio de Janeiro. Rio de Janeiro, 2005.

DOUGLAS, T. J., and RYMAN, J. A. Understanding competitive advantage in the general hospital industry: evaluating strategic competencies. Strategic Management Journal, 2003.

DUARTE, A. M. J. Risco: definições, tipos, medição e recomendações para seu gerenciamento. Bolsa de Mercadorias \& Futuros. (Resenha BM\&F, 114), 1996. 
ERA. European Regions Association. Air and rail: Setting the record straight environment, investment,mobility and political bias. <http://www.eraa.org/sites/default/files/FINAL\%20AMENDED\%20copy.pdf >. Acesso em: $10 / 03 / 2016$.

EVANS, W.N e KESSIDES, I.A. "Localized Market Power in the Airline Industry. "Review of Economics and Statistics, 1993.

FÁVERO, L. P., BELFIORE, P., SILVA, F. L.,CHAN,B. L. Análise de dados : modelagem multivariada para a tomada de decisões./ Luiz Paulo Fávero ... [et al.]. - Rio de Janeiro: Elsevier- $4^{\text {a }}$ reimpressão, 2009.

FRANCIS, J. C. Investments: Analysis and Management. 5. ed. Nova York: McGraw-Hill, 1991.

FEIJO, C., CARVALHO, P. G.M. e RODRIGUEZ, M. S. Concentração Industrial $e$ Produtividade do Trabalho na Indústria de Transformação nos anos 90: Evidências Empíricas. Economia v.4 n.1, p.19-52, 2003.

FERREIRA,M. P., SANTOS, J. C. e REIS, N. R. A indústria de aviação civil: custos mercados e alianças. Caso de estudo $\mathrm{n}^{\circ}$ 9, GLOBAVANTAGE - Center of Research in Internacional Business \& Strategy, 2011.

FICONTEX. Alíquota Interna ICMS. http://www.fiscontex.com.br/legislacao/ICMS/aliquotainternaicms.htm. Acesso em : 06/10/2015.

GEORGE, K.; JOLL C. Organização industrial: crescimento e mudança estrutural. Rio de Janeiro: Zahar, 1983.

GHAZAVI, S. e CHERAGHALI, M. R. A study on the effect of internet on competitiveness and customer loyalty in insurance industry based on Porter competitive forces. Management Science Letters 3. P.2001-2006, 2013.

GHEMAWAT, P. A estratégia e o cenário dos negócios: texto e casos/Pankaj Guemawat. Trad. Nivaldo Montingelli Jr. Porto Alegre: Bookman, 2001.

GHEMAWAT, P. A estratégia e o cenário dos negócios/ Pankaj Guemawat. Trad Patrícia Lessa Flores da Cunha.- 2.ed.- Porto Alegre: Bookman, 2007.

GIACCHETTA, J. Estratégia Empresarial e Vantagem Competitiva na Produção de Cafés Especiais. 51 páginas. Dissertação- Mestrado Profissional em Sistemas de Produção na Agropecuária/ Universidade José do Rosário Vellano. Alfenas-MG, 2011.

GOLDSMITH, A. N. Linking IT Planning to Business Strategy. Long Range Planning. Vol. 24. N. 6 pp. 67 to $77,1991$.

GONÇALVES, M. S. Análise dos aspectos internos, do ambiente externo e elaboração de cenários como base para a definição das estratégias. 19 de dezembro de 2011. 115 páginas. 
Dissertação- Programa de Pós-Graduação em Engenharia da Produção da Universidade Federal de Santa Maria. Santa Maria- RS, 2011.

GOUlART, A. M. C. Evidenciação Contábil do Risco de Mercado por Insituições Financeiras no Brasil. 202 páginas. Dissertação - Universidade de São Paulo. São Paulo, 2003.

GRUNDY, T. Rethinking and reinventing Michael Porters five forces model. Strategic Change. 2006.

GUARANYS, M. P. Análise da Política Regulatória de Transporte Aéreo no Brasil. 138 páginas. Dissertação- Programa de Pós-Graduação em Direito/ Universidade de Brasília. Brasília, 2010.

HAIR,.J.H.J., ANDERSON, R.E. TATHAM, R.L. CLACK, W.C. trad. Adonai Schlup Sant'Ana e Anselmo Chaves Neto. Análise Multivariada de Dados. 5 ed. Porto Alegre: Bookman. 2005.

HOLANDA, S. F. B. Estrutura industrial no Brasil : concentração e diversificação. IPEA/INPES, 1983.

HOQUE, Z., CHIA, M. Competitive forces and the levers of control framework in a manufacturing setting. Subtitle A tale of a multinational subsidiary. Qualitative Research in Accounting \& Management, vol. 9 Iss 2 pp. 123-145, 2012.

INSTITUTO BRASILEIRO DE PLANEJAMENTO E TRIBUTAÇÃO. Combustível de avião tem mais imposto do que o de ônibus. http://www.ibpt.com.br/noticia/1500/Combustivel-de-aviao-tem-mais-impostos-do-que-o-deonibus. 2014. Acesso em: 06/10/2015.

JORION, P. Value at risk. Bolsa de Mercadorias \& Futuros, 1998.

JANÉ, D. de A. A Simulação de Monte Carlo e a Lógica Fuzzy na Análise Econômico/Financeira de Investimentos Sob Condições de Risco. 158 páginas. Dissertação Universidade Federal de Itajubá. Itajubá, 2003.

JOHSON, R.; WICHERN, D. W. Applied Multivariate Statistical Analysis. New Jersey: Prentice Hall International, Inc. 1988.

SARAIVA, A.F.J., TABOSA, C. de M. e COSTA, R.P. Simulação de Monte Carlo aplicada à análise econômica de pedido. Produção, 2011.

KARAGIANNOPOULOS, G.D., GEORGOPOULOS, N. e NIKOLOPOULOS, K. Fathoming Porter's Five forces model in the internet era. Emerald Group Publishing Limited. Vol.7 n $6,2005$.

KUPFER, D. e HASENCLEVER,L. Economia Industrial: Fundamentos teóricos e práticos no Brasil. $3^{\text {a }}$ Reimpressão.Rio de Janeiro: Elsevier,2002. 
LABINI, S. Oligopólio e Progresso Técnico. Ed. Universidade de São Paulo, São Paulo, 1980.

LATORRE, M.do R.D. de O. e CARDOSO, M.R.A. Análise de séries temporais em epidemiologia: uma introdução sobre os aspectos metodológicos. Revista brasileira Epidemiol, 2001.

LEVI, E.R. Análise do mercado e estimação das demandas de cana-de-açúcar, açúcar e etanol brasileiro. Monografia- Universidade Federal do Rio de Janeiro . Rio de Janeiro, 2009.

MACHADO, E.A., ALMEIDA, L.B. , GARCIAS,P.M. e BACARJI,A.G. Desempenho operacional-financeiro e concentração de mercado sob o enfoque do paradigma estruturaconduta-desempenho : a um estudo exploratório na indústria brasileira de laticínios no período de 1997 a 2006. Brazilian Business Review, 2010.

MARTIN, S. Industrial economics: economic analysis and public policy. New Jersey: Prentice Hall. Ed. 2, P. 623, 1993.

MARTINS, T.M. e MARTINELLI, D. P. Ciclos e previsão dos preços das commodities: um modelo de indicador antecedente para a commodity açúcar. Revista de Administração, Contabilidade e Economia da FUNDACE, 2010.

MASON, E. S. Price and Production Policies of Large-Scale Enterprise. American Economis Review. P. 61-64. 1939.

MELLO, F. O. T. Economia de Mercado, 2010.

MELO, D. B. Análise da rede de valor voltada para os negócios internacionais: estudo de caso da empresa líder do setor de calçados do Ceará . Junho de 2008. 152 páginas. Dissertação - Programa de Pós-Graduação em Administração/Universidade de Fortaleza. Fortaleza, 2009.

MENDONÇA, M.J. e SACHSIDA, A. Identificando a demanda e a oferta de crédito bancário no Brasil. Nota Técnica IPEA, 2013.

MIOTto, G. R. Análise dos Reflexos do Posicionamento Estratégico no Resultado de Companhias Aéreas Brasileiras no Período de 2001 a 2005. Revista Universo Contábil. Blumenau, 2008.

MORSE, W. J. e ROTH, H. P. "Cost Accounting: Processing, Evaluating, and Using CostData”. Addison Wesley Publishing Company. Ed. 3, 1986.

MORRISON S \& WINSTON, C. The Economic Effects of Airline Deregulation. Brookings Institution, Chap. 1,1986.

NAKAMURA, W.T., MARTIN, D.M.L., FORTE, D., FILHO, A.F.de C., COSTA, A.C.F. e AMARAL, A. C. Determinantes de estrutura de capital no mercado brasileiro - Análise de 
regressão com painel de dados no período 1999-2003. Revista Contabilidade Financeira, 2007.

NASCIMENTO, A. C., VIEIRA, W. da C. e BRAGA, M. J. Determinantes de Guerra de Preços e Conluio no Transporte Aéreo Brasileiro. Revista Economia Contemporânea. V. 15 n.3, p. 441-460. Rio de Janeiro, 2011.

NAYLOR, T. E.; BALINTFY, J.L.; BURDICK, D. S. e CRU, K. "Computer Simulation Techniques". Wiley \& Sons, 1966.

NETO, P. de M., ARAÚJO, L. A. D. e PONCE, D. A. S. Competição e concentração entre os bancos brasileiros. Congresso ANPEC, 2008.

NOVO, J. B. M., LAURO, L. C. D. J. Simulação Monte Carlo de mecanismo de transferência de energia de excitação eletrônica: modelo de Perrin para a supressão estática da luminescência. Química Nova. Vol. 34 nº 4, 707-709, 2011.

NOGUEIRA, M. A. Análise estrutural do setor de telefonia celular na cidade de São Paulo à luz do modelo de concorrência ampliada de Michael E. Porter. 18 de agosto de 2011.147 páginas. Dissertação- Programa de Mestrado em Administração da Universidade Municipal de São Caetano do Sul. São Caetano do Sul-SP, 2011.

O'CONNOR, N. G., VERA-MUÑOZ, S. C. e CHAN, F. Competitive forces and the importance of management control systems in emerging-economy firms: The moderating effect of international market orientation. Accounting, Organization and Society. Ed. 36, P. 246-266, 2011.

OLIVEIRA, A. V. M., SALGADO, L. H. Reforma Regulatória e Bem-Estar no Transporte Aéreo Brasileiro: E Se a Flexibilização dos Anos 1990 Não Tivesse Ocorrido? Documento de Trabalho N. 013 - Acervo Científico do Núcleo de Estudos em Competição e Regulação do Transporte Aéreo (NECTAR). São José dos Campos, SP. Disponível em www.nectar.ita.br,2006.

OLIVEIRA, A. V. M. Performance dos Regulados e Eficácia do Regulador: uma Avaliação das Políticas Regulatórias do Transporte aéreo e dos Desafios para o Futuro. IPEA. Rio de Janeiro, 2007.

OLIVEIRA. A.V.M. Estudos dos determinantes de preços das companhias aéreas no mercado doméstico. Rio de Janeiro: ANAC, 2009.

OLIVEIRA, A. V. M. E HUSE, C. (2005). Localized Competitive Advantage and Price Reactions to Entry: FullService vs. Low-Cost Airlines in the Brazilian Market. Documento de Trabalho N. 010 - Acervo Científico do Núcleo de Estudos em Competição e Regulação do Transporte Aéreo (NECTAR). São José dos Campos, SP. Disponível em Acesso em 12 jun 2006.

OLIVEIRA, I.A., CIRILLO, M.A. e BORGES, S.V. Estudos da não linearidade dos modelos de Oswin e Halsey aplicados na construção de isotermas. Revista Ceres, 2011. 
OLIVEIRA, R. F.; SCARPEL, R. A.; OLIVEIRA, A. V. M. de. Insolvência de Empresas e Crise: um estudo dos determinantes da saída de mercado de companhias aéreas. In: Simpósio de Transporte Aéreo , 7, 2008, Rio de Janeiro. Anais... Rio de Janeiro: SITRAER, 2008. CDROM.

PORTER, M. E. "Note on the Structural Analysis of Industries". Caso n. 376-054, Harvard Business School, Boston, 1975.

PORTER, M. E. How competitive forces shape strategy. Harvard Business Review, v. 57, n. 2, p. 137-145, 1979.

PULIDO, J. E.; JACOBS, T.L.; PRATES de L.,E.C. Structural reliability using Monte Carlo Simulation with variance reduction techniques on elastic-plastic structures. Computer and Structures. Páginas 419-430. 1992.

REIS, C.Q.M. Determinação do espectro de energia de radiação utilizados em Radioterapia a partir de medidas de atenuação e Simulação Monte Carlo. Dissertação - Universidade de São Paulo. Ribeirão Preto, 2010.

RESENDE, M.: BOFF, H. Concentração industrial. In: KUPFER, D.; OLIVEIRA, R. F.; SCARPEL, R. A.; OLIVEIRA, A. V. M.. Insolvência de Empresas e Crise: um estudo dos determinantes da saída de mercado de companhias aéreas. In: Simpósio de Transporte Aéreo, Rio de Janeiro. Anais SITRAER, 2008.

RINGLAND, G.A. Approaches to hnowledge Representation: An introduction, G.A. Ringland and Duce, D.A., eds. (John Wiley and Sons Inc., New York, 1988.

ROBINSON, J. The Economics of Imperfect Competition. London : Macmillan, 1933.

ROCHA, C.H.; SOUSA, R.R.C. e CAMPOS, N.S. Uma análise da situação financeira da indústria brasileira de aviação civil. The Journal of Transport Literature. Pág. 35-39. 2016.

ROCHA, F. Dinâmica da concentração de mercado na indústria brasileira. Economia e Sociedade. V.19, n.3, 2010.

RODRIGUES, R. A. O Mercado de Aviação Doméstica no Brasil: o processo de desregulação comparado com a experiência norte-americana, sob o enfoque da Teoria Política Positiva da Regulação. Dissertação de Mestrado em Economia da Regulação. Brasília: Universidade de Brasília, Brasília, 2003.

RUNWAY NEWS.< http://www.runwaynew.pt/news/aviacao-domestica-no-brasil-perde-4da-procura-em-janeiro>. Acesso em: 10/03/2016.

SAC (Secretaria de Aviação Civil).< http://www.aviacao.gov.br/assuntos/concessoes-deaeroporto>. Acesso em: 12/11/2015.

SALGADO, L.H. \& OLIVEIRA, A. V. M. “A Reforma Regulatória da Década de 1990 no Transporte Aéreo Brasileiro e suas Implicações no Bem-Estar", projeto "Revisão da Regulação do Setor de Transporte Aéreo Brasileiro", REDIPEA/PNUD, IPEA, mimeo. 2006. 
SALGADO, L. H. Tópicos sobre regulação na aviação civil. Simpósio de Transporte Aéreo. Anais Sitraer 7 XC-XCVIII. 2008.

SALGADO, L.H. e GUIMARÃES, E.A. (2003) "A Regulação do Mercado de Aviação Civil no Brasil", Nota Técnica n.2, IPEA.

SALGADO, L. H.; VASSALLO, M. D.; OLIVEIRA, A. V. M. Regulação, políticas setoriais, competitividade e formação de preços: considerações sobre o transporte aéreo no Brasil. Journal of Transport Literature, vol. 4, n.1, p. 7-48, 2010.

SÁNCHEZ, M.S.A.Verificação 3D da distribuição da dose em radiocirurgia estereotáxica através de simulação Monte Carlo e dosimetria por ressonância magnética nuclear. Tese Universidade de São Paulo. Ribeirão Preto, 2012.

SANTOS, A. M. A., SOUSA, E. A., JACINTO, P.de A. e TEJADA, C.A.O. Elasticidade preço e renda das exportações e importações: uma abordagem através de dados em painel para os Estados do Brasil. Análise: a Revista Acadêmica da FACE, 2011.

SECURATO, J. R. Decisões financeiras em condições de risco. São Paulo: Atlas, 1996

RAMSEY, F. P. A mathematical theory of saving. The Economic Journal, v.38, n.152, p.54359, dec. 1928.

SCHARPENSEEL, M.F. Consequences of E.U. Airline Deregulation in the Context of the Global Aviation Market. Northwest Journal of Internacional Law \& Business. 2001.

SCHWARTZ, S. H. Basic human values: Theory, measurement, and applications. Revue française de sociologie, 2006.

SIGNOR, R. Análise de regressão do consumo de energia elétrica frente a variáveis arquitetônicas para edifícios comerciais climatizados em 14 capitais brasileiras. Dissertação Universidade Federal de Santa Catarina. Florianópolis, 1999.

SILVA, A.L da L. Concentração e desempenho competitivo no complexo industrial de papel e celulose entre 1987-1996. Florianópolis: UFSC, 1998.

SILVA, A.M. e CIRILLO, M.A. Estudo por simulação Monte Carlo de um estimador robusto utilizado na inferência de um modelo binomial contaminado.Maringá, 2010.

SILVA, R. G., LIMA, J. E. Valoração Contingente do Parque "Chico Mendes uma Aplicação Probabilística do Método Referendum com Building Games”. RER. 2004.

SLATER, A. F. e OLSON, E. M. A fresh look at industry and market analysis. Business Horizons, 2002.

SMITH Jr., F. L. and COX, B. Airline deregulation. The Concise Encyclopedia of Economics. Library of Economics and Liberty. http://www.econlib.org/library/Enc/AirlineDeregulation.html. (2008). Acesso em: 05/10/2015. 
SONG, M., CALANTONE, R. J. e BENEDETTO, A. D.Competitive Forces and Strategic Choice Decisions: an Experimental Investigation in the United States and Japan. Strategic Management Journal. Strat. Mgmt. J., 23: 969-978, 2002.

SOUZA, B.A., OLIVEIRA, C.A.C., SANTAN, J.C.O., NETO, L.A. da C.V. e SANTOS, D. de G. Análise dos indicadores PIB nacional e PIB da Indústria da construção civil. Revista de Desenvolvimento Econômico, 2015.

SOUZA, J. G. de M., ALMEIDA, A. N. SOUSA, R. R.C. CAMPOS, N. de S. e ALMEIDA, A. R. S. dos S. M. Incerteza da Viabilidade Econômica de um Projeto Portuário: Uma Aplicação da Simulação Monte Carlo. Revista Eletrônica Gestão \& Saúde. V.6 p.1042-56, 2015.

SPIEGEL, M. R. Estatística. São Paulo: Makron Books, 1993.

TABACHNIK, B., e FIDELL, L. S. Using multivariate statistics (3a ed.). New York: Harper Collins, 1996.

TAVITIYAMAN, P., QU, H., ZHANG, H. Q. The impact of industry force factors on resource competitive strategies and hotel performance. Internacional Journal of Hospital Management, 2010.

ULTREMARE, F.O. Impactos da produção e dos preços do agronegócio nos padrões de consumo no Brasil.Dissertação - Universidade de São Paulo. Piracicaba, 2012.

VASCONCELLOS, M. A. S. \& Garcia, M. E. Fundamentos de Economia. São Paulo: Saraiva, 2004.

TAVARES, S.M. e GIMENES, S. P. Teoria da demanda e equilíbrio de mercado. Faculdade de Tecnologia de Sorocaba. São Paulo, 2012.

VAN DER HEJIDEN, H. "User Acceptance of Hedonic Information Systems," MIS Quarterly, (28: 4), 2004.

VASCONCELLOS, Marco Antônio S.; GARCIA, Manoel E. Fundamentos de Economia. 2. ed. São Paulo: Saraiva, 2004.

ZOHARABI, A. Formulating and Ranking Qualitative Strategies and Studying the Five Competitive Forces of Porter in Industrial Organizations. Advances in Environmental Biology, 7(8): 1731-1744 2013.

WINDLE,R.,DRESNER, M. The short and long run effects of entry on US domestic air routes. Transportation .pp. 14-25, 1995.

WINNISCHOFER, H., ARAÚJO, M. P., JÚNIOR, L. C. D. e NOVO, J. B.M. Simulação Monte Carlo no ensino de luminescência e cinética de decaimento de estados excitados.Química Nova, vol. 33 , nº 1, 225-228, 2010. 


\section{ANEXO I}

Para ilustrar a afirmação realizada anteriormente, considere uma companhia aérea pequena em início de operação no período T. Levando em conta 100 assentos quilômetros ofertados (ASK) e uma demanda (RPK) de 50 passageiros.

\begin{tabular}{|c|c|c|c|c|}
\hline $\begin{array}{c}\text { Companhia } \\
\text { aérea }\end{array}$ & $\begin{array}{c}\text { Oferta } \\
\text { (ASK) }\end{array}$ & $\begin{array}{c}\text { Demanda } \\
\text { pagante (RPK) }\end{array}$ & $\begin{array}{c}\text { Taxa de } \\
\text { aproveitamento } \\
\text { (RPK/ASK) }\end{array}$ & $\begin{array}{c}\text { Oferta ociosa } \\
\text { (ASK-RPK) }\end{array}$ \\
\cline { 2 - 5 } & 100 & 50 & 0,5 & 50 \\
\hline
\end{tabular}

Levando em conta a equação (RPK/ASK) atualmente utilizada pela Agência Nacional de Aviação Civil (ANAC) para medir o aproveitamento, há uma taxa equivalente a 0,5 bem como a quantidade de 50 assentos ociosos.

Considerando um instante T', a mesma empresa oferece 1.000 assentos e capta uma demanda de 800 passageiros pagantes.

\begin{tabular}{|c|c|c|c|c|}
\hline $\begin{array}{c}\text { Companhia } \\
\text { aérea }\end{array}$ & $\begin{array}{c}\text { Oferta } \\
\text { (ASK) }\end{array}$ & $\begin{array}{c}\text { Demanda pagante } \\
\text { (RPK) }\end{array}$ & $\begin{array}{c}\text { Taxa de } \\
\text { aproveitamento } \\
\text { (RPK/ASK) }\end{array}$ & $\begin{array}{c}\text { Oferta } \\
\text { ociosa } \\
\text { (ASK-RPK) }\end{array}$ \\
\cline { 2 - 6 } & 1.000 & 800 & 0,8 & \\
\hline
\end{tabular}

Aplicando a mesma análise é possível perceber que no instante T' a empresa obteve um aumento de $30 \%$ na sua taxa de aproveitamento em relação ao instante T, porém a quantidade de capacidade ociosa foi $300 \%$ maior.

Esse exemplo mostra que a equação utilizada atualmente para medir a evolução do aproveitamento da oferta de assentos pode passar uma ideia equivocada da real evolução do aproveitamento. Desse modo seria mais adequado quantificar percentualmente a evolução da ociosidade ao invés de usar a taxa de aproveitamento.

http://bibliotecadigital.fgv.br/ojs/index.php/rbe/article/viewArticle/657

\section{ANEXO II}

Estas são as variáveis testadas. Para cada simulação foi testado um dos 8 principais intervalo de tarifa área para verificar se há significância estatística para afirmar que se trata de uma variável explicativa do lucro líquido da indústria.

\begin{tabular}{|l|r|}
\hline Excesso de Capacidade & X1 \\
\hline Participação percentual do combustível no custo & X2 \\
\hline Receita de voo & X3 \\
\hline Volatilidade da tarifa aérea mensal & X4 \\
\hline Percentual de compras de bilhetes por intervalo de tarifa & X5 \\
\hline
\end{tabular}

Simulações

\begin{tabular}{|c|l|}
\hline RESUMO DOS RESULTADOS & \\
\hline Estatística de regressão & \\
\hline
\end{tabular}




\begin{tabular}{|c|c|c|c|c|c|}
\hline R múltiplo & 0,984352414 & & & & \\
\hline R-Quadrado & 0,968949674 & & & & \\
\hline R-quadrado ajustado & 0,937899348 & & & & \\
\hline Erro padrão & 527331315,6 & & & & \\
\hline Observações & 11 & & & & \\
\hline \multicolumn{6}{|l|}{ ANOVA } \\
\hline & $g l$ & $S Q$ & $M Q$ & $F$ & F de significação \\
\hline Regressão & 5 & $4,33883 E+19$ & $8,68 \mathrm{E}+18$ & 31,20578 & 0,000892403 \\
\hline Resíduo & 5 & $1,39039 \mathrm{E}+18$ & $2,78 \mathrm{E}+17$ & & \\
\hline \multirow[t]{2}{*}{ Total } & 10 & $4,47786 \mathrm{E}+19$ & & & \\
\hline & Coeficientes & Erro padrão & Stat $t$ & valor- $P$ & 95\% inferiores \\
\hline Interseção & 43.346.731.400,61 & 5322000155 & 8,14482 & 0,000453 & 29666094479 \\
\hline Variável X 1 & - 30.158.689.352,06 & 7438212837 & $-4,05456$ & 0,009781 & -49279224154 \\
\hline Variável X 2 & $776.573 .018,40$ & 81157579,39 & $-9,56871$ & 0,000211 & $-985195217,7$ \\
\hline Variável X 3 & 0,30 & 0,07932101 & $-3,74038$ & 0,013426 & $-0,500592096$ \\
\hline Variável X 4 & $28.787 .619,05$ & 13885699,03 & $-2,07318$ & 0,092863 & $-64481944,75$ \\
\hline$>0,00$ e $<100,00$ & 8.685.365.396,81 & 6531686394 & 1,329728 & 0,24104 & -8104868998 \\
\hline
\end{tabular}

\begin{tabular}{|c|c|c|c|c|c|}
\hline \multicolumn{2}{|l|}{ RESUMO DOS RESULTADOS } & & & & \\
\hline \multicolumn{2}{|l|}{ Estatística de regressão } & & & & \\
\hline R múltiplo & 0,982156709 & & & & \\
\hline R-Quadrado & 0,964631802 & & & & \\
\hline R-quadrado ajustado & 0,929263604 & & & & \\
\hline Erro padrão & 562803706,3 & & & & \\
\hline Observações & 11 & & & & \\
\hline \multirow[t]{2}{*}{ ANOVA } & \multirow[b]{2}{*}{$g l$} & & & & \\
\hline & & $S Q$ & $M Q$ & $F$ & F de significação \\
\hline Regressão & 5 & $4,31949 \mathrm{E}+19$ & $8,64 \mathrm{E}+18$ & 27,27399 & 0,001229906 \\
\hline Resíduo & 5 & $1,58374 \mathrm{E}+18$ & $3,17 \mathrm{E}+17$ & & \\
\hline \multirow[t]{2}{*}{ Total } & 10 & $4,47786 \mathrm{E}+19$ & & & \\
\hline & Coeficientes & Erro padrão & Stat $t$ & valor- $P$ & 95\% inferiores \\
\hline Interseção & 40409284358 & 6868455648 & 5,883314 & 0,002015 & 22753357036 \\
\hline Variável X 1 & -27517843232 & 9881204799 & $-2,78487$ & 0,038679 & -52918288793 \\
\hline Variável X 2 & -768243912 & 86760107,12 & $-8,85481$ & 0,000305 & $-991267867,4$ \\
\hline Variável X 3 & $-0,258655859$ & 0,095943131 & $-2,69593$ & 0,042993 & $-0,505285528$ \\
\hline Variável X 4 & $-17839412,4$ & 24091226,44 & $-0,74049$ & 0,492286 & $-79767881,47$ \\
\hline$>=100,00 \mathrm{e}<200,00$ & 4661200340 & 4802825470 & 0,970512 & 0,376365 & -7684855568 \\
\hline
\end{tabular}

\begin{tabular}{|l|r|}
\hline \multicolumn{2}{|c|}{ RESUMO DOS RESULTADOS } \\
\hline Estatística de regressão & \\
\hline R múltiplo & 0,979382937 \\
\hline
\end{tabular}

Página 96 


\begin{tabular}{|c|c|c|c|c|c|}
\hline R-Quadrado & 0,959190937 & & & & \\
\hline R-quadrado ajustado & 0,918381874 & & & & \\
\hline Erro padrão & 604545222,4 & & & & \\
\hline Observações & 11 & & & & \\
\hline \multicolumn{6}{|l|}{ ANOVA } \\
\hline & $g l$ & $S Q$ & $M Q$ & $F$ & $F$ de significação \\
\hline Regressão & 5 & $4,29513 \mathrm{E}+19$ & $8,59 E+18$ & 23,50436 & 0,001748365 \\
\hline Resíduo & 5 & $1,82737 \mathrm{E}+18$ & $3,65 E+17$ & & \\
\hline \multirow[t]{2}{*}{ Total } & 10 & $4,47786 \mathrm{E}+19$ & & & \\
\hline & Coeficientes & Erro padrão & Stat $t$ & valor- $P$ & 95\% inferiores \\
\hline Interseção & 42905763901 & 6940259347 & 6,182156 & 0,001614 & 25065259294 \\
\hline Variável X 1 & -32922005831 & 8309458297 & $-3,96199$ & 0,010722 & -54282148385 \\
\hline Variável X 2 & $-740762530,8$ & 87114248,49 & $-8,50335$ & 0,00037 & $-964696835,5$ \\
\hline Variável X 3 & $-0,281750735$ & 0,10573861 & $-2,6646$ & 0,044637 & $-0,553560486$ \\
\hline Variável X 4 & $-32711048,18$ & 18681318,52 & $-1,751$ & 0,140341 & $-80732906,2$ \\
\hline$>=200,00$ e $<300,00$ & 1973425954 & 5100615382 & 0,3869 & 0,71475 & -11138123293 \\
\hline
\end{tabular}

\begin{tabular}{|c|c|c|c|c|c|}
\hline \multicolumn{2}{|l|}{ RESUMO DOS RESULTADOS } & & & & \\
\hline \multicolumn{2}{|l|}{ Estatística de regressão } & & & & \\
\hline R múltiplo & \multirow{2}{*}{$\begin{array}{r}0,97876648 \\
0,957983822\end{array}$} & & & & \\
\hline R-Quadrado & & & & & \\
\hline R-quadrado ajustado & 0,915967644 & & & & \\
\hline Erro padrão & 613421163,5 & & & & \\
\hline Observações & 11 & & & & \\
\hline \multicolumn{6}{|l|}{ ANOVA } \\
\hline & $g l$ & $S Q$ & $M Q$ & $F$ & F de significação \\
\hline Regressão & 5 & $4,28972 \mathrm{E}+19$ & $8,58 \mathrm{E}+18$ & 22,80036 & 0,001878036 \\
\hline Resíduo & 5 & $1,88143 \mathrm{E}+18$ & $3,76 \mathrm{E}+17$ & & \\
\hline \multirow[t]{2}{*}{ Total } & 10 & $4,47786 \mathrm{E}+19$ & & & \\
\hline & Coeficientes & Erro padrão & Stat $t$ & valor-P & 95\% inferiores \\
\hline Interseção & 44.120.697.273,25 & 6572558806 & 6,712865 & 0,001111 & 27225396999 \\
\hline Variável X 1 & - 33.906.382.765,20 & 8045757917 & $-4,21419$ & 0,008374 & -54588661913 \\
\hline Variável X 2 & $736.805 .031,08$ & 88347767,51 & $-8,33983$ & 0,000405 & $-963910197,4$ \\
\hline Variável X 3 & 0,30 & 0,093885278 & $-3,21634$ & 0,023561 & $-0,543306983$ \\
\hline Variável X 4 & $37.405 .166,30$ & 14353941,45 & $-2,60592$ & 0,047906 & $-74303147,45$ \\
\hline$>=300,00 \mathrm{e}<400,00$ & $330.977 .469,27$ & 7930430863 & 0,041735 & 0,968325 & -20054844048 \\
\hline
\end{tabular}

\begin{tabular}{|l|r|}
\hline RESUMO DOS RESULTADOS & \\
\hline Estatística de regressão & \\
\hline R múltiplo & 0,9794586 \\
\hline R-Quadrado & 0,959339149 \\
\hline
\end{tabular}

Página 97 


\begin{tabular}{|c|c|c|c|c|c|}
\hline R-quadrado ajustado & 0,918678299 & & & & \\
\hline Erro padrão & 603446416,2 & & & & \\
\hline Observações & 11 & & & & \\
\hline \multicolumn{6}{|l|}{ ANOVA } \\
\hline & $g l$ & $S Q$ & $M Q$ & $F$ & Fde significação \\
\hline Regressão & 5 & $4,29579 E+19$ & $8,59 E+18$ & 23,59368 & 0,001732817 \\
\hline Resíduo & 5 & $1,82074 \mathrm{E}+18$ & $3,64 \mathrm{E}+17$ & & \\
\hline \multirow[t]{2}{*}{ Total } & 10 & $4,47786 E+19$ & & & \\
\hline & Coeficientes & Erro padrão & Stat $t$ & valor- $P$ & 95\% inferiores \\
\hline Interseção & 43.714.646.669,58 & 6167073477 & 7,088394 & 0,000865 & 27861679617 \\
\hline Variável X 1 & - 35.465.569.153,34 & 8693081646 & $-4,07975$ & 0,009542 & -57811846920 \\
\hline Variável X 2 & $740.249 .356,67$ & 86786023,09 & $-8,52959$ & 0,000365 & $-963339931,1$ \\
\hline Variável X 3 & 0,29 & 0,100218118 & $-2,84538$ & 0,036018 & $-0,54277767$ \\
\hline Variável X 4 & $37.392 .015,53$ & 14022237,68 & $-2,66662$ & 0,044529 & -73437325 \\
\hline$>=400,00 \mathrm{e}<500,00$ & $5.158 .096 .506,46$ & 12567186021 & 0,410442 & 0,698478 & -27146883592 \\
\hline
\end{tabular}

\begin{tabular}{|c|c|c|c|c|c|}
\hline \multirow{2}{*}{\multicolumn{2}{|c|}{$\begin{array}{l}\text { RESUMO DOS RESULTADOS } \\
\text { Estatística de rearessão }\end{array}$}} & & & & \\
\hline & & & & & \\
\hline R múltiplo & \multirow{2}{*}{$\begin{array}{l}0,981103933 \\
0,962564927\end{array}$} & & & & \\
\hline R-Quadrado & & & & & \\
\hline R-quadrado ajustado & 0,925129854 & & & & \\
\hline Erro padrão & 579015013,4 & & & & \\
\hline Observações & 11 & & & & \\
\hline \multirow[t]{2}{*}{ ANOVA } & \multirow[b]{2}{*}{$g l$} & \multirow[b]{2}{*}{$S Q$} & \multirow[b]{2}{*}{$M Q$} & \multirow[b]{2}{*}{$F$} & \multirow[b]{2}{*}{ F de significação } \\
\hline & & & & & \\
\hline Regressão & 5 & $4,31024 \mathrm{E}+19$ & $8,62 \mathrm{E}+18$ & 25,71292 & 0,001414328 \\
\hline Resíduo & 5 & $1,67629 \mathrm{E}+18$ & $3,35 \mathrm{E}+17$ & & \\
\hline \multirow[t]{2}{*}{ Total } & 10 & $4,47786 \mathrm{E}+19$ & & & \\
\hline & Coeficientes & Erro padrão & Stat $t$ & valor- $P$ & 95\% inferiores \\
\hline Interseção & $42.987 .556 .693,21$ & 6008084805 & 7,154952 & 0,000829 & 27543283033 \\
\hline Variável X 1 & - 29.954.555.292,97 & 9103110737 & $-3,29058$ & 0,0217 & -53354846393 \\
\hline Variável X 2 & $771.077 .081,96$ & 93566856,56 & $-8,24092$ & 0,000429 & -1011598344 \\
\hline Variável X 3 & 0,26 & 0,105794151 & $-2,41515$ & 0,060478 & $-0,527461669$ \\
\hline Variável X 4 & 27.427.339,66 & 18587508,45 & $-1,47558$ & 0,200078 & $-75208051,24$ \\
\hline$>=500,00 \mathrm{e}<600,00$ & - $\quad 4.895 .472 .563,74$ & 6248433308 & $-0,78347$ & 0,468818 & -20957581720 \\
\hline
\end{tabular}

\begin{tabular}{|l|r|}
\hline \multicolumn{1}{|c|}{ Estatística de regressão } & \\
\hline R múltiplo & 0,981428712 \\
\hline R-Quadrado & 0,963202317 \\
\hline R-quadrado ajustado & 0,926404633 \\
\hline Erro padrão & 574064539,6 \\
\hline
\end{tabular}

Página 98 


\begin{tabular}{|c|c|c|c|c|c|}
\hline Observações & 11 & & & & \\
\hline \multicolumn{6}{|l|}{ ANOVA } \\
\hline & $g l$ & $S Q$ & $M Q$ & $F$ & $F$ de significação \\
\hline Regressão & 5 & $4,31309 E+19$ & $8,63 E+18$ & 26,17562 & 0,001355842 \\
\hline Resíduo & 5 & $1,64775 \mathrm{E}+18$ & $3,3 E+17$ & & \\
\hline \multirow[t]{2}{*}{ Total } & 10 & $4,47786 E+19$ & & & \\
\hline & Coeficientes & Erro padrão & Stat $t$ & valor-P & 95\% inferiores \\
\hline Interseção & $43.398 .891 .401,40$ & 5831063923 & 7,442705 & 0,00069 & 28409664403 \\
\hline Variável X 1 & $-32.108 .010 .555,28$ & 7791340754 & $-4,12099$ & 0,009165 & -52136289565 \\
\hline Variável X 2 & $721.630 .379,96$ & 84294548,6 & $-8,56082$ & 0,000358 & $-938316415,4$ \\
\hline Variável X 3 & 0,31 & 0,086443967 & $-3,56406$ & 0,016145 & $-0,53030279$ \\
\hline Variável X 4 & 29.345.761,79 & 16458123,42 & $-1,78306$ & 0,134664 & $-71652714,88$ \\
\hline$>=600,00 \mathrm{e}<700,00$ & - 9.021.557.592,35 & 10698574763 & $-0,84325$ & 0,437558 & -36523119534 \\
\hline
\end{tabular}

\begin{tabular}{|c|c|c|c|c|c|}
\hline \multicolumn{2}{|l|}{ RESUMO DOS RESULTADOS } & & & & \\
\hline \multicolumn{2}{|l|}{ Estatística de regressão } & & & & \\
\hline $\mathrm{R}$ múltiplo & 0,98258268 & & & & \\
\hline R-Quadrado & 0,965468724 & & & & \\
\hline R-quadrado ajustado & 0,930937448 & & & & \\
\hline Erro padrão & 556104995 & & & & \\
\hline Observações & 11 & & & & \\
\hline \multirow[t]{2}{*}{ ANOVA } & \multirow[b]{2}{*}{$g l$} & \multirow[b]{2}{*}{$S Q$} & \multirow[b]{2}{*}{$M Q$} & \multirow[b]{2}{*}{$F$} & \multirow[b]{2}{*}{ F de significação } \\
\hline & & & & & \\
\hline Regressão & 5 & $4,32324 \mathrm{E}+19$ & $8,65 E+18$ & 27,95925 & 0,001159499 \\
\hline Resíduo & 5 & $1,54626 \mathrm{E}+18$ & $3,09 \mathrm{E}+17$ & & \\
\hline \multirow[t]{2}{*}{ Total } & 10 & $4,47786 \mathrm{E}+19$ & & & \\
\hline & Coeficientes & Erro padrão & Stat $t$ & valor- $P$ & 95\% inferiores \\
\hline Interseção & $42.388 .331 .833,34$ & 5839924870 & 7,258369 & 0,000776 & 27376327046 \\
\hline Variável X 1 & - 29.357.718.100,18 & 8478768229 & $-3,4625$ & 0,017994 & -51153085690 \\
\hline Variável X 2 & $765.222 .281,82$ & 84101666,96 & $-9,09878$ & 0,000268 & $-981412499,2$ \\
\hline Variável X 3 & 0,25 & 0,097316448 & $-2,57572$ & 0,049689 & $-0,50081964$ \\
\hline Variável X 4 & 25.915.300,51 & 17030241,07 & $-1,52172$ & 0,188566 & $-69692928,85$ \\
\hline$>=700,00 \mathrm{e}<800,00$ & - 11.793.727.117,16 & 11317619811 & $-1,04207$ & 0,345121 & -40886595016 \\
\hline
\end{tabular}

